\title{
DISTRIBUIÇÃO E CRESCIMENTO RADICULAR EM SOQUEIRAS DE CANA-DE-AÇÚCAR: DOIS CULTIVARES EM SOLOS COM CARACTERÍSTICAS DISTINTAS
}

\author{
MIRIAN CRISTINA GOMES COSTA
}

Tese apresentada à Escola Superior de Agricultura

“Luiz de Queiroz”, Universidade de São Paulo, para obtenção do título de Doutor em Agronomia, Área de Concentração: Solos e Nutrição de Plantas.

P I R A C I C A B A

Estado de São Paulo - Brasil

Julho - 2005 


\title{
DISTRIBUIÇÃO E CRESCIMENTO RADICULAR EM SOQUEIRAS DE CANA-DE-AÇÚCAR: DOIS CULTIVARES EM SOLOS COM CARACTERÍSTICAS DISTINTAS
}

\author{
MIRIAN CRISTINA GOMES COSTA \\ Engenheiro Agrônomo
}

Orientador: Prof. Dr. GODOFREDO CESAR VITTI

\begin{abstract}
Tese apresentada à Escola Superior de Agricultura
"Luiz de Queiroz", Universidade de São Paulo, para obtenção do título de Doutor em Agronomia, Área de Concentração: Solos e Nutrição de Plantas.
\end{abstract}

P I R A C I C A B A

Estado de São Paulo - Brasil

Julho de 2005 
Dados I nt er naci onai s de Cat al ogação na Publ i cação ( CI P) DI VI SÃO DE BI BLI OTECA E DOCUMENTAÇÃO - ESALQI USP

Costa, Mirian Cristina Gomes

Distribuição e crescimento radicular em soqueiras de cana-de-açúcar: dois cultivares em solos com características distintas / Mirian Cristina Gomes Costa. - Piracicaba, 2005.

$88 \mathrm{p.}$ : il.

Tese (Doutorado) - - Escola Superior de Agricultura Luiz de Queiroz, 2005.

Bibliografia.

1. Cana-de-açúcar 2. Caracterização do solo 3. Classificação do solo 4. Sistema radicular 5. Soca I. Título

CDD 633.61 
À Deus, meu mestre e senhor

\section{OFEREÇO}

Aos meus pais,

Maria e Erasmo, responsáveis pelo o que há de melhor em mim;

Aos meus irmãos e irmãs

Célia, Valter, Selma, Erasmo e Márcia, cujos bons exemplos sempre hei de seguir;

Aos meus cunhados, cunhadas, sobrinhos e sobrinhas que fazem parte de uma de minhas maiores riquezas: a família

DEDICO

"Aquele que ama a sabedoria, ama a vida...Ela o cumula de alegria, desvenda-lhe seus segredos e enriquece-o com tesouros de ciência, de inteligência e de justiça..."

(Eclo 4, 13. 20-21) 


\section{AGRADECIMENTOS}

Aos Professores Dr. Jairo Antônio Mazza e Dr. Godofredo Cesar Vitti, pela orientação;

Ao Professor Dr. Zed Rengel, pela orientação durante o estágio de doutorado no exterior (The University of Western Australia);

Ao Pesquisador Dr. Lúcio André de Castro Jorge (Embrapa-CNPDIA) e à Professora Dra. Maria de Fátima Guimarães (CCA/UEL), pelos esclarecimentos metodológicos;

Aos Professores Dr. Álvaro Pires da Silva, Dr. Paulo Cesar Ocheuze Trivelin e Dr. Edgar Gomes Ferreira de Beauclair, pelas críticas e sugestões apresentadas no exame de qualificação;

Ao Professor Dr. Márcio Rodrigues Lambais e à sua equipe de pós-graduandos, pelo auxílio que viabilizou a execução de testes enzimáticos;

À Márcia Maria Gomes Costa e Ari Santos da Costa, pelas correções gramaticais;

Ao Programa de Pós-graduação em Solos e Nutrição de Plantas, pela oportunidade de treinamento;

À FAPESP pela concessão de bolsa de doutorado de 10/2002 à 08/2004 e 02/2005 à 07/2005;

À CAPES pela concessão de bolsa de doutorado e de estágio de doutorando no exterior (PDEE) nos períodos de 03/2002 à 09/2002 e 09/2004 à 02/2005, respectivamente;

Ao Departamento de Solos e Nutrição de Plantas da ESALQ/USP, à School of Earth and Agricultural Sciences e à School of Plant Biology (FNAS/UWA), pela infraestrutura de trabalho; 
Ao Grupo COSAN - Unidade Rafard, pela concessão das áreas experimentais e suporte de campo;

Aos colegas Alasdair Grigg e Paul Damon, pelo auxílio em procedimentos laboratoriais;

Aos colegas Tairone Paiva Leão, Aline Marques Genú, Emmanuel Mapfumo e Zlatko Svecnjak , pelo auxílio nas análises estatísticas;

A todos estagiários, componentes do GAPE e supervisionados, pela preciosa ajuda nas difíceis avaliações de campo;

Aos técnicos Jair Ferrer da Silva e Dorival Grisotto, além de técnicos e funcionários do Grupo COSAN, que participaram ativamente das avaliações de campo;

À Isabela Rodrigues Bologna, pela amizade e dedicação para resolver aspectos burocráticos durante o tempo em que estive fora do país;

Aos funcionários, professores e colegas de pós-graduação dos Departamentos de Solos e Nutrição de Plantas da ESALQ/USP, Soil Science e Plant Biology da FNAS/UWA, pelo agradável convívio e amizade;

Ao grupo de pesquisa do Professor Dr. Zed Rengel, pela receptividade, interesse em meu trabalho de pesquisa e discussões científicas que muito contribuíram com minha formação;

Aos colegas Michelle Naraze Xavier, Carlos Eduardo Faroni e Sérgio Luis de Miranda Mello, pelas discussões científicas a respeito do estudo de raízes;

Aos amigos Isabela Bologna, Aline Genú, Flávia Morales, Tiago Osório, Valdomiro Severino, Luis Rodriguez, Ana Carla \& Paul, Roberta Marra \& Francesco, Eleftheria Dalmaris, Werther Guidi, Pachi Baquedano, Wasantha Maduraperuma, Emielda Baiq, Tatjana Balint, Ksenija Stanic-Colic, James Easton, Paul Damon, YaminMa, e todos os outros que estiveram ao meu lado e me apoiaram;

A todos aqueles que fizeram, que fazem e que ainda farão parte de minha vida, contribuindo com meu crescimento pessoal e profissional, 


\section{SUMÁRIO}

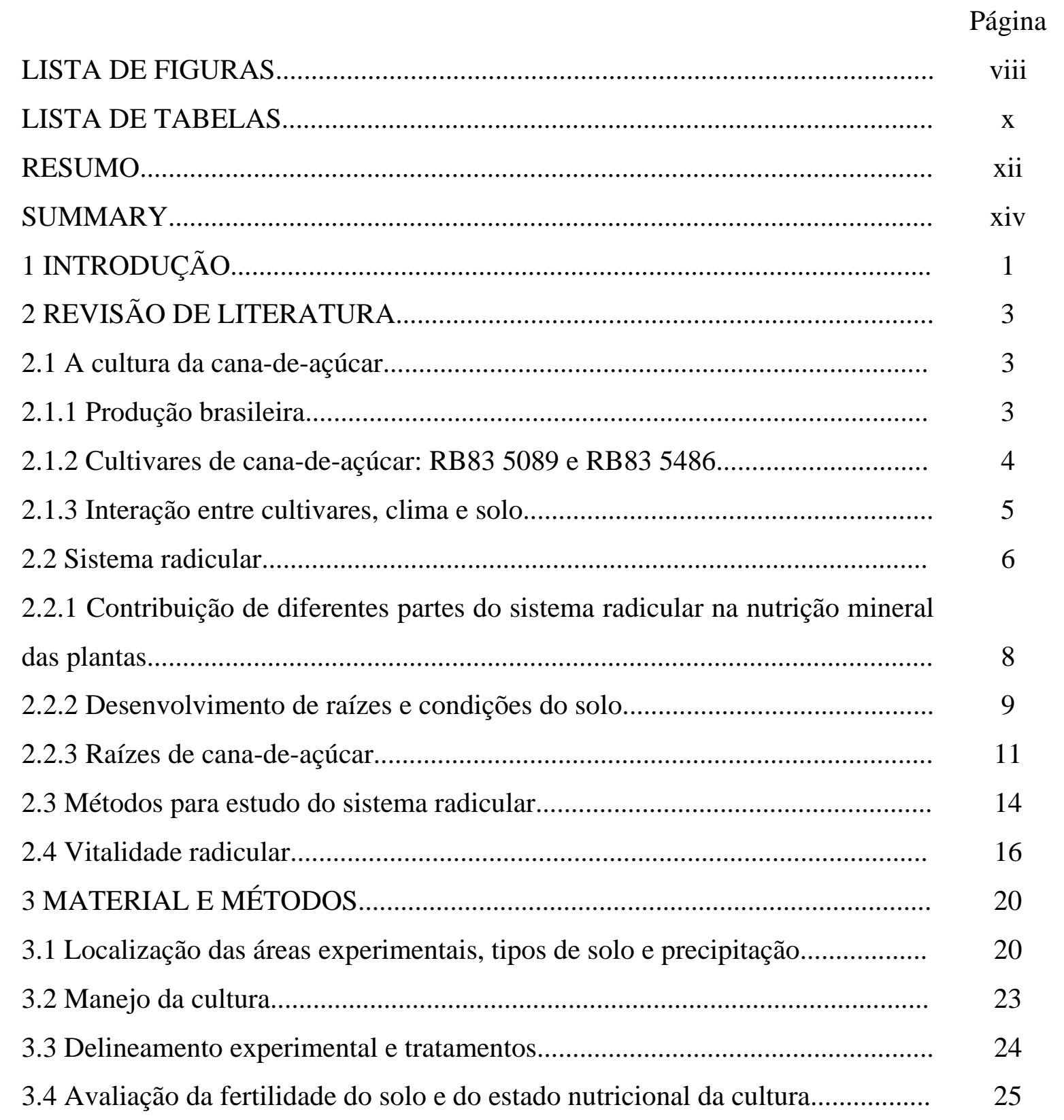


3.5 Curva de retenção de água, macroporosidade, densidade do solo e resistência à penetração (RP)............................................................................. 25

3.6 Avaliação da distribuição do sistema radicular................................................. 26

3.7 Dinâmica radicular a partir da brotação das soqueiras...................................... 29

3.8 Análises estatísticas........................................................................................ 30

4 RESULTADOS E DISCUSSÃO................................................................... 31

4.1 Avaliação da fertilidade do solo e do estado nutricional da cultura................... 31

4.1.1 Fertilidade do solo - Atributos químicos........................................................ 31

4.1.2 Estado nutricional da cultura - Teor foliar, conteúdo e extração por

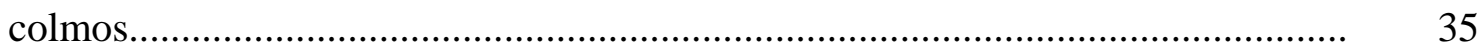

4.2 Curva de retenção de água, densidade, resistência à penetração e porosidade

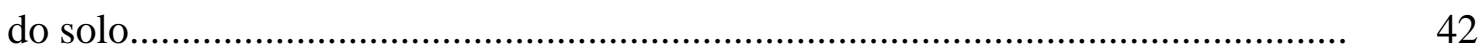

4.3 Avaliação da distribuição do sistema radicular.................................................. 46

4.4 Avaliação da renovação do sistema radicular a partir da brotação de soqueiras....................................................................................................

4.4.1 Diâmetro médio radicular............................................................................. 52

4.4.2 Comprimento e densidade radicular ao longo do tempo................................. 53

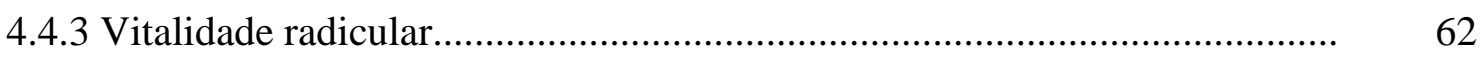

4.5 Produtividade e qualidade tecnológica da cana-de-açúcar.................................. 63

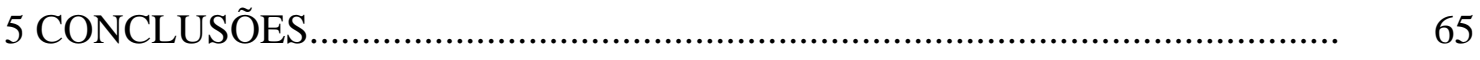

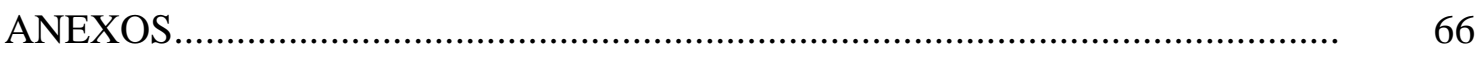

REFERÊNCIAS BIBLIOGRÁFICAS................................................................. 


\section{LISTA DE FIGURAS}

Página

1 Precipitação pluvial (mm) ocorrida no período de 2002 à 2004........................... 23

2 Esquema das trincheiras e da posição utilizada para avaliação do sistema radicular.

3 Escarificação para exposição das raízes de cana no perfil do solo.

4 Número e dimensões das quadrículas em perfil do LVA.

5 Número e dimensões das quadrículas em perfil do NV.

6 Concentração de íons $\mathrm{H}^{+}$e acidez potencial $(\mathrm{H}+\mathrm{Al})$ em duas profundidades dos solos NV e LVA com os cultivares de cana-de-açúcar RB83 5089 e RB83 5486.

7 Teor foliar de macronutrientes e micronutrientes em duas safras para dois cultivares de cana-de-açúcar plantados no solos LVA e NV.

8 Extração de macronutrientes por colmos para os cultivares RB83 5486 e RB83 5089 nos solos LVA e NV

9 Curva de retenção de água para três profundidades dos solos NV e LVA...........

10 Comprimento radicular nos lados esquerdo e direito das linhas de cana-deaçúcar em quatro profundidades no LVA.

11 Comprimento radicular nos lados esquerdo e direito das linhas de cana-deaçúcar em três profundidades no NV.

12 Comprimento radicular de soqueiras de cana-de-açúcar no perfil do LVA...... 50

13 Comprimento radicular de soqueiras de cana-de-açúcar no perfil do NV......... 50

14 Diâmetro médio radicular de dois cultivares de cana-de-açúcar (RB83 5486 e RB83 5089) no LVA.................................................................................... 
15 Diâmetro médio radicular de dois cultivares de cana-de-açúcar (RB83 5486 e

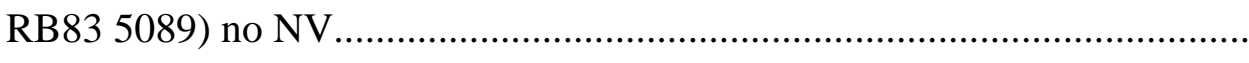

16 Comprimento radicular dos cultivares RB83 5486 e RB83 5089 plantados no LVA em quatro épocas a partir da brotação das soqueiras............................... 54

17 Comprimento radicular dos cultivares RB83 5486 e RB83 5089 plantados no NV em quatro épocas a partir da brotação das soqueiras................................... 55

18 Precipitação no período a partir da brotação da quinta soca............................... 56

19 Densidade radicular ao longo do tempo para os cultivares RB83 5089 e RB83 5486 nos solos NV e LVA............................................................. 61

20 Vitalidade radicular de dois cultivares de cana-de-açúcar em dois solos em função da produção de Trifenilformazan (TF).................................................. 63 


\section{LISTA DE TABELAS}

Página

1 Atributos químicos e teor de macronutrientes em duas profundidades dos solos.

2 Teor de micronutrientes em duas profundidades dos solos........................... 22

3 Resultados da análise granulométrica de diferentes horizontes dos solos....... 22

4 Conteúdo de macronutrientes nos colmos dos cultivares de cana-de-açúcar RB83 5486 e RB83 5089 no LVA e NV (safra 2003/2004)........................... 39

5 Quantidade de macronutrientes em gramas (g) para produção de $1 \mathrm{~kg}$ de ATR nos cultivares RB83 5486 e RB83 5089 nos solos LVA e NV (safra 2003/2004)

6 Média de atributos físicos entre profundidades para os solos LVA e NV.

7 Comprimento de raízes $(\mathrm{cm})$ em três classes de diâmetro de dois cultivares de cana-de-açúcar (RB83 5486 e RB83 5089) no perfil do LVA aos 10, 40, 70 e 160 dias após início da brotação das soqueiras (DBS)

8 Comprimento de raízes $(\mathrm{cm})$ em três classes de diâmetro de dois cultivares de cana-de-açúcar (RB83 5486 e RB83 5089) no perfil do NV aos 10, 40, 70 e 160 dias após início da brotação das soqueiras (DBS)

9 Produção de colmos e de açúcar em três safras para os cultivares RB83 5089 e RB83 5486 plantados em dois solos........................................................ 64

10 Tratamentos dos experimentos instalados nos solos NV e LVA.................. 67

11 Atributos químicos de rotina na profundidade de $0-20 \mathrm{~cm}$ nos solos LVA e NV. 
12 Atributos químicos de rotina na profundidade de 20-40 cm nos solos LVA

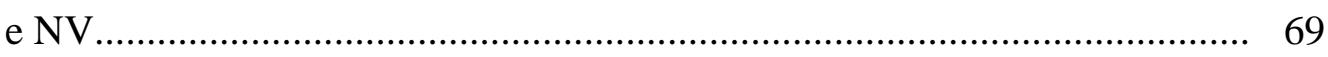

13 Teor de micronutrientes na profundidade de $0-20 \mathrm{~cm}$ dos solos LVA e NV.. 70

14 Teor de micronutrientes na profundidade de 20-40 cm dos solos LVA e NV 71 


\title{
DISTRIBUIÇÃO E CRESCIMENTO RADICULAR EM SOQUEIRAS DE CANA- DE-AÇÚCAR: DOIS CULTIVARES EM SOLOS COM CARACTERÍSTICAS DISTINTAS
}

\author{
Autora: MIRIAN CRISTINA GOMES COSTA \\ Orientador: Prof. Dr. GODOFREDO CESAR VITTI
}

\section{RESUMO}

O presente trabalho de pesquisa foi elaborado com o objetivo de comprovar a hipótese de que o cultivar de cana-de-açúcar RB83 5486, comparado ao RB83 5089, apresenta melhor desenvolvimento radicular mediante cultivo em solo com menor teor de argila. O estudo foi realizado a partir de dois experimentos de campo desenvolvidos no município de Porto Feliz, SP. Os solos foram classificados como Nitossolo Vermelho Eutroférrico latossólico (NV) e Latossolo Vermelho-Amarelo Distrófico psamítico (LVA). Os tratamentos das áreas experimentais foram doze cultivares de cana-de-açúcar em delineamento de blocos completos casualizados. No período entre a terceira soca e a quinta soca (2002 a 2004), dois cultivares de cana-de-açúcar (RB83 5486 e RB83 5089) foram avaliados a partir de estudos de atributos químicos e físicos do solo, do estado nutricional da cultura, da distribuição de raízes no perfil do solo, além da arquitetura e vitalidade radicular a partir da brotação das soqueiras. A distribuição de raízes no perfil do solo foi avaliada utilizando-se o método da trincheira ou parede do perfil. Nesse método, imagens de raízes obtidas na parede de trincheiras abertas no campo foram analisadas por meio do software SIARCS, fornecendo valores de 
comprimento radicular em diferentes distâncias a partir das linhas de cana e em diferentes profundidades. Arquitetura e vitalidade de raízes foram determinadas a partir de raízes lavadas, coletadas no campo por meio de sonda amostradora em diferentes épocas. Para avaliar a arquitetura radicular foram feitas imagens das raízes que, posteriormente, foram analisadas por meio do software WinRhizo. A vitalidade radicular foi determinada por meio de teste enzimático. Os resultados indicaram diferença na concentração de hidrogênio dos solos relacionada com a atividade dos cultivares na absorção de nutrientes. O teor foliar de potássio e enxofre foi maior para o cultivar RB83 5486. Porém, foi observado maior conteúdo e exportação de nutrientes para o cultivar RB83 5089 em virtude da elevada produção de colmos. No LVA a maior quantidade de raízes concentrou-se até os $18 \mathrm{~cm}$ de distância a partir das linhas de cana e até os $54 \mathrm{~cm}$ de profundidade. No NV a maior quantidade de raízes concentrou-se até $23 \mathrm{~cm}$ de distância a partir das linhas de cana e até os $46 \mathrm{~cm}$ de profundidade. O crescimento de raízes a partir da brotação das soqueiras foi influenciado por características de precocidade dos cultivares. A produção de colmos foi maior para o cultivar RB83 5089. Contudo, a produção de açúcar foi maior para RB83 5486 que, no LVA, utilizou menor quantidade de nutrientes por kg de açúcar produzido. 


\title{
ROOT GROWTH AND DISTRIBUTION IN SUGARCANE RATOON: TWO GENOTYPES IN SOILS WITH DISTINCTIVE CHARACTERISTICS
}

\author{
Author: MIRIAN CRISTINA GOMES COSTA \\ Advisor: Prof. Dr. GODOFREDO CESAR VITTI
}

\section{SUMMARY}

To test the hypothesis that, in soils with low clay content, sugarcane genotype RB83 5486 has better root system development than genotype RB83 5089, two field experiments were conducted in Porto Feliz, SP. Soils were classified as Typic Kandiudalf and Typic Hapludox. Twelve sugarcane genotypes were cropped in the experimental sites, with a experimental design in randomized blocks. Between the third and fifth ratoon (2002 to 2004), the development of two sugarcane genotypes (RB83 5486 e RB83 5089) was evaluated by determining the chemical and physical soil attributes, crop nutritional conditions, root distribution in the soil profile, and root architecture and vitality in the ratoon sprout. Root distribution in the soil profile was evaluated by the trench method. Root images were taken from trench walls and analyzed using the SIARCS software. This allowed obtaining the root length values at different distances from sugarcane rows and at different soil depths. Root architecture and vitality was analyzed from washed roots sampled by probe at different times. Architecture was evaluated by means of root images that were later analyzed using the WinRhizo software. The vitality of roots was determined by enzymatic tests. Results show differences in hydrogen ion concentrations in both soils. These differences can be related to differences in the uptake of nutrients between the studied genotypes. 
Potassium and sulphur contents in sugarcane leaves were higher in genotype RB83 5486. However, it was found higher nutrient contents and exportation by stalks in the genotype RB83 5089 due the higher stalk yield. In the Typic Hapludox, most part of roots were concentrated between 0 and $18 \mathrm{~cm}$ from sugarcane rows and in the upper $54 \mathrm{~cm}$. In the Typic Kandiudalf, most part of roots were concentrated between 0 and $23 \mathrm{~cm}$ from sugarcane rows and in the upper $46 \mathrm{~cm}$. Root growth from ratoon sprout was influenced by precocity characteristics of genotypes. Stalk yield was higher in genotype RB83 5089, however, sugar yield was higher in genotype RB83 5486. The genotype RB83 5486 demanded less amount of nutrients by $\mathrm{Kg}$ of produced sugar in the Typic Hapludox. 


\section{INTRODUÇÃO}

A cana-de-açúcar (Saccharum officinarum L.) é uma gramínea tropical que, comparada a outras plantas, apresenta alta eficiência na conversão de energia solar em açúcar. O cultivo da cana-de-açúcar é de grande importância em muitos países, sendo que açúcar refinado e etanol são os principais produtos resultantes dos processos de industrialização.

O Brasil é o maior produtor mundial de cana-de-açúcar e o setor sucroalcooleiro destaca-se na economia nacional, contribuindo de forma expressiva para a geração de divisas. Para garantir a rentabilidade do setor, é fundamental obter elevada produtividade da cultura. Dentre os fatores agronômicos que podem ser manejados na busca de elevada produtividade, destaca-se o melhoramento genético. A partir do melhoramento, são desenvolvidos cultivares melhor adaptados às condições adversas de solo e clima e à incidência de pragas e doenças.

Estudos prévios comparando cultivares de cana-de-açúcar em diferentes solos indicaram que o cultivar RB83 5089 apresentou alto desempenho tanto em solo com elevado potencial (Nitossolo Vermelho Eutroférrico latossólico - maior teor de argila) quanto em solo com baixo potencial produtivo (Latossolo Vermelho-Amarelo Distrófico psamítico - menor teor de argila). Porém, o cultivar RB83 5486 apresentou desempenho inferior ao RB83 5089 no solo com bom potencial produtivo (maior teor de argila) e teve melhor desenvolvimento no solo com baixo potencial produtivo (menor teor de argila).

Com base nessas observações foi elaborado o presente trabalho de pesquisa que teve como objetivo comprovar a hipótese de que o cultivar RB83 5486, comparado ao RB83 5089, apresenta melhor desenvolvimento radicular (representado pela distribuição 
de raízes no perfil do solo e pela dinâmica de crescimento de raízes a partir da brotação de soquerias) mediante cultivo em solo com menor teor de argila. 


\section{REVISÃO DE LITERATURA}

\subsection{A cultura da cana-de-açúcar}

\subsubsection{Produção brasileira}

O Brasil é o principal produtor mundial de cana-de-açúcar. Na safra 2003/2004 a produção nacional foi de 380 milhões de toneladas com as quais foram produzidos 24 milhões de toneladas de açúcar e 14 bilhões de litros de álcool (Jornalcana, 2005). Além de ser o principal produtor mundial em toneladas de cana-de-açúcar, o país também apresenta a maior área plantada com a cultura: cerca de cinco milhões de hectares (FNP, 2005).

A região Sudeste merece destaque no cultivo da cana-de-açúcar, principalmente o Estado de São Paulo que detém cerca de 60\% de toda produção brasileira. A cultura também apresenta produção relevante em outras regiões, como a Nordeste, Sul e CentroOeste.

A exportação de açúcar é uma das principais formas de geração de divisas a partir do cultivo da cana-de-açúcar. Além do açúcar, também é possível produzir álcool que pode ser utilizado como biocombustível. Estima-se que, em 2005, o Brasil obtenha US\$ 3,5 bilhões em divisas com a exportação de 14,3 milhões de toneladas de açúcar e 2,5 bilhões de litros de álcool (Jornalcana, 2005).

A relevância da cana-de-açúcar no agronegócio brasileiro é indiscutível. Apesar de toda tecnologia já empregada nas diferentes etapas de produção, a pesquisa científica ainda tem muito a contribuir para a maximização do processo produtivo, desde a lavoura até a indústria. 


\subsubsection{Cultivares de cana-de-açúcar: RB83 5089 e RB83 5486}

Diversos cultivares foram desenvolvidos na busca de melhores índices de produtividade e qualidade da cana-de-açúcar. A escolha dos cultivares é feita de acordo com as características da região em que a lavoura será estabelecida e com as necessidades da unidade produtora. Se não forem adotados os critérios adequados na escolha do cultivar, a produção pode não ser satisfatória e o impacto na rentabilidade do canavial pode durar até seis anos.

O programa de melhoramento genético da cana-de-açúcar (PMGCA - UFSCar) é responsável pelo desenvolvimento dos cultivares RBs que atualmente ocupam mais de 50\% da área plantada com essa cultura em toda a região meridional brasileira. No censo varietal da safra 2002/2003, o cultivar RB83 5089 situou-se entre os 15 mais plantados. Já o cultivar RB83 5486 esteve entre os três mais plantados na região Centro-Sul, ocupando cerca de 15\% da área cultivada que corresponde a 300.000 hectares (PMGCA, 2005a).

Conforme descrito pelo Programa de Melhoramento Genético da Cana-de-açúcar - PMGCA (2005b), o cultivar RB83 5089 caracteriza-se por apresentar elevada produtividade para cana-planta e cana-soca, baixa exigência em fertilidade do solo, boa brotação de soqueiras, médio perfilhamento e fechamento das entrelinhas, baixa susceptibilidade ao tombamento, baixo florescimento e chochamento, médio teor de sacarose e fibra, precocidade baixa e alta sensibilidade a herbicidas.

O cultivar RB83 5486 é caracterizado por apresentar elevada produtividade para cana-planta e cana-soca, média exigência em fertilidade do solo, boa brotação de soqueiras, médio perfilhamento, bom fechamento das entrelinhas, alta susceptibilidade ao tombamento, médio florescimento, pouco chochamento, teor de sacarose muito elevado, médio teor de fibra, precocidade alta e baixa sensibilidade a herbicidas.

Quanto a ascendência, o cultivar RB83 5089 foi originado a partir de cruzamento biparental entre RB72 454 e NA 56-79, enquanto que o cultivar RB83 5486 foi obtido a partir de policruzamento entre L60-14 e genitor masculino desconhecido.

Recomenda-se que o cultivar RB83 5089 seja plantado tardiamente como cana de ano e meio. O cultivar é destacado por apresentar elevada produtividade agrícola, ampla 
adaptabilidade e alta estabilidade. Para o RB83 5486 não é recomendado o plantio tardio em cana de ano e meio ou em solos mal preparados e secos. O cultivar RB83 5486 destaca-se também pela ampla adaptabilidade, além da altíssima riqueza em sacarose e boa brotação da soca.

Devido a importância científica e econômica, o melhoramento genético deve considerar todas as características da planta que possam tornar um genótipo mais produtivo. A possibilidade de existirem diferenças genotípicas relacionadas ao sistema radicular da planta deve ser melhor explorada na busca de cultivares que apresentem maior eficiência na absorção de água e nutrientes do solo.

\subsubsection{Interação entre cultivares, clima e solo}

Os cultivares de cana-de-açúcar apresentam diferentes exigências quanto aos atributos químicos dos solos em que são plantados. Porém, atributos físicos como densidade, porosidade e resistência à penetração também podem ser decisivos para o bom desenvolvimento.

Dias (1997) estudou a interação de seis cultivares de cana-de-açúcar em diferentes ambientes (solo x clima) e constatou que, em solo eutrófico, com variação textural no perfil e com regime hídrico não limitante ao desenvolvimento das plantas, todos cultivares estudados expressaram plenamente o potencial genético. Entretanto, em solo álico, sem relação textural e com elevada drenagem que conduziu a regime hídrico limitante, os cultivares estiveram muito aquém de seu potencial genético de produtividade.

O plantio dos cultivares RB85 5113, RB85 5536, RB72 454, RB85 5453, RB83 5019, RB83 5486, RB84 5257, SP73-1011 e SP80-1842 nos solos Planossolo e Podzólico Vermelho-Amarelo foi avaliado por Maule et al. (2001). Os autores constataram que os cultivares RB85 5113, RB85 5453, SP79-1011, RB72 454 e SP801842 não apresentaram desenvolvimento diferenciado nos dois solos, provavelmente por apresentarem maior adaptabilidade. Entretanto, os cultivares RB85 5536, RB83 5019, RB83 5486 e RB84 5257 expressaram desenvolvimento variado em função da interação com o ambiente, apresentando diferentes respostas de produtividade agrícola. 
Corrêa et al. (1999) mostraram que o grau de compactação do solo reduziu o rendimento de matéria seca da parte aérea e das raízes de cana-de-açúcar, independente do solo e do cultivar. Os mesmos autores verificaram que o cultivar SP70-1143 apresentou maior potencial de desenvolvimento das raízes em solo compactado quando comparado com o RB72 454.

O estado nutricional de cultivares de cana-de-açúcar pode ser influenciado pelo plantio em diferentes solos. Corrêa et al. (2001) verificaram que a concentração de Ca e Mg teve influência do solo e do cultivar, sendo que a concentração de Ca foi reduzida com a compactação em um LR, independente do cultivar estudado. Mediante cultivo em LVA, houve máxima concentração de Ca para o cultivar RB72 454.

Gomes (2003) demonstrou que a média de produtividade de três cortes do cultivar RB83 5089 plantado em solo com menor teor de argila foi aproximadamente 20 toneladas maior que a encontrada para o RB83 5486. Entretanto, quando plantado em solo de textura arenosa na mesma época, o cultivar RB83 5089 apresentou média de três cortes 10 toneladas menor que o RB83 5486.

\subsection{Sistema radicular}

Dentre as funções das raízes, destacam-se a absorção de água e nutrientes, além da sustentação das plantas. As partes constituintes das raízes são: colo, zona pilífera, zona lisa ou de crescimento, coifa e zona terminal. Internamente, as raízes apresentam epiderme, exoderme, esclerênquima, córtex, córtex interno, endoderme, periciclo, parênquima intersticial, parênquima, xilema e floema (Waisel et al., 1996).

Na organização dos tecidos destaca-se o meristema apical no qual ocorre divisão celular. Das células formadas no meristema apical desenvolvem-se o cilindro vascular (xilema, floema e periciclo), o córtex e a epiderme a partir da qual desenvolvem-se os pêlos radiculares.

O desenvolvimento do sistema radicular a partir do meristema apical difere entre monocodiledôneas e dicotiledôneas. Em monocotiledôneas as raízes atingem o diâmetro máximo quando as células estão completamente expandidas e o cilindro apresenta 
tamanho praticamente uniforme em raízes adultas, exceto quando fatores ambientais provocam alguma modificação nas raízes. Já em dicotiledôneas, o diâmetro de raízes adultas pode ser aumentado como resultado de divisão celular tangencial ao eixo da raiz, principalmente no câmbio vascular. Tal característica em dicotiledôneas perenes resulta na força mecânica das raízes de sustentação (Russell, 1977).

Com a remoção da região apical das raízes não há interrupção no crescimento. Outras funções são atribuídas ao ápice, como a produção de mucilagem e a regulação do geotropismo (Juniper et al., 1966). Estudos indicam que no ápice radicular há produção de ácido abscísico (Wilkins \& Wain, 1975).

A mucilagem é um material não celular gelationoso que está presente em maior quantidade na extremidade das raízes. O contato entre raízes em crescimento e a matriz sólida do solo é estabelecido mais pela mucilagem do que pela própria parede das células radiculares. Leiser (1968) sugere que a substância protege a extremidade da raiz contra dessecação. Dart \& Mercer (1964) consideram que a substância favorece o ambiente garantindo rápida multiplicação de microrganismos e o acúmulo de exsudados. Também se sugere que a mucilagem exerça algum papel na absorção de nutrientes da solução do solo, contribuindo para aumentar o contato entre raízes e partículas de solo (Jenny \& Grossenbacher, 1963).

Outra importante característica do sistema radicular é a formação de pêlos que sofre grande influência do ambiente. A área superficial dos pêlos radiculares pode exceder a área formada pelas raízes primárias e secundárias. Esses pêlos radiculares atuam na absorção de água e nutrientes e, mediante compactação do solo, seu desenvolvimento é comprometido. Pêlos radiculares também contribuem para sustentar raízes novas quando essas penetram o solo, principalmente quando seu crescimento encontra algum tipo de impedimento mecânico (Stozy \& Barley, 1968).

Em condições de campo, as raízes das plantas apresentam grande variabilidade de desenvolvimento e isto se deve tanto às características ambientais quanto às morfológicas. Apesar da grande variabilidade, o desenvolvimento compensatório não é aleatório. Tal desenvolvimento pode ocorrer como conseqüência da variação na 
concentração de nutrientes na solução do solo, da temperatura ou de impedimento mecânico (Russell, 1977).

Russell (1977) menciona que há ampla evidência de diferenças intervarietais no crescimento de raízes. Apesar das evidências do controle gênico em características de enraizamento, esse não tem sido objetivo dos programas de melhoramento genético. Anghinoni et al. (1989) verificaram que a magnitude do sistema radicular aumentou com o grau de tolerância de genótipos de trigo com relação às condições adversas de fertilidade e acidez do solo. Os mesmos autores também encontraram diferenças no sistema radicular de diferentes genótipos de milho e arroz.

\subsubsection{Contribuição de diferentes partes do sistema radicular na nutrição mineral das plantas}

Em condições naturais, diferentes partes do sistema radicular são submetidas a ambientes contrastantes, dependendo de sua distância em relação à superfície. Assim, torna-se importante conhecer a contribuição de cada parte na nutrição de toda planta.

A princípio acreditava-se que as regiões mais velhas das raízes não eram ativas na absorção de água e nutrientes devido ao engrossamento da endoderme. Entretanto, estudos mostraram absorção de fosfato e potássio em todo sistema radicular, incluindo raízes velhas. A absorção de cálcio ocorre preferencialmente em raízes novas (HarrisonMurray \& Clarkson, 1973).

É preciso ponderar qual parâmetro é mais relevante na absorção de nutrientes: comprimento radicular, área superficial, volume ou o peso de raízes. Russell (1977) afirma que a área superficial é o parâmetro mais relevante. Para espécies de cereais, quando a concentração externa de nutrientes é similar em toda superfície de raízes, a eficiência de absorção apresenta maior relação com o volume de raízes do que com o comprimento ou área superficial (Harrison-Murray \& Clarkson, 1973).

Da mesma forma que o sistema radicular influencia a absorção de nutrientes, ele também é influenciado por ela. As modificações que podem ocorrer são de grande importância prática, pois com a adubação intensifica-se o gradiente de nutrientes na 
solução do solo. Existem relatos de redução na massa de raízes, além de mudanças no volume e distribuição lateral mediante deficiência de potássio e fósforo (Hackett, 1968).

\subsubsection{Desenvolvimento de raízes e condições do solo}

Condições desfavoráveis do solo, restritivas ao desenvolvimento de raízes, constituem a razão mais comum pela qual as culturas não conseguem expressar todo seu potencial genético de produtividade. As condições desfavoráveis podem ser de três tipos: estresse biológico, estresse químico e estresse físico.

O estresse biológico pode ser causado pela flora e fauna do solo (Russell, 1977). O estresse químico deve-se à deficiência de nutrientes, ao desbalanceamento entre os nutrientes existentes, ou à presença de elementos tóxicos. Diversos trabalhos de pesquisa mostram a influência de atributos químicos do solo no desenvolvimento de raízes. Zhang \& Rengel (1999) estudaram os efeitos do pH e das concentrações de amônio e fósforo das faixas de adubação no desenvolvimento das raízes de trigo. Dunbabin et al. (2001) estudaram o crescimento de raízes de diferentes espécies de tremoço mediante suprimento heterogêneo de nitrato. Ma et al. (2002) avaliaram o crescimento de raízes e a concentração citoplasmática de cálcio na extremidade de raízes de centeio mediante excesso de alumínio no solo.

O estresse físico pode ser caracterizado pelo inadequado suprimento de água, pelo impedimento mecânico à penetração de raízes, por condições de anaerobiose ou pela temperatura inadequada do solo. Densidade, porosidade e resistência à penetração atuam como atributos que auxiliam na avaliação do estresse físico do solo que interfere no desenvolvimento do sistema radicular das plantas.

Densidade do solo é definida como massa de solo seco por unidade de volume que inclui tanto a fase sólida quanto a fase gasosa. Veihmeyer \& Hendrickson (1948) verificaram que a máxima densidade do solo que possibilita penetração de raízes é de $1,46 \mathrm{~g} \mathrm{~cm}^{-3}$ em solo argiloso e $1,75 \mathrm{~g} \mathrm{~cm}^{-3}$ em solo arenoso.

O crescimento de raízes é inibido por camadas de solo extremamente adensadas devido a inúmeros fatores como a resistência do solo à penetração, aeração deficiente, baixo movimento de nutrientes e água, além da formação de locais com acúmulo de 
gases tóxicos e exsudados de raízes. Em condições de campo, muitas vezes o sistema radicular pode ser afetado por estresse mecânico sem, contudo, afetar a produção das culturas (Russell, 1977).

Diretamente ligada à definição de densidade do solo está a porosidade que é a medida do espaço poroso. A porosidade total é uma medida dimensional $\left(\mathrm{cm}^{3} \mathrm{~cm}^{-3}\right)$, geralmente expressa em porcentagem e que é afetada pela compactação. Quanto maior a densidade do solo, menor a porosidade total (Reichardt, 1996).

De acordo com o tamanho, os poros são classificados como macroporos (maiores que $0,08 \mathrm{~mm}$ ) e microporos (menores que $0,08 \mathrm{~mm}$ ). Macroporos permitem rápido movimento de ar e água, são amplos o suficiente para acomodar raízes de plantas e grande diversidade de pequenos animais. Microporos normalmente são preenchidos com água e, quando não possuem água, são extremamente pequenos para viabilizar o movimento de ar. O movimento de água em microporos é lento e grande quantidade da água retida nestes poros não está disponível às plantas (Brady \& Weil, 1999).

Textura e estrutura do solo influem no balanço entre macroporos e microporos. A redução no teor de matéria orgânica e o aumento no teor de argila que ocorre em profundidade em muitos perfis de solo, estão associadas com aumentos na proporção de microporos em detrimento aos macroporos (Brady \& Weil, 1999).

O tamanho, a forma e a conexão dos poros atuam de maneira importante na drenagem, aeração e na retenção de água. Para uma amostra de solo homogêneo, o potencial mátrico apresenta valor específico para cada teor de água. O gráfico do potencial mátrico em função da umidade é uma característica da amostra e recebe a denominação de "curva característica da umidade do solo", ou simplesmente, "curva de retenção” (Reichardt, 1996).

Com a curva de retenção elaborada a partir da aplicação de diferentes tensões em amostras indeformadas de solo, busca-se a determinação da água considerada disponível às plantas. Veihmeyer \& Hendrickson (1949) afirmam que água disponível é aquela que está no intervalo entre um limite superior (Capacidade de campo - CC) e limite inferior (Ponto de murcha permanente - PMP). 
A umidade do solo na qual a drenagem interna cessa é denominada CC e é considerada como critério para definir o limite superior de água que o solo pode reter. Para solos de regiões tropicais assume-se que na CC a água está retida a uma tensão de $10 \mathrm{kPa}$ (Haise et al., 1955). O PMP foi definido por Veihmeyer \& Hendrickson (1949) como a umidade do solo na qual uma planta não túrgida não restabelece a turgidez, mesmo quando colocada em atmosfera saturada por 12 horas. Assume-se que esta umidade do solo corresponde a um potencial de $1500 \mathrm{kPa}$.

Além da densidade, porosidade e das características de retenção de água no solo, a resistência à penetração é outro importante indicativo das condições para o desenvolvimento de raízes. Penetrabilidade é definida como medida da facilidade com que um objeto pode penetrar no solo. A resistência à penetração é influenciada por características do penetrômetro utilizado em sua determinação e por características do solo como umidade, densidade, compressibilidade, força e estrutura (Bradford, 1986).

Para grande parte das culturas, o crescimento radicular é reduzido drasticamente quando a resistência à penetração está na faixa de 2 MPa (Bradford, 1986). Boone et al. (1986) encontraram que o limite mecânico superior para o desenvolvimento de raízes de milho foi de 3 MPa para solos homogêneos sem grandes variações em profundidade dos teores de matéria orgânica ou de textura.

Alterações morfológicas nas raízes podem ocorrer em virtude das variações na resistência à penetração. Rosolem et al. (2002) não encontraram aumento no diâmetro de raízes das espécies estudadas quando a resistência à penetração foi de 1,34 MPa. Porém, os mesmos autores mencionaram que o efeito da compactação do solo no diâmetro das raízes depende da resistência à penetração.

\subsubsection{Raízes de cana-de-açúcar}

As raízes de cana-de-açúcar são classificadas como raízes do tolete (ou de fixação) e raízes do perfilho primário. As raízes do tolete originam-se nos primórdios radiculares do tolete de plantio, são delgadas e muito ramificadas. As raízes do perfilho primário originam-se a partir dos primórdios radiculares do perfilho, sendo mais espessas, com coloração clara e menos ramificadas (Dillewijn, 1952). 
No período entre plantio e formação de raízes do perfilho, as raízes do tolete promovem a absorção de água e nutrientes. A funcionalidade das raízes do tolete diminui na medida em que as raízes do perfilho são formadas. As raízes do perfilho também apresentam funcionalidade por tempo limitado. Entretanto, como cada novo perfilho forma raízes, o sistema radicular está em contínua renovação (Dillewijn, 1952).

Quanto a distribuição no perfil de solo, Evans (1935) distingue diferentes tipos de raízes de cana: a) raízes superficiais de absorção que se originam nos primórdios radiculares; b) raízes de sustentação que estão intermediárias entre as superficiais e as mais profundas e que, quando jovens, possuem crescimento ativo e grande quantidade de pêlos radiculares e c) raízes-cordão que são as mais profundas e cuja principal função é o suprimento de água.

Morfologicamente, Dillewijn (1952) menciona que raízes novas são de coloração clara e túrgidas. Conforme as raízes tornam-se velhas, o córtex fica flácido e escuro. O córtex de partes mais velhas apresenta tecido morto e escurecido, entretanto o cilindro central pode ainda estar vivo.

Avilan et al. (1977) mencionaram que os fatores que mais afetam o sistema radicular da cana-de-açúcar são o nível do lençol freático, o impedimento mecânico e as características químicas do solo. Avilan et al. (1978) verificaram que, na profundidade entre 25 e 50 cm, a baixa macroporosidade restringiu a penetração radicular.

Densidade do solo maior que $1,02 \mathrm{~g} \mathrm{~cm}^{-3}$ causou deformação ou restrições na distribuição de raízes de cana-de-açúcar; densidade de $1,25 \mathrm{~g} \mathrm{~cm}^{-3}$ causou danos nas radicelas; densidade de 1,36 $\mathrm{g} \mathrm{cm}^{-3}$ reduziu a quantidade de raízes e causou distorção nas radicelas; densidade maior ou igual a $1,46 \mathrm{~g} \mathrm{~cm}^{-3}$ comprometeu a penetração das raízes no solo (Humbert, 1974). Queiroz-Voltan et al. (1998) verificaram que densidade do solo de 1,23 $\mathrm{g} \mathrm{cm}^{-3}$ não provocou alterações histológicas significativas em raízes de cana-de-açúcar.

Avilan et al. (1978) verificaram que a maior concentração radicular ao redor das soqueiras está na distância de 0 a 35 cm, enquanto que a menor concentração radicular está na distância de 35 a 70 cm da touceira. Os mesmos autores encontraram que a maior concentração de raízes está na profundidade de 30 a 50 cm. Fernandes (1985) menciona 
que 60 a 70\% das raízes de cana-de-açúcar estão nos primeiros $40 \mathrm{~cm}$ de profundidade na fase inicial de desenvolvimento da cultura. Já a maior concentração de raízes na horizontal está a 30-40 cm das linhas de cana. Estudando o crescimento de raízes de cana colhida com queima e sem queima, Alvarez et al. (2000) verificaram que $75 \%$ das raízes de cana colhida sem queima situaram-se nos primeiros $40 \mathrm{~cm}$ de profundidade do solo no primeiro ano de análise e 70\% das raízes concentraram-se nessa profundidade na avaliação de segundo ano. Já para cana colhida queimada, os valores foram de $72 \%$ de raízes nos primeiros $40 \mathrm{~cm}$ no primeiro ano e $68 \%$ no segundo ano.

Fernandes (1985) cita que no primeiro período de crescimento vegetativo, canaplanta e cana-soca dependem do sistema radicular proveniente do tolete de plantio ou das reservas do rizoma. Com o desenvolvimento, novas raízes são emitidas e substituem gradualmente as raízes anteriores que permanecem ativas durante 90 a 120 dias. Casagrande (1991) relata que um novo sistema radicular é formado concomitante à brotação das soqueiras.

Crescimento radicular de até oito centímetros por dia já foi verificado por Humbert (1974). O mesmo autor destacou que o sistema radicular da cultura se adapta às características do meio. Vasconcelos (2003) menciona que o sistema radicular da canade-açúcar é extremamente dependente da cultivar. Vasconcelos (1998) ${ }^{1}$ citado por Vasconcelos (2003), estudando o sistema radicular de cana aos 10 e 16,5 meses após o plantio, verificou desenvolvimento diferenciado na quantidade e distribuição de raízes no perfil do solo para doze genótipos.

\footnotetext{
${ }^{1}$ VASCONCELOS, A.C.M. Comportamento de clones IAC e variedades de cana-de-açúcar (Saccharum spp.) nas condições edafoclimáticas da região do Vale do Paranapanema. Jaboticabal, 1998. 108 p. Dissertação (Mestrado) - Faculdade de Ciências Agrárias e Veterinárias - Universidade Estadual Paulista "Júlio de Mesquita Filho".
} 


\subsection{Métodos para estudo do sistema radicular}

Dentre os métodos utilizados para estudo de raízes, destacam-se: trincheira ou parede do perfil; blocos ou monolito; placa com pregos; sonda e “rhizotron” (Jorge et al., 1996). Os métodos podem ser associados às técnicas isotópicas.

Para avaliar a distribuição de raízes in situ, tem sido utilizado o método da trincheira ou parede do perfil. Tal método consiste em cavar trincheira ao lado da planta e remover fina camada da parede do perfil, expondo as raízes que posteriormente serão contadas e registradas (Böhn, 1979).

O método de blocos ou monolito consiste da retirada de amostras de solo em blocos de dimensões definidas para posterior lavagem, separação e determinação de comprimento ou peso das raízes. No procedimento de lavagem pode ocorrer perdas de radicelas e, para os diferentes métodos de lavagem, as perdas podem variar de 20 a 40\% de matéria seca (Noordwijk \& Floris, 1979).

Como variação do método de blocos ou monolito, tem-se o método da placa com pregos. A placa é pressionada contra a parede da trincheira onde estão as raízes, retirando-se posteriormente bloco único, onde as raízes permanecerão na posição original após lavagem em função da presença de pregos. A maior dificuldade desse método é a penetração da placa em perfis de solos argilosos (Jorge et al., 1996).

No método da sonda, a ferramenta é utilizada para retirada de amostras de solo com raízes em diferentes profundidades e distâncias. As amostras são lavadas para separação das raízes. As principais limitações do método são a lavagem (Jorge et al., 1996) e a retirada de amostras em solos argilosos. Como vantagem, tem-se a possibilidade de retirada de grande número de amostras.

O “rhizotron” é um tipo de recipiente de vidro inserido no solo, no qual a planta se desenvolve e por meio do qual é possível visualizar o desenvolvimento das raízes in 
vivo. Devido à facilidade que as raízes encontram para desenvolvimento próximo à parede de vidro, este é um método mais adequado para estudos fenológicos do que para estudos de distribuição de raízes (Böhn, 1979).

A técnica isotópica $\left({ }^{15} \mathrm{~N}\right)$ tem sido utilizada em estudos de avaliação da biomassa radicular e do nitrogênio mineral do solo proveniente da decomposição de raízes (Russell \& Fillery, 1996; McNeill et al., 1998; Khan et al., 2002; Khan et al., 2003). Russell \& Fillery (1996) destacam que a técnica isotópica, por proporcionar o estudo "in situ”, mantém o padrão natural de decomposição das raízes. Além disso, consegue-se padrão real de distribuição das raízes no perfil do solo. Ao utilizar ${ }^{15} \mathrm{~N}$, a fonte isotópica é aplicada na parte aérea das plantas e, posteriormente, é feita análise para verificar a recuperação na parte aérea e no sistema radicular. Do ponto de vista operacional, o uso de isótopos no estudo de raízes é favorável, pois torna dispensável os processos de separação entre raízes e solo. Como desvantagem do uso de isótopos no estudo de raízes, está o fator custo que, dependendo da situação, pode ser elevado.

Vasconcelos et al. (2003) em estudo no qual compararam métodos para avaliação do sistema radicular de cana-de-açúcar, verificaram que o método do perfil do solo com a contagem do número de raízes ou com a filmagem e quantificação por meio de programa de computador apresentou menores coeficientes de variação. O método de análise do sistema radicular em que se utiliza a sonda, com apenas duas subamostras, superestimou a quantidade de raízes e os métodos de estudo em perfil foram os mais adequados para detectar diferenças entre tratamentos.

A descrição e quantificação do sistema radicular podem ser facilitadas quando se faz uso da análise de imagens. Imagens de raízes no perfil do solo podem ser analisadas por software, medindo-se parâmetros como comprimento, área superficial radicular e classes de diâmetro de raízes. Alguns autores ressaltam que essa análise é facilitada quando se trabalha com imagens de raízes lavadas (Kimura et al., 1999) e dificultada quando se analisa imagem de raízes coletada no perfil do solo. A maioria dos procedimentos usados na estimativa do comprimento radicular baseia-se em modificações do método da interseção proposto por Newman (1966) e aperfeiçoado por Tennant (1975). 
Diversos são os programas computacionais desenvolvidos para estudo das imagens digitalizadas de raízes (Jourdan \& Rey, 1997; Ingram \& Leers, 2001). O programa SIARCS (Sistema Integrado para Análise de Raízes e Cobertura do Solo) permite avaliar qualitativa e quantitativamente a distribuição de raízes, eliminando-se grande parte da subjetividade encontrada nos métodos de perfil, melhorando a precisão na análise (Guimarães et al., 1997).

Estudando o sistema radicular de cana-de-açúcar por meio do software SIARCS, Crestana et al. (1994) verificaram que o método exige cuidados ao se interpretar a imagem obtida na tela. O processamento ajuda na interpretação da imagem, porém o processamento em si não é capaz de indicar se o resultado de sua aplicação está ou não próximo do real. Isso quem deve fazer é o usuário, interagindo diretamente com os resultados produzidos pelo sistema.

O programa denominado WinRHIZO Basic (Regent) tem sido utilizado em estudos nos quais são avaliadas raízes lavadas. Trata-se de um sistema de análise de imagens específico para avaliação de raízes. O programa avalia a morfologia (comprimento, área, volume), topologia, arquitetura e coloração, sendo composto por um programa de computador e por componentes de aquisição de imagens. Himmelbauer et al. (2004) apresentam resultados mostrando que o programa promove medidas corretas de parâmetros morfológicos, mostrando-se adequado para estudos de avaliação de raízes lavadas.

\subsection{Vitalidade radicular}

Estudos de dinâmica de raízes não podem ser realizados sem separação de raízes de acordo com sua vitalidade (Joslin \& Henderson, 1984). Para Comas et al. (2000), a distinção entre raízes vivas e mortas é parte fundamental de muitos estudos. Definições de como raízes mortas diferem das vivas dificultam a comparação de resultados de estudos de dinâmica de raízes. O uso de corantes vitais surge como uma possibilidade para diferenciação entre raízes vivas e mortas. 
Corantes vitais são substâncias que possibilitam a observação de células vivas, principalmente quanto a sua fisiologia, danos causados às células e ocorrência de células mortas. Existem três pré-requisitos para que uma substância seja considerada corante vital: 1) habilidade para entrar em diferentes tipos de célula; 2) passar através do citoplasma sem matar as células e 3) colorir inclusões celulares preexistentes distintivamente (Cannon \& Cannon, 1994).

Dentre as substâncias que podem ser utilizadas como corantes vitais, encontra-se a "fucsina” (ácida ou básica). Em técnicas com plantas, a fucsina ácida é utilizada para colorir córtex, parênquima e parede celulósica. O corante reage rapidamente e é facilmente extraído por álcool concentrado (Conn, 1969). A fucsina básica (também encontrada na literatura como "Pararosanilina") apresenta 0,26\% de solubilidade em água e 5,93\% em álcool. Trata-se de um corante nuclear de grande potencial e, para uso comum, é suficiente utilizar solução em água destilada (Conn, 1969).

Ball-Coelho et al. (1992) em estudo da dinâmica das raízes de soqueiras de canade-açúcar, armazenaram raízes em água destilada com algumas gotas de carbol fucsina e tolueno e mantiveram as raízes congeladas. Os mesmos autores utilizaram a fucsina básica para auxiliar na distinção visual entre raízes vivas e mortas.

O emprego de corantes vitais para distinção visual entre raízes vivas e mortas pode ser inadequado nas situações em que raízes vivas e ativas tornam-se externamente escurecidas devido às características da espécie estudada e/ou ao tipo de substrato no qual a planta se desenvolveu. Nesta situação surge a necessidade de procedimento analítico que viabilize a distinção entre raízes vivas e mortas a partir de outros critérios que não sejam exclusivamente visuais.

O cloreto de trifeniltetrazólio (2,3,5-triphenyl-2H-tetrazolium chloride $\mathrm{C}_{19} \mathrm{H}_{15} \mathrm{ClN}_{4}$ ), também identificado pela sigla TTC, é um sal normalmente utilizado para determinar o poder de germinação de sementes. O teste de tetrazólio baseia-se no princípio de que tecidos vivos contém enzimas desidrogenase ativas que catalisam reações químicas de redução. Na presença da enzima desidrogenase, o sal de tetrazólio incolor é transformado em formazan (TF) que possui coloração avermelhada (Steponkus \& Lanphear, 1967). 
Nos tecidos vegetais o TTC é reduzido principalmente por enzimas desidrogenase, muitas das quais estão associadas com a função mitocondrial. Embora a redução do TTC componha um teste já estabelecido de vitalidade, os fatores responsáveis pela capacidade das raízes reduzirem o trifeniltetrazólio ainda não são completamente entendidos (Comas et al., 2000).

Jacques \& Schwass (1956) foram os primeiros a separar raízes vivas de mortas usando a redução do TTC à TF. Knievel (1973) analisou grande número de amostras de raízes e encontrou correlação entre peso seco de raízes vivas e a absorbância do extrato da solução formazan-etanol. Porém, o autor trabalhou com raízes de plantas herbáceas não suberizadas, deixando dúvidas a respeito da eficiência do método para raízes suberizadas. Joslin \& Henderson (1984) testaram o procedimento de Knievel (1973) e verificaram que este pode ser utilizado de maneira adequada para raízes suberizadas.

Wang et al. (1995), separaram raízes vivas das mortas, com base no teste com TTC. Os autores observaram que 12 a 18\% das raízes que apresentaram porção escurecida foram aptas a reduzir o TTC. Assim, os autores concluíram que 12 a 18\% das raízes foram consideradas erroneamente como mortas quando analisadas apenas por critério visual.

Comas et al. (2000) encontraram alta correlação entre redução do TTC e respiração de raízes de videira em diferentes idades. A atividade metabólica avaliada pela redução do TTC e respiração reduziu com a idade da raiz. Raízes de coloração marrom apresentaram redução do TTC em poucas células do córtex e nenhuma atividade no cilindro, indicando que o órgão não estava funcional. Já as raízes de coloração mais escura não apresentaram atividade em nenhuma região. Os autores concluíram que, entre raízes com diâmetro inferior a 0,6 mm, aquelas de coloração marrom estavam senescentes, enquanto que aquelas raízes muito escurecidas estavam mortas.

A correlação encontrada por Comas et al. (2000) entre pigmentação e atividade metabólica em videira, talvez não ocorra para todas espécies de planta. Segundo os autores, um ponto importante a ser considerado é que o TTC parece descrever uma medida direta da respiração, encontrando correspondência próxima entre nível de pigmentação e declínio na atividade de raízes. 
Ruf \& Brunner (2003) mencionam que a maior desvantagem das análises para diferenciar tecido vivo e morto com TTC é que, tanto raízes mortas quanto raízes que foram previamente fervidas para eliminação da atividade metabólica, produziram trifenilformazan. Em estudo preliminar, os mesmos autores verificaram que materiais da parede celular como celulose e pectina, interagiram com o TTC mediante temperaturas superiores a $60{ }^{\circ} \mathrm{C}$, reduzindo-o a trifenilformazan. Os autores concluíram que a temperatura de $80{ }^{\circ} \mathrm{C}$ convencionalmente utilizada na extração de TF por etanol pode ser responsável por uma formação artificial de TF. No procedimento de extração, o etanol aquecido apresenta as funções de romper as células e de solubilizar o TF. Assim, os autores sugeriram procedimento alternativo com a eliminação da alta temperatura na extração, visando eliminar a formação artificial de TF. 


\section{MATERIAL E MÉTODOS}

\subsection{Localização das áreas experimentais, tipos de solo e precipitação}

O estudo foi realizado a partir de dois experimentos de campo instalados em agosto de 1998, com o plantio antecipado de cana de ano denominado plantio "de inverno". Pequena distância separou as áreas experimentais, situadas no município de

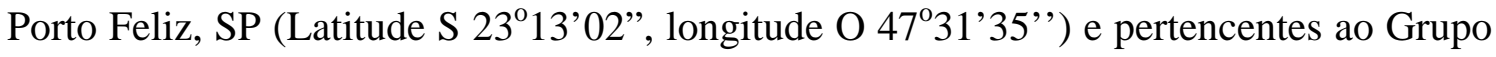
COSAN. A altitude predominante na região é de 554 metros e o clima é Cwa (sistema de Koeppen), caracterizado por verões quentes e invernos secos (São Paulo, 1972).

Os solos das áreas experimentais foram classificados como Latossolo VermelhoAmarelo Distrófico psamítico (LVA) e como Nitossolo Vermelho Eutroférrico latossólico (NV) (Embrapa, 1999). Nas Tabelas 1 e 2 são apresentados resultados de análises químicas de amostras coletadas antes da instalação dos experimentos. Na Tabela 3 são apresentados os resultados da análise textural. 
Tabela 1. Atributos químicos e teor de macronutrientes em duas profundidades dos solos

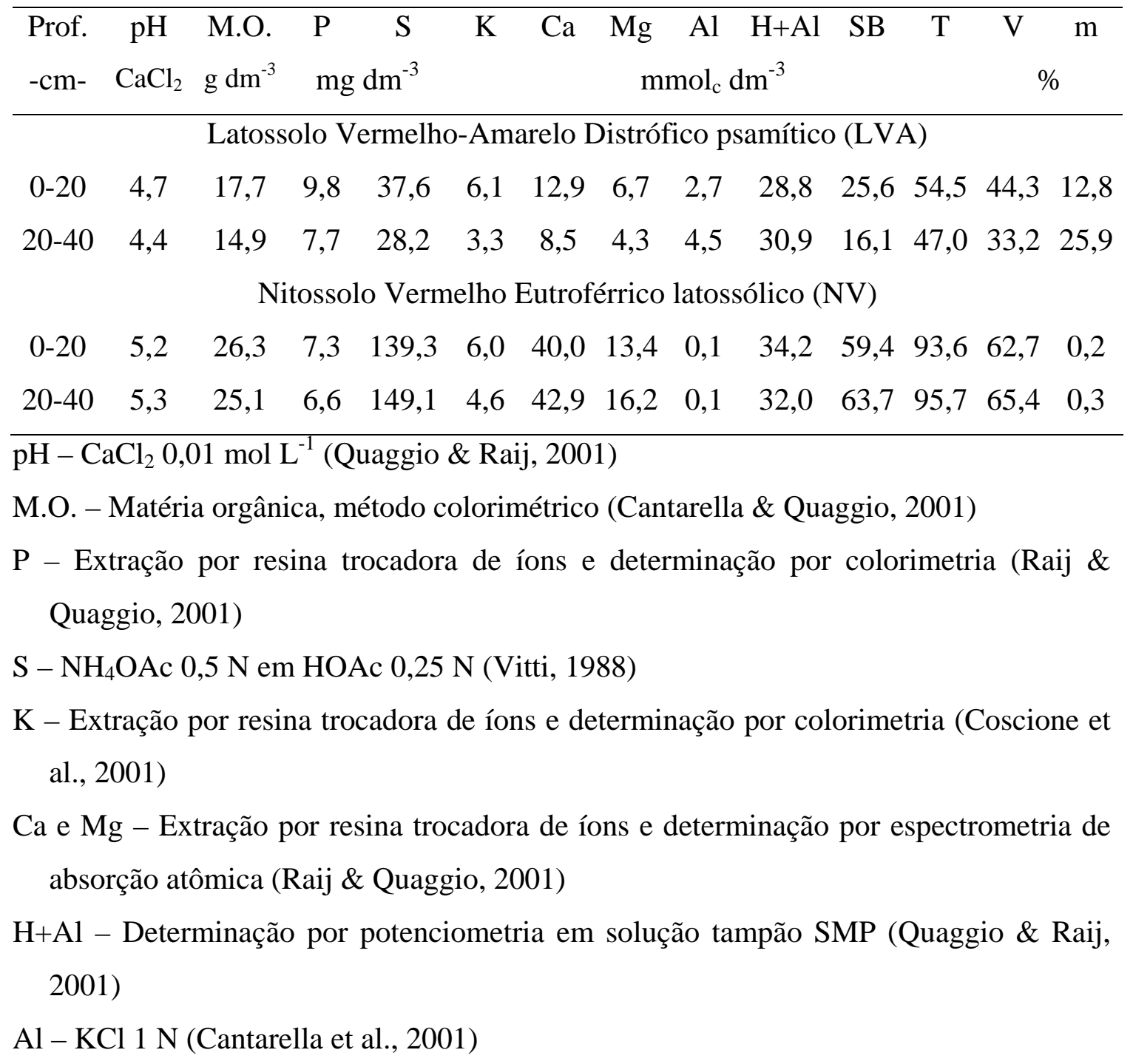


Tabela 2. Teor de micronutrientes em duas profundidades dos solos

\begin{tabular}{|c|c|c|c|c|c|c|}
\hline $\begin{array}{l}\text { Prof. } \\
\mathrm{cm}\end{array}$ & B & $\mathrm{Cu}$ & $\begin{array}{c}\mathrm{Fe} \\
\mathrm{mg} \mathrm{dm}^{-3}\end{array}$ & $\mathrm{Mn}$ & & $\mathrm{Zn}$ \\
\hline \multicolumn{7}{|c|}{ Latossolo Vermelho-Amarelo Distrófico psamítico (LVA) } \\
\hline $0-20$ & 0,5 & 0,3 & 56,8 & 6,8 & & 0,3 \\
\hline $20-40$ & 0,1 & 0,2 & 46,3 & 4,2 & & 0,2 \\
\hline \multicolumn{7}{|c|}{ Nitossolo Vermelho Eutroférrico latossólico (NV) } \\
\hline $0-20$ & 0,3 & 9,8 & 28,1 & 122,0 & & 0,5 \\
\hline $20-40$ & 0,2 & 9,7 & 22,7 & 93,2 & & 0,4 \\
\hline \multicolumn{7}{|c|}{$\mathrm{B}-\mathrm{BaCl}_{2} 2 \mathrm{H}_{2} \mathrm{O}$ 0,125\% microondas (Abreu et al., 2001a) } \\
\hline \multicolumn{7}{|c|}{ Cu, Fe, Mn, Zn - DTPA - TEA pH 7,3 (Abreu et al., 2001b) } \\
\hline \multicolumn{7}{|c|}{$\begin{array}{l}\text { Tabela 3. Resultados da análise granulométrica de diferentes horizontes dos solos c } \\
\text { áreas experimentais }\end{array}$} \\
\hline Horizonte & & Areia & Argila & & Silte & \\
\hline $\mathrm{cm}$ & & & $\%$ & & & \\
\hline \multicolumn{7}{|c|}{ Latossolo Vermelho-Amarelo Distrófico psamítico (LVA) } \\
\hline $0-30$ & & 83 & 12 & & 5 & \\
\hline $31-75$ & & 79 & 12 & & 9 & \\
\hline 76-105 & & 79 & 15 & & 6 & \\
\hline $106+$ & & 81 & 15 & & 4 & \\
\hline \multicolumn{7}{|c|}{ Nitossolo Vermelho Eutroférrico latossólico (NV) } \\
\hline $0-30$ & & 40 & 51 & & 9 & \\
\hline 31-65 & & 28 & 65 & & 7 & \\
\hline $66-75$ & & 30 & 62 & & 8 & \\
\hline $76+$ & & 23 & 62 & & 15 & \\
\hline
\end{tabular}

Método do densímetro (Gee \& Bauder, 1986) 
A precipitação pluvial foi determinada para os anos de 2002, 2003 e 2004, a partir de pluviômetros localizados a 50 metros do experimento instalado no NV e a $5 \mathrm{~km}$ (em linha reta) do local onde foi instalado o experimento no LVA (Figura 1).

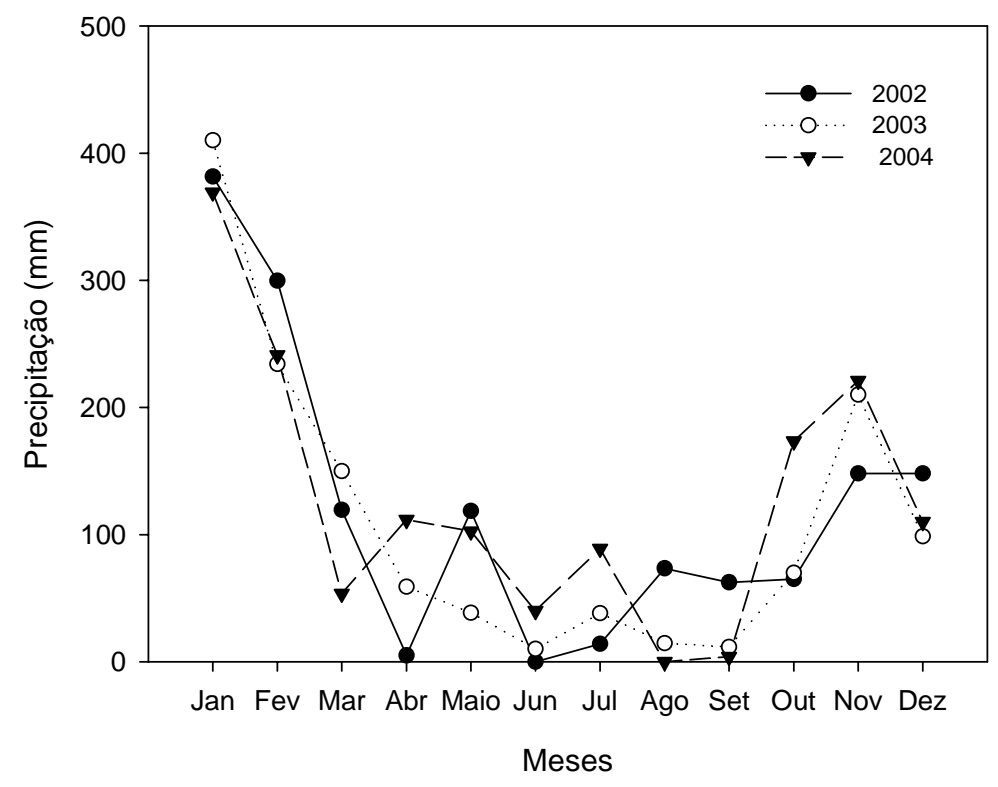

Figura 1 - Precipitação pluvial (mm) ocorrida no período de 2002 à 2004

\subsection{Manejo da cultura}

O espaçamento de plantio foi 1,40 m entre-linhas no solo com elevada fertilidade natural (NV) e 1,10 m entre-linhas no solo com baixa fertilidade natural (LVA). No sulco de plantio foram aplicados $90 \mathrm{~kg} \mathrm{ha}^{-1}$ de $\mathrm{P}_{2} \mathrm{O}_{5}$ na forma de superfosfato triplo.

Até a safra 2001/2002, as áreas experimentais receberam $150 \mathrm{~m}^{3} \mathrm{ha}^{-1} \mathrm{de}$ vinhaça fornecendo, de acordo com as análises químicas do resíduo, 126, 13 e $645 \mathrm{~kg} \mathrm{ha}^{-1}$ de N, $\mathrm{P}_{2} \mathrm{O}_{5}$ e $\mathrm{K}_{2} \mathrm{O}$, respectivamente. A partir da safra 2002/2003, no cultivo das soqueiras, ambas áreas experimentais receberam aplicações de $500 \mathrm{~kg} \mathrm{ha}^{-1}$ da fórmula 18-00-27, fornecendo 90 e $135 \mathrm{~kg} \mathrm{ha}^{-1}$ de $\mathrm{N}$ e $\mathrm{K}_{2} \mathrm{O}$, respectivamente, visando produtividade aproximada de $100 \mathrm{t} \mathrm{ha}^{-1}$ de colmos. 
Para controle de ervas daninhas foram feitas aplicações de mistura entre clomazona e ametrina em pré-emergência.

\subsection{Delineamento experimental e tratamentos}

As parcelas experimentais constituíram-se por sete linhas com 10 metros de comprimento. Para determinações de atributos químicos do solo, avaliação do estado nutricional, produtividade e qualidade tecnológica da cana-de-açúcar, foi empregado o delineamento experimental em blocos casualizados com 12 cultivares (Anexo A) e cinco repetições.

O delineamento experimental para avaliação de atributos físicos do solo foi em parcelas sub-divididas. No estudo dos atributos físicos foram considerados dois cultivares (RB83 5089 e RB83 5486), três profundidades no perfil (0-20, 20-40 e 40-100 cm) e três repetições. Distribuição de raízes no perfil e desenvolvimento radicular a partir da brotação de soqueiras foram avaliados com base no delineamento em parcelas sub-subdivididas.

A distribuição radicular, tanto no LVA quanto no NV, foi avaliada para dois cultivares (RB83 5089 e RB83 5486), três distâncias horizontais a partir das linhas de cana (0-18, 18-36, 36-54 cm no LVA e 0-23, 23-46, 46-69 cm no NV) e três repetições. Entretanto, no LVA foram consideradas quatro profundidades no perfil do solo (0-18, 18-36, 36-54, 54-72 cm) e no NV foram consideradas somente três profundidades (0-23, 23-46, 46-69 cm). O desenvolvimento radicular a partir da brotação de soqueiras foi avaliado para dois cultivares (RB83 5089 e RB83 5486), quatro profundidades no perfil (0-10, 10-20, 20-30 e 30-40 cm), quatro épocas de amostragem (10, 40, 70 e 160 dias a partir da brotação das soqueiras) e três repetições. 


\subsection{Avaliação da fertilidade do solo e do estado nutricional da cultura}

Após colheita da safra 2001/2002 foi realizada amostragem de solo em cada parcela experimental para os 12 cultivares. Coletaram-se amostras nas profundidades de 0-20 e 20-40 cm. Cada amostra foi composta por três sub-amostras que foram coletadas por meio de trado holandês, armazenadas em sacos plásticos e identificadas. O preparo das amostras e as análises para determinação dos teores de macro e micronutrientes foram realizadas de acordo com metodologias descritas em Raij et al. (2001). A determinação dos teores de enxofre no solo foi realizada segundo metodologia descrita por Vitti (1988).

A avaliação do estado nutricional da cultura foi feita para as safras 2002/2003 e 2003/2004. Na fase de máximo crescimento da cultura (aproximadamente quatro meses após início da brotação das soqueiras) coletaram-se amostras da folha +3 conforme 0 sistema Kuijper, segundo Gallo (1962). Foram separados os 20 cm centrais da lâmina foliar, removendo-se a nervura central. As amostras foram secas em estufa e moídas para posterior determinação de macro e micronutrientes (Malavolta et al., 1997).

Por ocasião da colheita da safra 2003/2004, foi feita coleta de amostras de colmos nas quais foram determinados os teores de macronutrientes para que posteriormente, com base nos resultados de produtividade, fosse determinada a extração de macronutrientes pelos colmos.

\subsection{Curva de retenção de água, macroporosidade, densidade do solo e resistência à penetração (RP)}

Para avaliação da curva de retenção de água, macroporosidade e densidade do solo coletaram-se 18 amostras indeformadas em cada experimento. As amostras foram coletadas em fase intermediária de desenvolvimento das cana-de-açúcar para a safra 2002/2003, em três perfis de solo para os cultivares RB83 5486 e RB83 5089. A amostragem foi direcionada, considerando análise prévia do perfil de solo na qual 
verificaram-se diferentes condições de compactação na entrelinha da cultura nas profundidades de 0-20, 20-40 e 40-100 cm.

As amostras foram coletadas em anéis metálicos $(5 \mathrm{~cm}$ de diâmetro e $3 \mathrm{~cm}$ de altura). No laboratório, a saturação das amostras foi feita a partir da adição lenta de água. Após saturação, as amostras foram pesadas, colocadas em mesa de tensão adaptada de Topp \& Zebchuk (1979) e submetidas às pressões de 0,01; 0,04; 0,05; 0,06; 0,1 atm. Após pressão de 0,1 atm, as amostras foram colocadas em câmaras de pressão (Klute, 1986) e submetidas às pressões de 0,33; 0,7; 1,0 e 15 atm.

A determinação da resistência à penetração (RP) foi feita em cada uma das amostras indeformadas, com três repetições por amostra. Para medidas da RP foi utilizado penetrômetro desenvolvido no laboratório de física do solo da ESALQ/USP, cujos critérios de funcionamento são citados por Leão (2002). Valores de RP foram obtidos em kgf e posteriormente transformados em MPa. A média aritmética dos valores foi calculada para cada ensaio e para as três repetições realizadas em cada amostra.

Após medidas de RP, as amostras indeformadas foram pesadas e colocadas em estufa a $105{ }^{\circ} \mathrm{C}$ durante 24 horas para determinação da umidade gravimétrica $(\theta \mathrm{g}$ ) (Gardner, 1986) e densidade do solo (Ds) (Blake \& Hartge, 1986). A umidade volumétrica $(\theta \mathrm{v})$ foi obtida a partir da multiplicação da umidade gravimétrica pela densidade do solo em $\mathrm{g} \mathrm{cm}^{-3}$ (Libardi, 2000).

\subsection{Avaliação da distribuição do sistema radicular}

Na fase intermediária de desenvolvimento das touceiras para a safra 2002/2003, a distribuição do sistema radicular foi estudada nos cultivares RB83 5089 e RB83 5486 tanto no NV quanto no LVA. O método utilizado para tal avaliação foi o da trincheira ou parede do perfil.

No NV foram abertas, manualmente, três trincheiras para cada um dos cultivares acima mencionados, nas dimensões de 1,40 x 1,50 x 1,00 m. No LVA, as trincheiras apresentaram as dimensões de 1,10 x 1,50 x 1,00 m. A parede utilizada para estudo das 
raízes foi a transversal às linhas de cana, buscando-se verificar o efeito da passagem de máquinas nas entrelinhas da cultura (Figura 2).

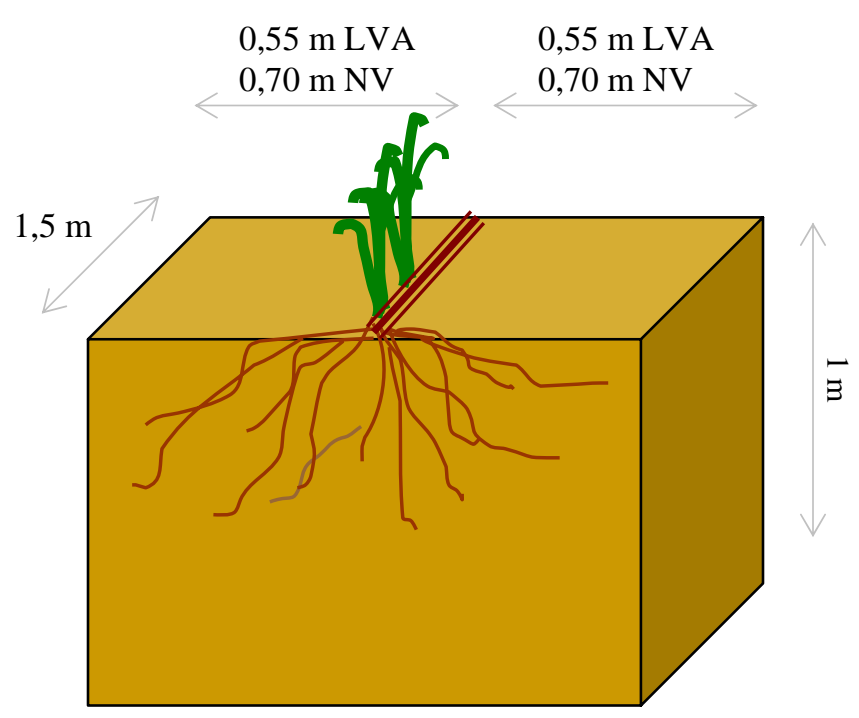

Figura 2 - Esquema das trincheiras e da posição utilizada para avaliação do sistema radicular

Após abertura das trincheiras, foi feito preparo cuidadoso do perfil em três distâncias entre parede da trincheira e touceira de cana: 30, 20 e 10 cm. Para cada distância, foi realizado corte para deixar as raízes rentes à parede para, em seguida, promover a exposição das raízes no perfil com rolo escarificador (Figura 3). As raízes expostas foram pintadas individualmente com tinta látex branca, com intuito de melhorar contraste entre raízes e solo. Após pintura, foram obtidas imagens com câmera fotográfica digital.

A área de perfil analisada no NV foi de 1,40 m de largura, que corresponde ao espaçamento da cultura para esse solo (0,70 m de cada lado) e 0,69 m de profundidade. No LVA, a área foi de $1,10 \mathrm{~m}$ de largura (0,55 m de cada lado) e 0,72 m de profundidade. As imagens foram obtidas em quadrículas previamente identificadas e que 
apresentaram dimensões de 0,18 x 0,18 m (total de 24 quadrículas por perfil no LVA), e dimensões de 0,23 x 0,23 m (total de 18 quadrículas por perfil) no NV (Figuras 4 e 5).

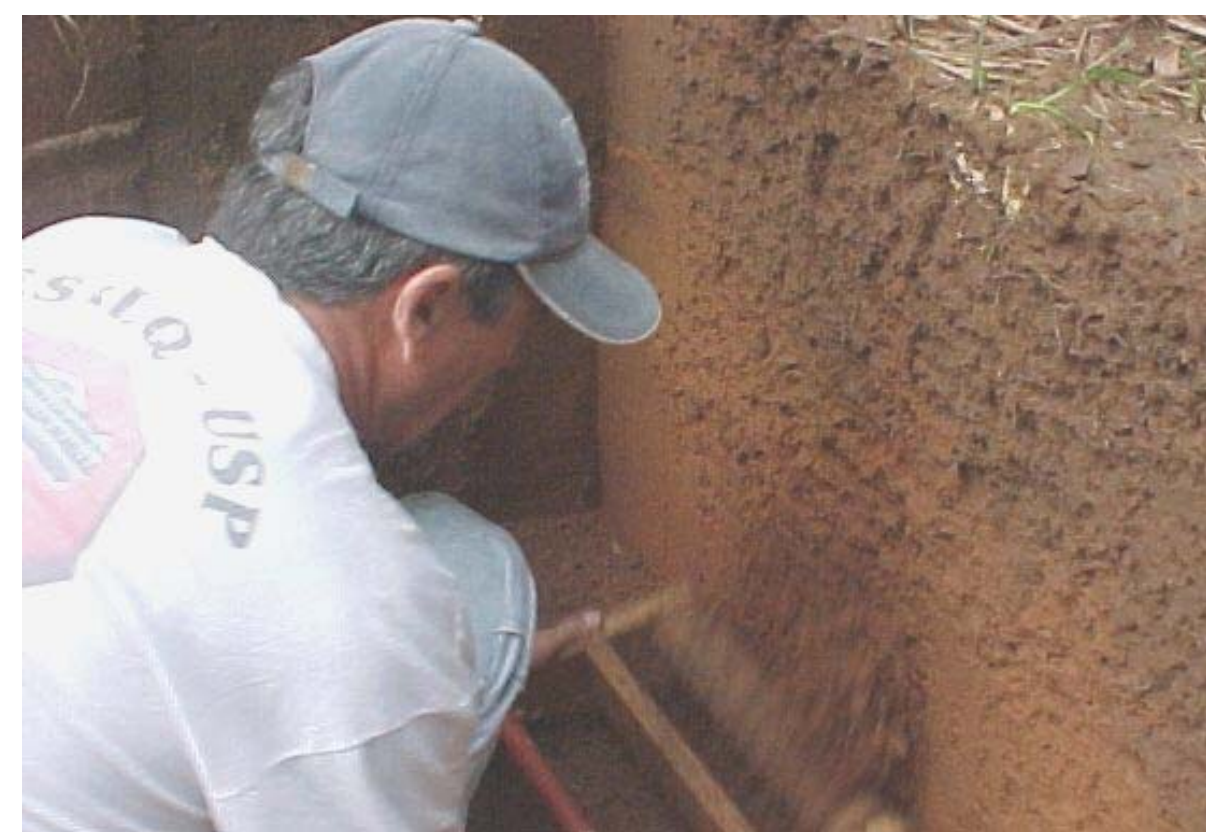

Figura 3 - Escarificação para exposição das raízes de cana no perfil do solo

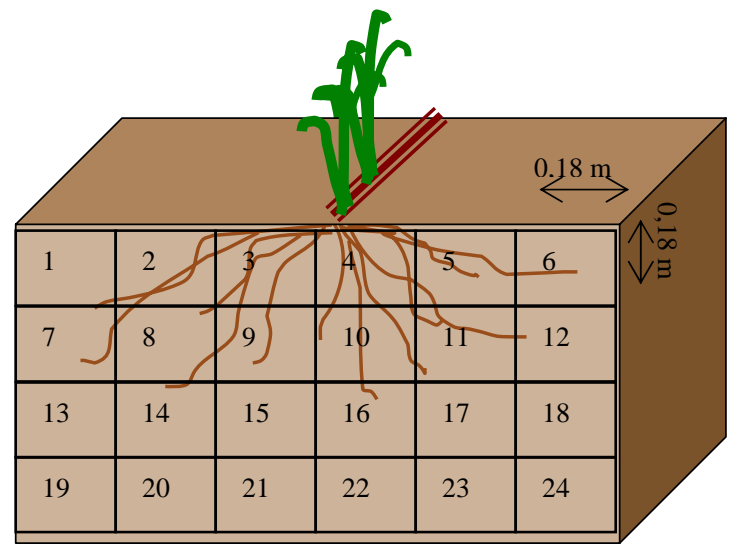

Figura 4 - Número e dimensões das quadrículas em perfil do LVA

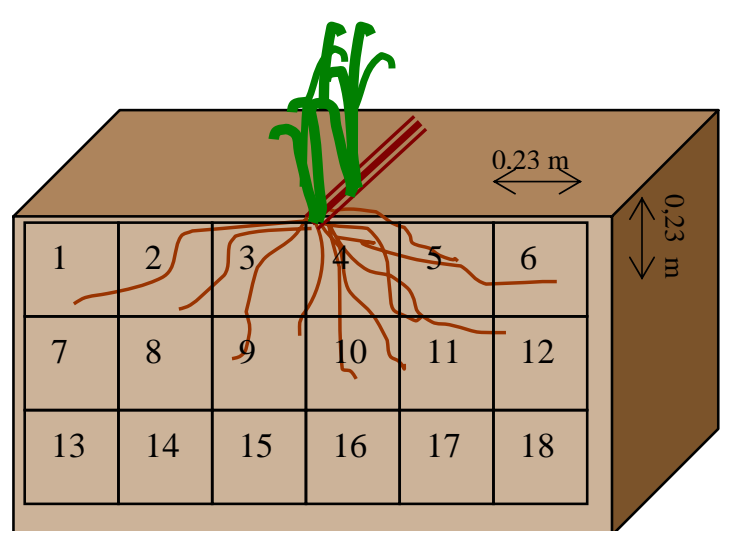

Figura 5 - Número e dimensões das quadrículas em perfil do NV 
As imagens de raízes foram analisadas com o software SIARCS, obtendo-se valores de comprimento de raízes. Resultados de comprimento radicular provenientes de imagens obtidas a três distâncias entre parede do perfil e touceira de cana (30, 20 e 10 cm) foram somados, para reduzir efeitos da variabilidade nos procedimentos estatísticos.

\subsection{Dinâmica radicular a partir da brotação das soqueiras}

Para estudo da dinâmica de raízes a partir da brotação das soqueiras da safra 2003/2004, foram coletadas amostras em quatro épocas (10, 40, 70 e 160 dias após início da brotação). As raízes foram coletadas em duplicata, por meio de sonda $(4,5 \mathrm{~cm}$ de diâmetro interno e $100 \mathrm{~cm}$ de comprimento), em quatro profundidades (0-10, 10-20, 20-30 e 30-40 cm) e três repetições para cada cultivar de cana-de-açúcar (RB83 5089 e RB83 5486), tanto no NV quanto no LVA. Como local de amostragem, foi padronizado $20 \mathrm{~cm}$ de distância do lado direito das touceiras.

As amostras foram armazenadas em sacos plásticos, identificadas e colocadas em caixas de isopor com gelo. Uma parte das amostras foi destinada aos testes de vitalidade radicular, enquanto que a outra parte foi destinada às análises morfológicas. Para os testes de vitalidade, as amostras foram lavadas e separadas do solo com máxima rapidez e congeladas em nitrogênio líquido, permanecendo preservadas em freezer $\left(-80{ }^{\circ} \mathrm{C}\right)$ até realização das análises, seguindo metodologia adaptada de Ruf \& Brunner (2003).

A outra parte das amostras foi lavada e armazenada em tubos plásticos contendo solução de etanol 70\%. O material foi mantido em câmara fria até realização das análises. O software WinRHIZO Basic (Regent) foi utilizado para analisar morfologicamente as raízes lavadas a partir de imagens scaneadas (Epson Scanner). Os atributos morfológicos determinados foram: comprimento radicular, classes de diâmetro, diâmetro médio e densidade radicular. 


\subsection{Análises estatísticas}

As análises estatísticas de atributos químicos e físicos do solo, teor de nutrientes nas folhas, produtividade da cultura, atributos de qualidade do caldo e atributos radiculares foram feitas com o programa Genstat (versão 7.1 NAG. Ltda.). Análise de variância $(\alpha=0,05)$ foi conduzida utilizando o procedimento ANOVA para os delineamentos em blocos casualizados, parcelas sub-divididas e parcelas subsubdivididas.

No delineamento em blocos casualizados, a comparação de médias foi feita a partir do teste de Tukey. Os atributos analisados estatisticamente a partir do delineamento parcela sub-dividida e sub-subdividida apresentaram separação de médias pelo procedimento da diferença mínima significativa (PSE-diff). No estudo da distribuição de raízes no perfil, contrastes ortogonais foram utilizados para verificar diferenças entre os dois lados das touceiras de cana-de-açúcar. 


\section{RESULTADOS E DISCUSSÃO}

\subsection{Avaliação da fertilidade do solo e do estado nutricional da cultura}

\subsubsection{Fertilidade do solo - Atributos químicos}

As principais diferenças quanto aos atributos químicos do solo ocorreram no pH e na acidez potencial ( $\mathrm{H}+\mathrm{Al})$. A concentração de íons hidrogênio e a acidez potencial são apresentadas na Figura 6 na qual constata-se que, nas profundidades de 0-20 cm e 20-40 cm, valores de pH foram menores com o cultivar RB83 5089 no NV. A diferença de pH na profundidade de 0-20 cm foi refletida na acidez potencial, conforme já descrito por outros autores (Quaggio et al., 1985; Fernandes et al., 2002). A acidez potencial foi maior mediante menores valores de $\mathrm{pH}$.

No LVA, apesar de não constatada diferença estatística entre tratamentos, o pH foi menor quando o solo foi cultivado com RB83 5486. Tal resultado aponta para a possibilidade de que esse cultivar explorou mais o LVA do que o $\mathrm{NV}$ em termos de absorção de nutrientes. Para reforçar essa possibilidade vale ressaltar que o menor pH observado no LVA também está associado à maior acidez potencial. Além disso, a amplitude de variação no $\mathrm{pH}$ foi maior no LVA e menor no $\mathrm{NV}$, o que pode ser explicado pela maior capacidade de troca de cátions do NV que confere a esse solo maior poder tampão (Raij, 1991).

Estudando atributos químicos, alguns autores constataram grande variabilidade em solos de áreas visualmente uniformes. Entretanto, menor variabilidade foi verificada para valores de $\mathrm{pH}$, atribuindo diferenças aos tratamentos (Silveira et al., 2000; Vasconcelos, 2002).Variações no pH da solução do solo podem ocorrer em função da 
atividade radicular diferenciada, que modifica inicialmente a rizosfera e pode, inclusive, alterar o pH da solução do solo. Segundo Marschner \& Hömheld (1996), o pH da rizosfera pode diferir do pH da solução do solo em mais de duas unidades.

Na rizosfera, a variação no $\mathrm{pH}$ é determinada por fatores intrínsecos à planta, enquanto que o grau e extensão de variação são determinados pela superfície radicular. Fatores relacionados à planta e ao solo definem se a mudança no $\mathrm{pH}$ será verificada não só na rizosfera, mas também na solução do solo (Marschner \& Hömheld, 1996).

$\mathrm{O}$ pH inicial e poder tampão são definidos como fatores relacionados ao solo. Como o poder tampão é menor em solos com pH próximo a 5, mudanças no $\mathrm{pH}$ em função da atividade radicular são mais verificadas em solos com pH inicial não muito maior ou menor que 5 (Nye, 1981; Schaller, 1987).

Como fatores que influenciam a mudança no $\mathrm{pH}$ da rizosfera e que estão ligados à planta, Marschner \& Hömheld (1996) citam a excreção ou reabsorção de $\mathrm{H}^{+}$ou $\mathrm{HCO}_{3}{ }^{-}$, a liberação de $\mathrm{CO}_{2}$ resultante da respiração radicular e o efluxo de exsudados de baixo peso molecular (ácidos orgânicos e aminoácidos). Em solos com aeração deficiente, a liberação de $\mathrm{CO}_{2}$ apresenta mais importância no processo de modificação do $\mathrm{pH}$ da rizosfera (Nye, 1981).

Segundo Schachtman (1998) e Marschner (1995) já foram encontradas alterações entre cultivares quanto à fisiologia e morfologia do sistema radicular, mediante crescimento de plantas em solos pobres em fósforo. Tais alteraçõs aumentariam a excreção de ácidos orgânicos, a expressão do transportador de fósforo inorgânico e, além disso, reduziriam o pH da rizosfera (Johnson et al., 1996; Goldstain et al., 1998; Gahoonia \& Nielson, 1992). É interessante observar que estudos realizados nas décadas de 70 e 80 (Bittencourt et al., 1978; Manhães \& Glória, 1980) confirmaram boa correlação do extrator $\mathrm{H}_{2} \mathrm{SO}_{4}$ 0,5 $\mathrm{N}$ e a disponibilidade de fósforo para a cana-de-açúcar.

Marschner \& Hömheld (1996) mencionam que a principal causa de mudança no pH da rizosfera é a liberação de $\mathrm{H}^{+}$(ou $\mathrm{HCO}_{3}{ }^{-}$ou $\mathrm{OH}^{-}$) proporcionada pelas diferenças entre absorção catiônica e aniônica. Diversos estudos mostraram que plantas acidificaram o solo a partir da liberação de protóns pelo sistema radicular quando a absorção de cátions foi superior à absorção de ânions (Beusichem, 1981; Jarvis \& Hatch, 
1985; Liu \& Lund, 1989; McLay et al., 1997; Tang \& Rengel, 2003). A forma em que o nitrogênio é absorvido pelas plantas $\left(\mathrm{NO}_{3}{ }^{-}\right.$ou $\left.\mathrm{NH}_{4}{ }^{+}\right)$parece ser mais relevante nos processos de acidificação da rizosfera (Marschner \& Hömheld, 1986).

Os menores valores de pH encontrados no NV com o RB83 5089 poderiam ser decorrentes da maior atividade radicular na absorção de nutrientes desse cultivar. Entretanto, não é possível afirmar que a absorção de nutrientes na forma catiônica prevaleceu sobre a forma aniônica, apesar da maior extração de potássio por colmos no cultivar RB83 5089 nesse solo (Figura 8).

Diferenças genotípicas já foram observadas quanto à alteração no pH em função da atividade radicular em um determinado solo, inclusive com a mesma forma de suprimento de nitrogênio (Marschner \& Hömheld, 1996). Vasconcelos (2002) verificou redução no pH do solo com diferentes cultivares de cana-de-açúcar. No entanto, o autor relacionou a mudança no pH com a adição de fertilizantes.

Estudando raízes de cana-de-açúcar em diferentes sistemas de colheita, Vasconcelos (2002) detectou diferenças na variabilidade espacial dos atributos químicos do solo, causadas por características pedogenéticas e pelas diferenças na dinâmica de absorção de nutrientes de diferentes cultivares de cana-de-açúcar.

Não foram encontradas diferenças para outros atributos químicos do solo que pudessem indicar influência do sistema radicular dos cultivares avaliados. Não houve diferença entre cultivares para teores de micronutrientes no solo nas duas profundidades estudas (Anexos B, C, D e E). Para explicar a ausência de resposta aos tratamentos em relação ao teor de nutrientes no solo, deve-se considerar o pequeno impacto da quantidade absorvida pelas plantas em relação às unidades de medida usadas para quantificar nutrientes no solo. 


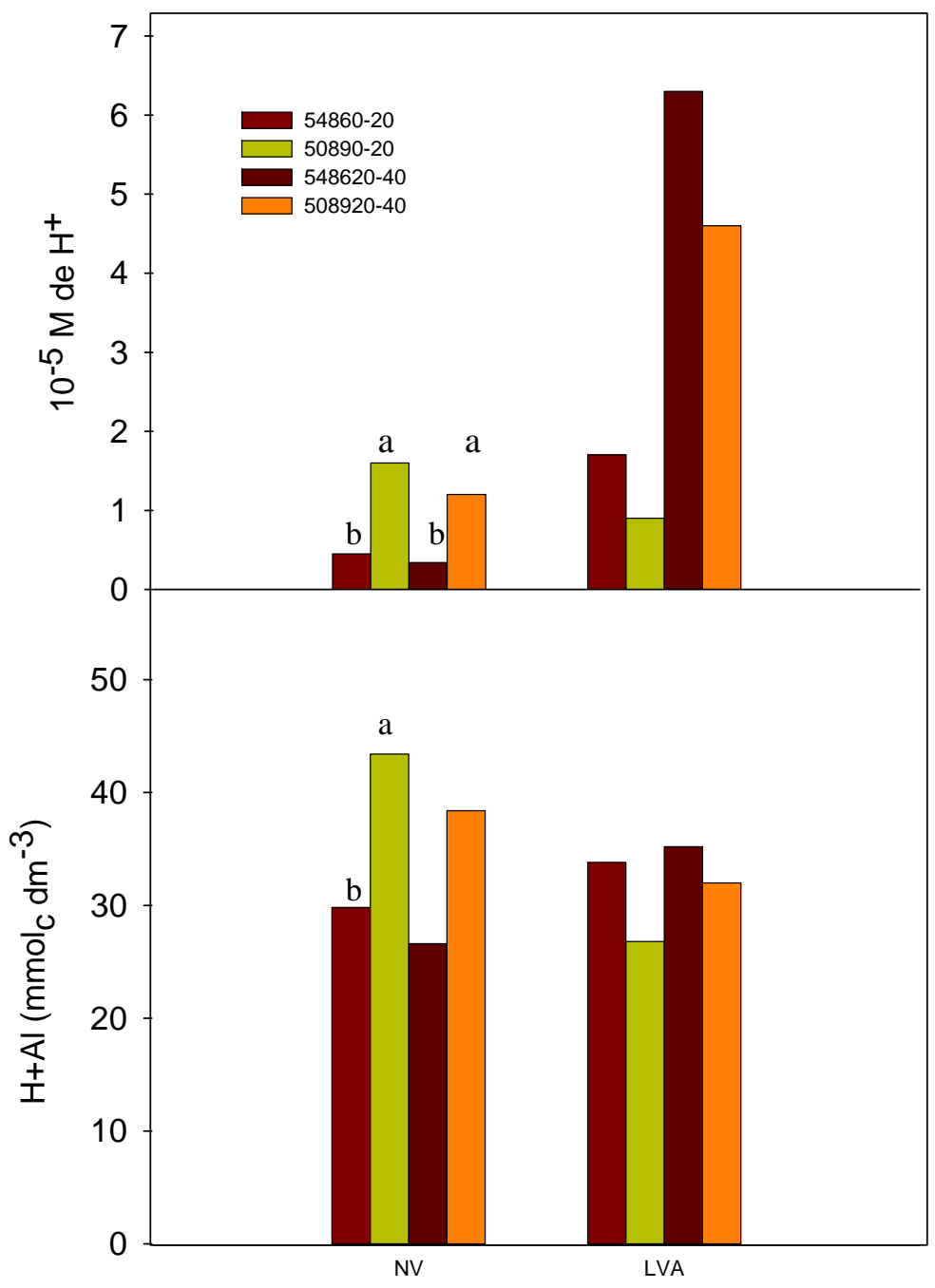

Figura 6 - Concentração de íons $\mathrm{H}^{+}$e acidez potencial $(\mathrm{H}+\mathrm{Al})$ em duas profundidades dos solos NV e LVA com os cultivares de cana-de-açúcar RB83 5089 e RB83 5486 (amostras coletadas ao final da safra 2001/2002) 


\subsubsection{Estado nutricional da cultura - Teor foliar, conteúdo e extração por colmos}

Na Figura 7 são apresentados teores de macronutrientes e micronutrientes no tecido foliar dos cultivares de cana-de-açúcar RB83 5486 e RB83 5089, coletado nas safras 2002/2003 e 2003/2004 nos solos LVA e NV.

Nos resultados referentes à safra 2002/2003, foi verificada diferença entre cultivares quanto ao teor foliar de macronutrientes nos dois solos, com exceção para teores de enxofre (S) no LVA e fósforo (P) no NV.

O cultivar RB83 5486 apresentou maior teor foliar de potássio (K) nos dois solos, apresentando também tendência de maior teor de S. Já o cultivar RB83 5089 teve maior teor foliar de nitrogênio $(\mathrm{N})$, cálcio $(\mathrm{Ca})$ e magnésio $(\mathrm{Mg})$. Porém, diferença no teor foliar de P, com maior valor para RB83 5089, somente foi verificada no LVA.

Na safra 2003/2004 os resultados indicaram que, no LVA, o cultivar RB83 5089 apresentou maiores teores de N, P e Ca, enquanto que RB83 5486 apresentou maior teor de S. No NV, o cultivar RB83 5089 apresentou maiores teores de N, Ca e Mg, já o RB83 5486 apresentou maior teor foliar de S.

A diferença no teor foliar de $\mathrm{P}$ entre cultivares foi menor no NV do que no LVA. A maior fixação do P no solo com teor de argila mais elevado (NV) resultou em menor disponibilidade do nutriente, contribuindo com o teor foliar semelhante entre os cultivares estudados. No LVA, em função do menor teor de argila, houve menor fixação de $P$, que proporcionou maior disponibilidade do nutriente às plantas, resultando em diferença entre cultivares. Estudos realizados por Syers et al. (1971) e Thomazi (1988) apontam o teor de argila dos solos como um dos fatores que mais influenciam a capacidade de fixação e, conseqüentemente, a disponibilidade de fósforo.

Com relação aos teores de micronutrientes encontrados nas folhas de cana-deaçúcar, as principais diferenças foram verificadas em amostras coletadas na quinta soca. Houve diferença no teor de ferro (Fe), com maiores valores observados para o cultivar RB83 5486 no LVA. No NV, houve diferença no teor de Mn com maior valor para o RB83 5089. A diferença de teores entre cultivares pode ser explicada pelo menor $\mathrm{pH}$ encontrado no LVA mediante cultivo com RB83 5486 e no NV com o RB83 5089. Raij (1991) menciona que mediante menor pH há aumento na disponibilidade de Fe e Mn. 
Comparando teores de nutrientes resultantes da análise do tecido foliar com os valores considerados adequados por Malavolta (1994) para a cultura da cana-de-açúcar, constatou-se teor elevado de potássio na safra 2002/2003, enquanto que teores de cálcio e enxofre estiveram abaixo dos valores considerados adequados. Na safra 2003/2004, teores de potássio não foram tão elevados como na safra anterior.

A prévia aplicação de vinhaça nas áreas experimentais causou desbalanceamento na relação de bases trocáveis (Ca:Mg:K), aumentando a disponibilidade de K em relação às outras bases. A elevada absorção de $\mathrm{K}$ prejudicou a absorção de Ca e Mg, o que pode ser confirmado pelo maior teor foliar de K e menores teores de Ca e Mg para o cultivar RB83 5486. Considerando a última safra (2001/2002) em que houve aplicação de vinhaça, houve maior efeito residual na safra 2002/2003 do que na safra 2003/2004. 


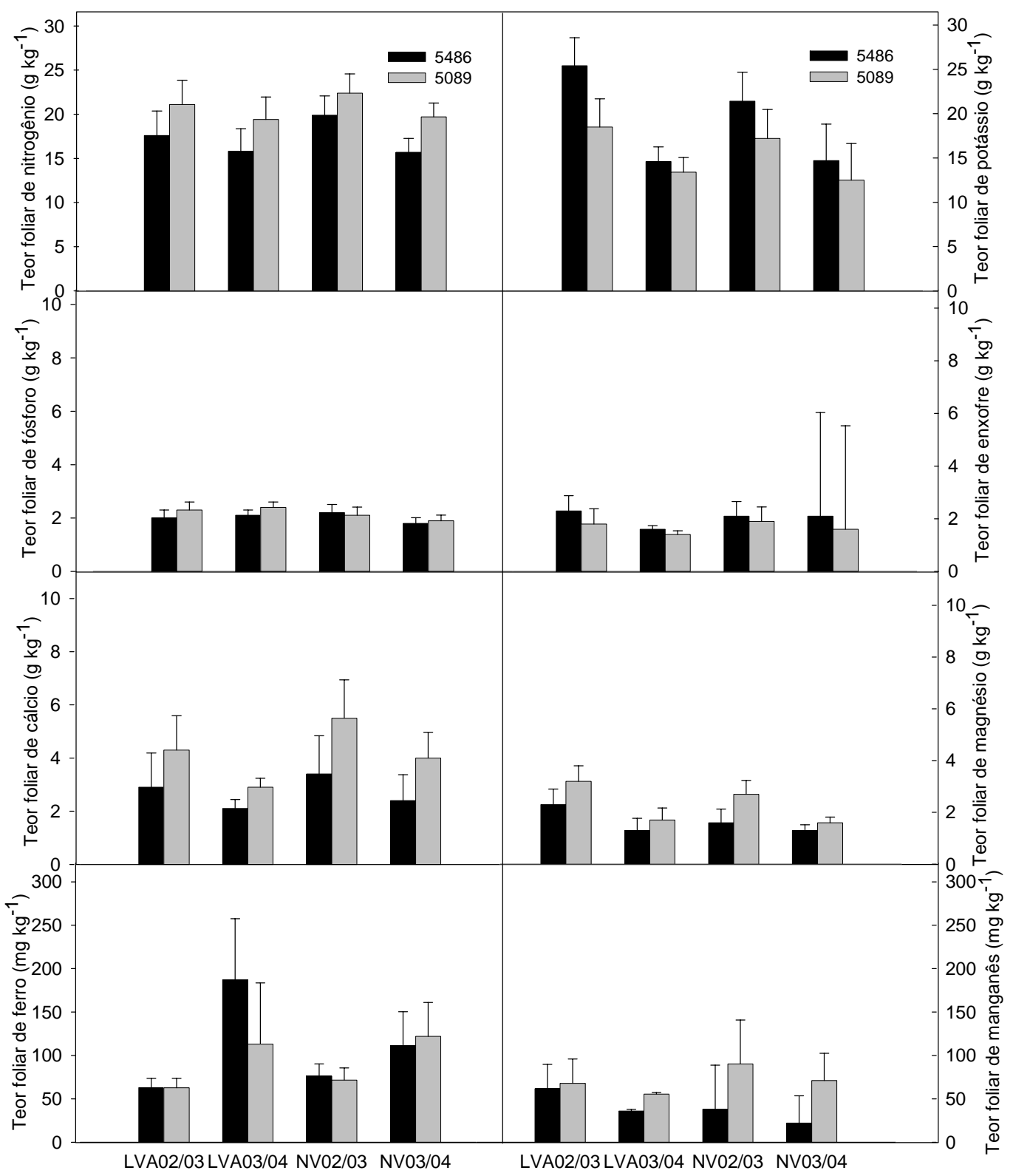

Figura 7 - Teor foliar de macronutrientes e micronutrientes nas safras 2002/2003 e 2003/2004 para dois cultivares de cana-de-açúcar plantados no solos LVA e NV 
Na safra 2002/2003 foi encontrado maior teor de K nas folhas do cultivar RB83 5486. Caso esse teor foliar de K tivesse refletido em maior extração do elemento por colmos na referida safra, seriam confirmados os resultados de Coleti et al. (2002) em que o cultivar, quando comparado com o SP 81-3250, apresentou maior extração desse macronutriente, justificando sua elevada aptidão industrial para produção de álcool.

Teores adequados de potássio aumentam a sacarose na cana-de-açúcar (Lopes \& Landrau, 1952; Hauck \& Dickinson, 1954). Por outro lado, a maior absorção de potássio pela planta aumenta o teor de cinzas do caldo. O maior teor de cinzas dificulta o processo de cristalização, sendo um efeito negativo na fabricação de açúcar. Porém, os constituintes das cinzas do caldo agem como fonte de nutrientes para o processo fermentativo, aumentando a velocidade de desdobramento dos açúcares em álcool, o que favorece a fabricação de etanol.

Na Tabela 4 é apresentado o conteúdo de macronutrientes nos colmos. Não houve diferença entre os cultivares tanto no LVA quanto no NV. Gomes (2003) não verificou diferença no conteúdo de N e P nos colmos para os cultivares RB83 5486 e RB83 5089 nos solos LVA e NV, em três cortes. Entretanto, o mesmo autor constatou maior conteúdo de K para o cultivar RB83 5089 em primeira soca no NV.

No LVA, a relação N:K foi de 1,1:1,0 para o cultivar RB83 5486 e 1,4:1,0 para o RB83 5089, contrariando resultados de Silva \& Casagrande (1983) em que houve menor relação $\mathrm{N}: \mathrm{K}$, representando maior extração de $\mathrm{K}$ em relação ao $\mathrm{N}$. As relações $\mathrm{N}: \mathrm{K}$ já verificadas para cana-de-açúcar foram de 0,7:1,0 à 1,8:1,0 (Orlando Filho et al., 1980), 1,0:1,0 à 0,7:1,0 (Coleti et al., 2002) e 0,36:1,0 à 0,67:1,0 (Gomes, 2003). No NV, a relação N:K foi 0,41:1,0 e 0,37:1,0 para os cultivares RB83 5486 e RB83 5089, respectivamente. Coleti et al. (2002) encontraram menor relação N:K para o cultivar RB83 5486, relacionando a maior extração de K pelo cultivar com maior aptidão agroindustrial. 
Tabela 4. Conteúdo de macronutrientes nos colmos dos cultivares de cana-de-açúcar RB83 5486 e RB83 5089 no LVA e NV (safra 2003/2004)

\begin{tabular}{ccccccc}
\hline Cultivar & $\mathrm{N}$ & $\mathrm{P}$ & $\mathrm{K}$ & $\mathrm{Ca}$ & $\mathrm{Mg}$ & $\mathrm{S}$ \\
& \multicolumn{7}{c}{$\mathrm{kg} \mathrm{Mg}^{-1}$} \\
\hline \multicolumn{7}{c}{ Latossolo Vermelho-Amarelo Distrófico psamítico (LVA) } \\
RB 83 5486 & 5,1 & 0,7 & 4,5 & 0,5 & 0,3 & 0,5 \\
RB83 5089 & 8,8 & 0,8 & 6,2 & 0,5 & 0,3 & 0,5 \\
DMS & 4,1 & 0,2 & 1,8 & 0,2 & 0,1 & 0,1 \\
CV (\%) & 34 & 18 & 19 & 24,5 & 25 & 16 \\
& Nitossolo Vermelho Eutroférrico latossólico (NV) & \\
RB 83 5486 & 4,1 & 0,4 & 9,9 & 0,6 & 0,4 & 1,0 \\
RB83 5089 & 3,9 & 0,4 & 10,5 & 0,6 & 0,5 & 0,9 \\
DMS & 0,4 & 0,1 & 2,1 & 0,2 & 0,1 & 0,4 \\
CV (\%) & 6,0 & 12 & 12 & 18 & 14 & 27 \\
\hline
\end{tabular}

É importante ponderar que o teor foliar e o conteúdo de nutrientes encontrados nos colmos podem apresentar efeito de diluição, ou seja, os valores podem ser reduzidos devido à elevada produção de massa foliar e de colmos. Dessa forma, torna-se importante determinar a quantidade de nutrientes exportada, considerando a produção de colmos por hectare.

A Figura 8 ilustra a extração de nutrientes por colmos para a safra 2003/2004. Os nutrientes mais exportados pela cultura foram $\mathrm{N}$ e $\mathrm{K}$ nos dois solos, confirmando observações feitas por Silva e Casagrande (1983). No LVA houve maior extração de N para o cultivar RB83 5089, já no NV o mesmo cultivar apresentou maior extração de K. Provavelmente a maior extração de K no NV tenha ocorrido em função das menores perdas por lixiviação, já que este solo apresenta maior CTC quando comparado ao LVA. Gomes (2003) observou maiores teores de K nos colmos de cultivares de cana-de-açúcar desenvolvidos em NV devido aos maiores teores do nutriente no solo e à maior CTC que reduziu perdas por lixiviação. 
É provável que tais resultados devam-se às características contrastantes dos solos. No LVA a dinâmica do potássio foi mais intensa, com maior lixiviação que tornou o nutriente menos disponível às plantas. No NV, as características do solo promoveram menor lixiviação de $\mathrm{K}$ que esteve em solução em maior quantidade, disponível às plantas.

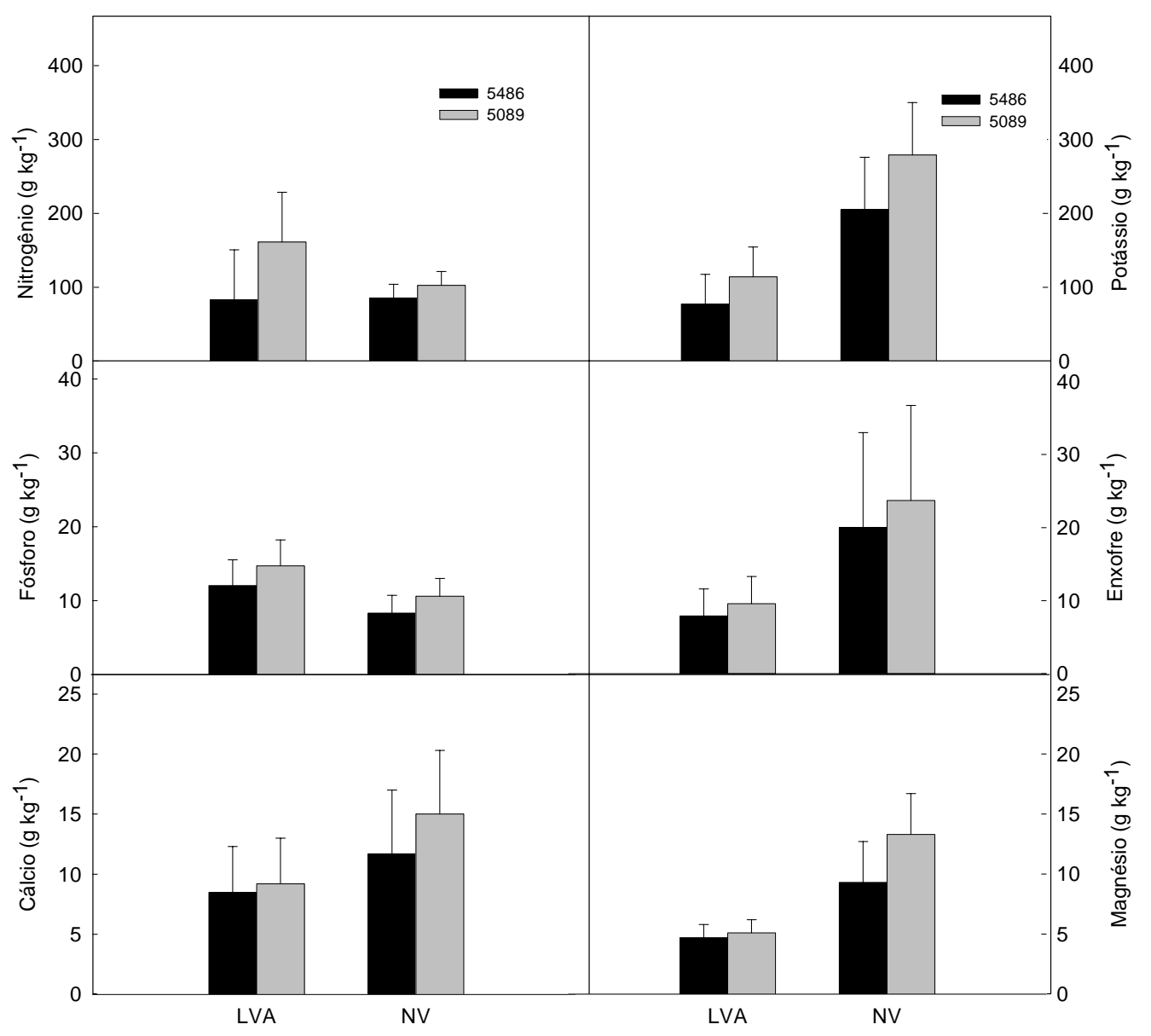

Figura 8 - Extração de macronutrientes por colmos para os cultivares RB83 5486 e RB83 5089 nos solos LVA e NV 
Do ponto de vista econômico, é importante determinar a quantidade de nutrientes necessária à produção de açúcar, pois, se um cultivar apresenta elevada produção de açúcar decorrente de maior produção de colmos, extraindo maior quantidade de nutrientes, o mesmo poderia ser economicamente menos viável. Na Tabela 5 são apresentadas as quantidade de macronutrientes relacionadas à produção de açúcar.

Tabela 5. Quantidade de macronutrientes em gramas (g) para produção de 1 kg de ATR nos cultivares RB83 5486 e RB83 5089 nos solos LVA e NV (safra 2003/2004)

\begin{tabular}{ccccccc}
\hline Cultivar & N & P & K & Ca & Mg & S \\
\multicolumn{7}{c}{$\mathrm{g} \mathrm{kg}^{-1}$} \\
LB 83 5486 & 0,03 b & 0,004 & 0,03 b & 0,003 & 0,002 & 0,003 b \\
RB83 5089 & 0,06 a & 0,005 & 0,04 a & 0,003 & 0,002 & 0,004 a \\
DMS & 0,03 & 0,002 & 0,01 & 0,001 & 0,0009 & 0,001 \\
CV (\%) & 34 & 20 & 21 & 24 & 27 & 16 \\
& Nitossolo Vermelho Eutroférrico latossólico (NV) & \\
RB 83 5486 & 0,04 a & 0,004 a & 0,1 & 0,005 & 0,004 & 0,01 \\
RB83 5089 & 0,03 b & 0,003 b & 0,09 & 0,005 & 0,004 & 0,007 \\
DMS & 0,007 & 0,001 & 0,02 & 0,001 & 0,001 & 0,004 \\
CV (\%) & 11 & 15 & 12 & 17 & 13 & 26 \\
\hline
\end{tabular}

Os resultados apresentados na Tabela 5 indicam que, para produção de um quilograma de ATR, no LVA o cultivar RB83 5089 precisou de maiores quantidades de N, K e S. Já no NV, o cultivar RB83 5486 necessitou de maiores quantidade de N e P que o RB83 5089 para produção de açúcar, o que sugere maior eficiência do cultivar RB83 5486 no LVA. 


\subsection{Curva de retenção de água, densidade, resistência à penetração e porosidade do solo}

Na Figura 9, na qual o potencial de água é apresentado em escala logarítmica, verifica-se o diferencial de água armazenada entre os dois solos. A figura também ilustra a diferença ocorrida na retenção de água para as profundidades avaliadas. A retenção de água foi maior no NV que também apresentou diferença na retenção entre profundidades. A partir da tensão de $1 \mathrm{kPa}$, a retenção de água no $\mathrm{NV}$ foi menor nos primeiros 20 centímetros de profundidade.

A umidade de saturação, tanto no $\mathrm{NV}$ quanto no LVA, foi menor na profundidade 20-40 cm. A umidade de saturação é menor em camadas compactadas devido à menor porosidade total (Reichardt, 1996).

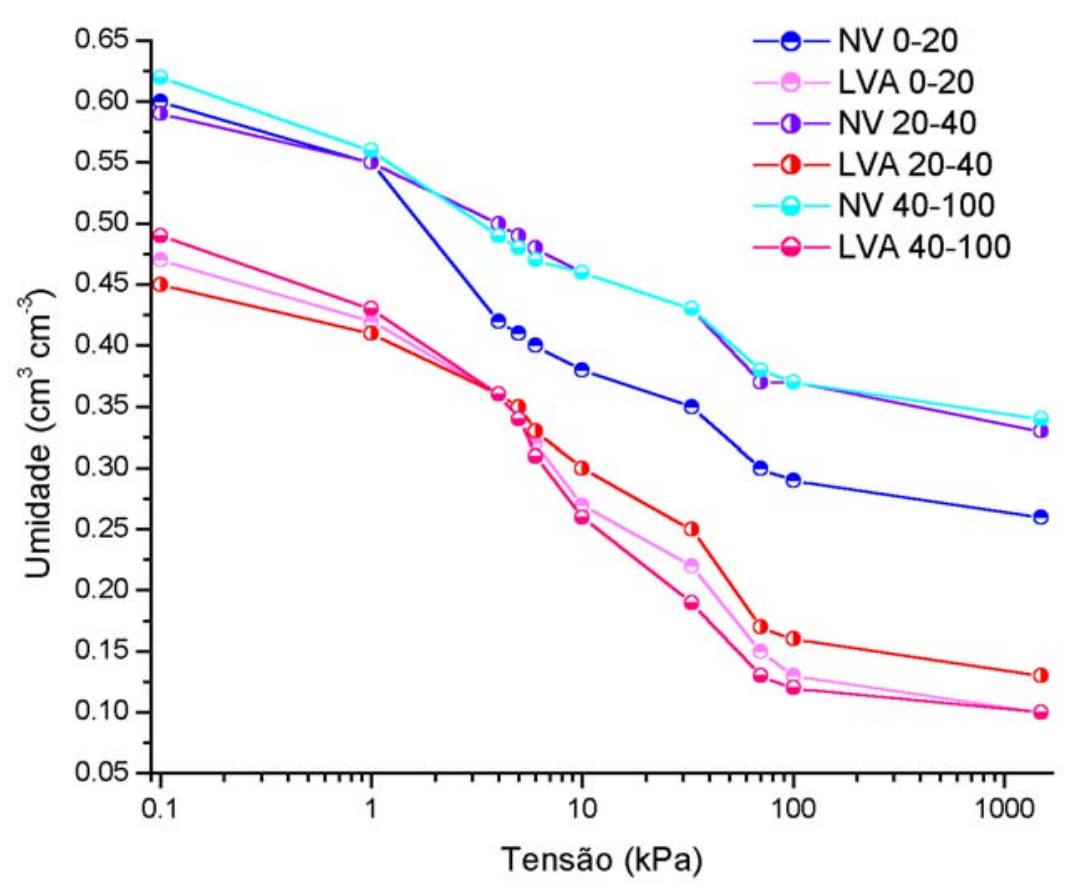

Figura 9 - Curva de retenção de água para três profundidades dos solos NV e LVA 
No NV, a profundidade 20-40 cm caracterizou a camada de impedimento físico, apresentando maiores valores de densidade do solo e resistência à penetração. Na mesma camada foram encontradas menores porcentagens de porosidade total e de macroporos, como resultado da compactação (Tabela 6). A menor retenção de água a partir da tensão de $1 \mathrm{kPa}$, na profundidade 0-20 cm no NV, pode ser explicada pela maior porcentagem de macroporos nessa camada (quando comparada às demais camadas), que proporcionou a drenagem da água.

A água que está disponível às plantas é definida pela área da curva entre as tensões consideradas para capacidade de campo (CC) e ponto de murcha permanente (PMP). Na literatura, existem diferentes considerações quanto à tensão assumida para CC e, como o valor varia com o tipo e manejo do solo, o ideal é que seja determinado no campo. No que se refere à tensão máxima para determinar a água disponível, o PMP é mencionado por muitos autores. Entretanto, deve-se assumir o PMP com cautela, já que sérios prejuízos às plantas e à produtividade podem ocorrer em função do défice e hídrico em tensões menores que $1500 \mathrm{kPa}$ (PMP). Como não foi determinada a capacidade de campo nesse estudo, não foi possível calcular a água disponível às plantas. Entretanto, a curva de retenção em diferentes profundidades foi utilizada para auxiliar no diagnóstico das condições físicas do solo que poder ter influenciado o desenvolvimento radicular.

As variações na curva de retenção ocorridas em função das diferentes profundidades do perfil relacionam-se com as diferenças estruturais dos solos estudados. Conforme mencionado em Brady \& Weil (1999), a estrutura do solo também influencia a relação entre água armazenada e tensão. Solos bem estruturados possuem mais porosidade e maior capacidade de armazenamento de água quando comparados a solos mal estruturados e/ou compactados. A estrutura do solo influencia predominantemente a forma da curva de retenção de água na região em que as tensões estão entre 0 e 100 kPa. Já outros pontos da curva normalmente refletem a influência da textura do solo.

A Tabela 6 traz informações sobre a densidade, resistência à penetração e porosidade, com comparação de médias entre tratamentos e profundidades. No LVA, camadas de solo que apresentaram maiores valores de densidade também apresentaram 
menor porosidade total e menor porcentagem de macroporos. No NV, a profundidade com maior densidade do solo apresentou maior resistência à penetração, menor porosidade total e menor porcentagem de macroporos.

Tabela 6. Média de atributos físicos entre profundidades para os solos LVA e NV

\begin{tabular}{cccccc}
\hline $\begin{array}{c}\text { Profundidade } \\
\mathrm{cm}\end{array}$ & $\begin{array}{c}\text { Ds } \\
\mathrm{g} \mathrm{cm}^{-3}\end{array}$ & $\begin{array}{c}\text { RP } \\
\mathrm{MPa}\end{array}$ & Ptotal & $\begin{array}{c}\text { Macroporos } \\
\%\end{array}$ & Microporos \\
\hline \multicolumn{7}{c}{ Latossolo Vermelho-Amarelo Distrófico psamítico (LVA) } \\
$0-20$ & 1,53 & $1,24 \mathrm{a}$ & 47 & 11 & 36 \\
$20-40$ & 1,58 & $0,44 \mathrm{~b}$ & 44 & 10 & 34 \\
$40-100$ & 1,52 & $0,22 \mathrm{~b}$ & 47 & 14 & 33 \\
$0-20$ & $1,47 \mathrm{~b}$ & $0,91 \mathrm{c}$ & 49 a & 18 a & 31 \\
$20-40$ & 1,77 a & $2,52 \mathrm{a}$ & $44 \mathrm{~b}$ & $9 \mathrm{~b}$ & 35 \\
$40-100$ & $1,49 \mathrm{~b}$ & $1,57 \mathrm{~b}$ & $50 \mathrm{a}$ & $13 \mathrm{ab}$ & 37
\end{tabular}

Ds = densidade do solo; RP = resistência à penetração; Ptotal = porosidade total. Médias de três repetições contidas em colunas e seguidas de mesma letra não diferem entre si pelo teste de Tukey.

Segundo os valores de densidade do solo mencionados por Viehmeyer \& Hendrickson (1949) como restritivos ao crescimento de raízes de várias espécies de plantas, o solo argiloso apresentou densidade desfavorável ao crescimento radicular nas três profundidades estudadas. Já no LVA, a densidade do solo não figurou como restritiva às raízes. Entretanto, Humbert (1974), sem especificar a textura do solo, menciona que densidade de $1,36 \mathrm{~g} \mathrm{~cm}^{-3}$ comprometeu o crescimento de raízes de canade-açúcar.

Fernandes et al. (1983) mencionam que densidade do solo superior a $1,45 \mathrm{~g} \mathrm{~cm}^{-3}$ fez com que as raízes de cana-de-açúcar não se desenvolvessem plenamente, prejudicando a parte aérea da planta por não suprir satisfatoriamente as necessidades nutricionais. 
Vasconcelos (2002) verificou que houve desenvolvimento de raízes de cultivares de cana-de-açúcar em Latossolo Vermelho textura média mediante aumento na densidade do solo que atingiu o valor de $1,64 \mathrm{~g} \mathrm{~cm}^{-3}$. Faroni (2005) avaliou o sistema radicular de soqueiras de cana-de-açúcar e encontrou valores de densidade entre 1,47 e $1,59 \mathrm{~g} \mathrm{~cm}^{-3}$ para um Latossolo Vermelho textura média-arenosa. O mesmo autor também verificou valores mais elevados na profundidade de $20-40 \mathrm{~cm}$.

A relação entre resistência à penetração e crescimento radicular foi estudada por vários autores (Bradford, 1986; Boone et al., 1986; Rosolem et al., 2002) e os valores considerados restritivos ao crescimento radicular variaram de 1,34 MPa a 3 MPa para diferentes espécies. Pfeffer (1983) ${ }^{1}$, citado por Bennie (1996), fez as primeiras medidas diretas da máxima pressão de crescimento radicular, encontrando valores entre 0,7 $\mathrm{MPa}$ a 2,5 MPa para diferentes espécies.

Os atributos físicos do solo como porosidade, densidade, textura, resistência à penetração, presença de bioporos, tamanho de agregados e macroestrutura, bem como o conteúdo de água, devem ser avaliados em conjunto para que se possa considerar os efeitos da física do solo no crescimento radicular. Além disso, esses atributos devem ser associados ao fator clima e às práticas de manejo adotadas.

Valores de densidade do solo podem ser menos conclusivos quanto ao crescimento radicular pois, o umidecimento do solo é um meio bastante efetivo para reduzir o impedimento mecânico (Bennie, 1996). Se a resistência à penetração do solo úmido ou molhado é maior que $2 \mathrm{MPa}$, procedimento mais efetivo deve ser adotado para minimizar o impedimento mecânico (Bennie, 1996). Se o processo de umidecimento e secagem é acompanhado por compressão e expansão, surgem fissuras no perfil do solo. Tais fissuras constituirão o principal local para crescimento radicular e dificilmente serão detectadas por testes de penetrabilidade (Bennie, 1996).

${ }^{1}$ PFEFFER, W. Druck und Arbeitsleistung durch wachsende Pflanzen. Abhandlungen der Sächsischen Akademie der Wissenschaften zu Leipzig. v. 33, p. 235-474, 1893. 


\subsection{Avaliação da distribuição do sistema radicular}

Constatou-se diferença no comprimento de raízes entre os lados esquerdo e direito das linhas de cana-de-açúcar, tanto no LVA quanto no NV. Assim, os dois lados foram analisados separadamente para avaliar a distribuição radicular horizontal (em três distâncias laterais a partir das linhas de cana) e vertical (em diferentes profundidades no perfil do solo).

As Figuras 10 e 11 ilustram a distribuição radicular no LVA e NV, respectivamente. A distribuição vertical é ilustrada pelas Figuras 12 e 13 para os mesmos solos.

Nos primeiros $18 \mathrm{~cm}$ de profundidade do LVA, o comprimento radicular foi maior do lado direito das linhas de cana. O cultivar RB83 5486 apresentou maior comprimento de raízes que RB83 5089 nas três distâncias horizontais. O maior comprimento de raízes ocorreu na distância horizontal 0-18 cm para os dois cultivares (Figura 10).

Na profundidade 18-36 cm, o cultivar RB83 5486 teve maior comprimento radicular que RB83 5089 principalmente do lado direito das touceiras de cana. Do lado esquerdo houve diferença entre cultivares somente na distância horizontal $36-54 \mathrm{~cm}$. Maior comprimento radicular ocorreu na distância horizontal 0-18 cm para o RB83 5486, enquanto que o RB83 5089 apresentou distribuição horizontal homogênea nessa profundidade (Figura 10).

A partir dos $36 \mathrm{~cm}$ até $54 \mathrm{~cm}$ de profundidade, RB83 5486 apresentou maior comprimento radicular que RB83 5089 nas três distâncias horizontais do lado direito e somente na distância horizontal 0-18 cm do lado esquerdo das linhas de cana (Figura 10).

Diferença entre RB83 5486 e RB83 5089 foi encontrada para comprimento radicular na profundidade 54-72 cm no LVA, principalmente do lado direito das linhas de cana. Na distribuição horizontal, RB83 5486 apresentou maior diferença, com maior valor de comprimento radicular na distância 18-36 cm da linha (Figura 10). 

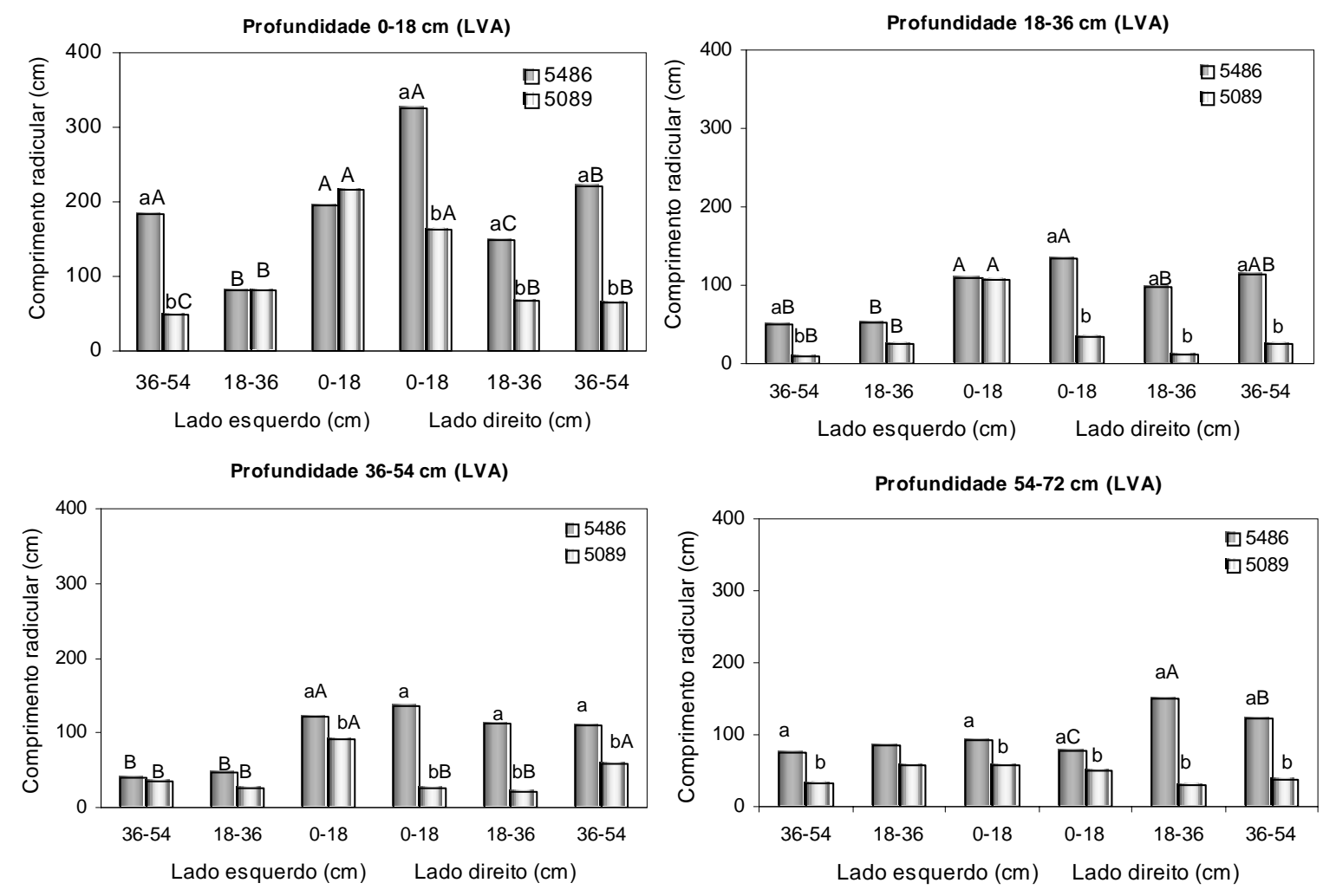

Figura 10 - Comprimento radicular nos lados esquerdo e direito das linhas de cana-de-açúcar em quatro profundidades no LVA. Letras minúsculas comparam cultivares dentro de cada distância horizontal. Letras maiúsculas comparam cada cultivar em relação às três distâncias horizontais 

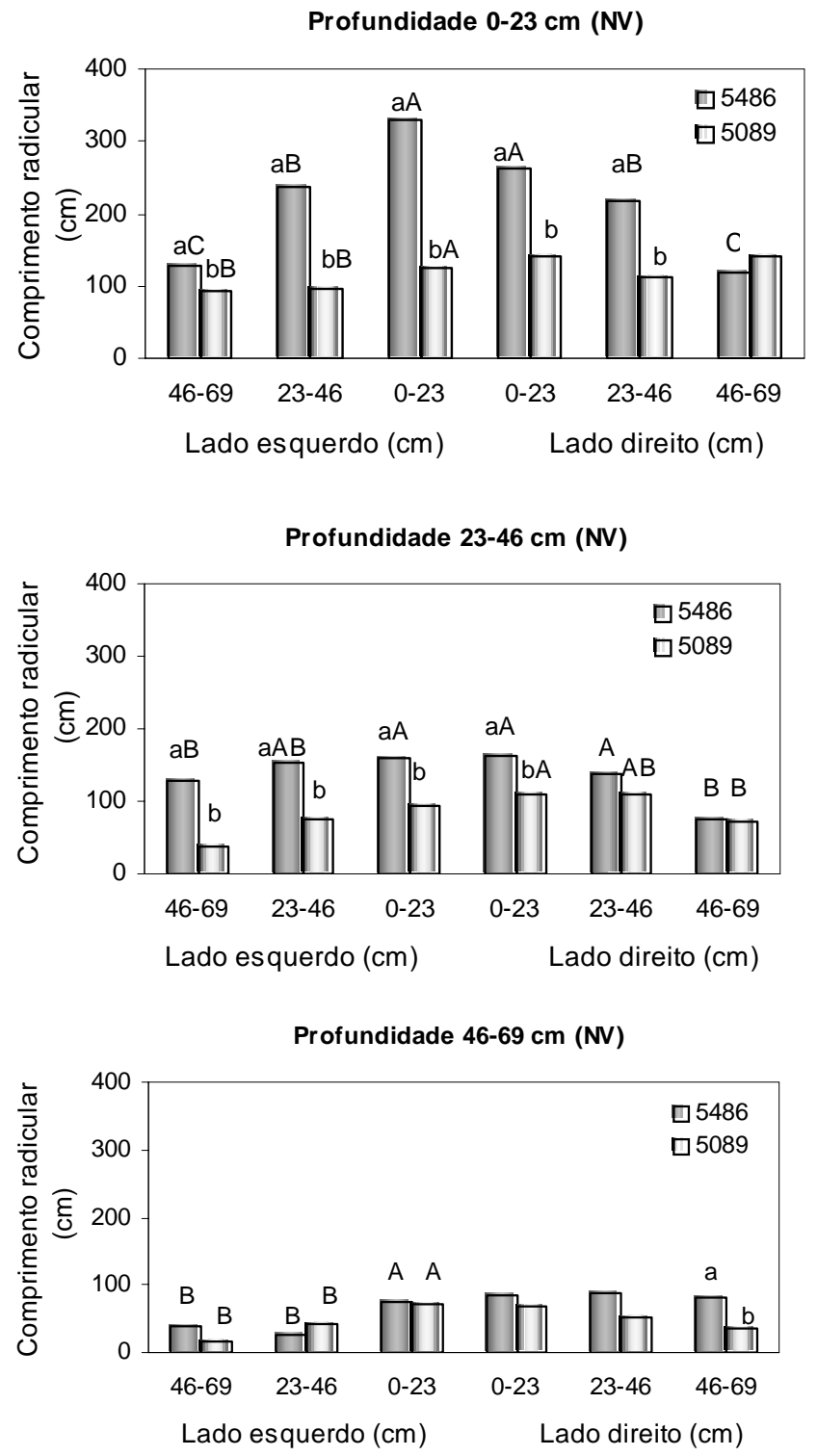

Figura 11 - Comprimento radicular nos lados esquerdo e direito das linhas de cana-de-açúcar em três profundidades no NV. Letras minúsculas comparam cultivares dentro de cada distância horizontal. Letras maiúsculas comparam cada cultivar em relação às três distâncias horizontais 
Quanto à distribuição horizontal no NV, nos primeiros $23 \mathrm{~cm}$ de profundidade foi constatado maior comprimento radicular para o cultivar RB83 5486, nos dois lados das linhas de cana. O maior comprimento de raízes foi encontrado na distância 0-23 cm das linhas, principalmente para o RB83 5486. Já o cultivar RB83 5089 apresentou distribuição horizontal homogênea (Figura 11).

A partir dos $23 \mathrm{~cm}$ de profundidade, a diferença entre cultivares foi verificada principalmente do lado esquerdo das linhas. Maiores valores de comprimento radicular ocorreram nas distâncias de 0-23 cm e 23-46 cm das linhas de cana para os dois cultivares (Figura 11).

$\mathrm{Na}$ profundidade de 46-69 $\mathrm{cm}$ somente houve diferença entre cultivares na distância 46-69 cm, do lado direito das linhas de cana (Figura 11).

Faroni (2005) encontrou 65\% da quantidade de raízes de cana-de-açúcar na projeção das linhas e somente 18\% na distância de 14 a 42 cm. Alvarez (2000) também observou maior quantidade de raízes bem próxima às linhas de cana.

A distribuição horizontal de raízes de cana-de-açúcar pode ser influenciada pela posição em que é aplicada a adubação de soqueiras e pelo efeito do tráfego de máquinas e implementos. O acúmulo de nutrientes em determinado local no solo pode proporcionar maior crescimento de raízes devido à maior disponibilidade de nutrientes (Dunbabin et al., 2001). O efeito do tráfego de máquinas e implementos pode ocasionar maior compactação em locais específicos que apresentarão condições desfavoráveis ao desenvolvimento radicular. Como o tráfego ocorre principalmente nas entrelinhas, maior compactação e menor quantidade de raízes é esperada nesse local. Entretanto, trabalhos mostraram efeitos do tráfego de máquinas nas linhas de cana (Braunack \& Peatey, 1999; Vasconcelos, 2002; Faroni, 2005). 

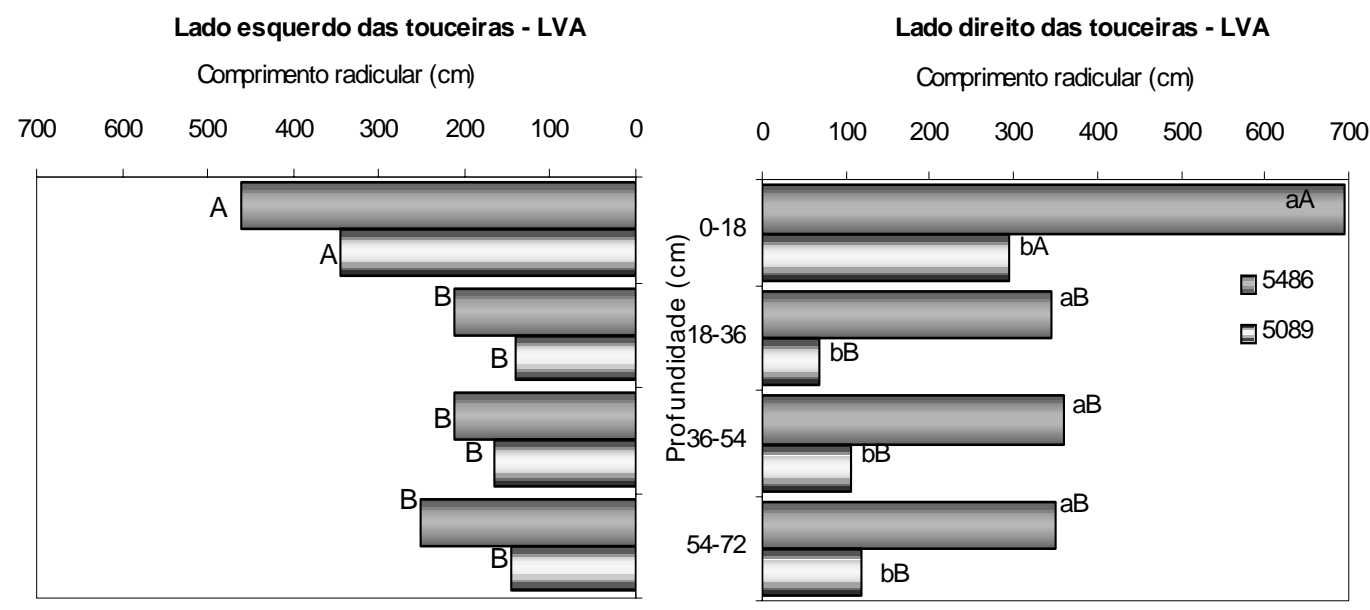

Figura 12 - Comprimento radicular de soqueiras de cana-de-açúcar em profundidade no perfil do LVA
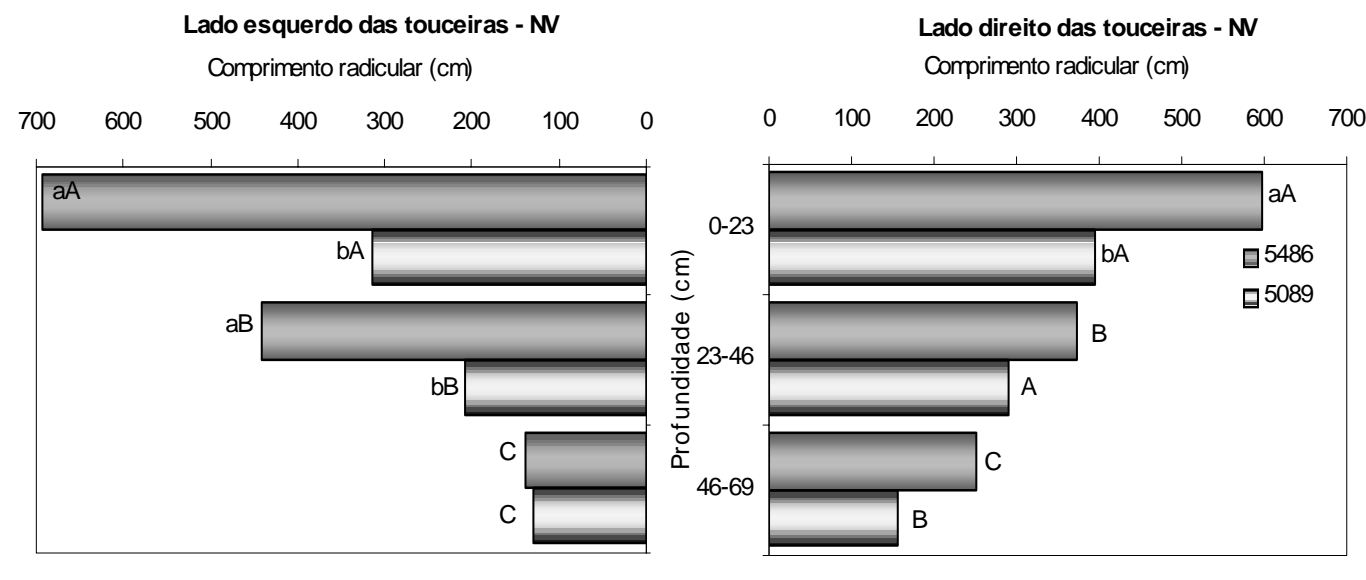

Figura 13 - Comprimento radicular de soqueiras de cana-de-açúcar em profundidade no perfil do NV

Na avaliação da distribuição radicular vertical no LVA, o cultivar RB83 5486 diferiu do RB83 5089 no lado direito das linhas de cana-de-açúcar, apresentando maior comprimento radicular em todas profundidades. Os primeiros $18 \mathrm{~cm}$ de profundidade apresentaram maior comprimento de raízes. A redução no comprimento radicular foi acentuada quando se passou da profundidade de 0-18 cm para 18-36 cm. Já nas maiores profundidades, a redução no comprimento radicular não foi acentuada (Figura 12). 
No NV, o cultivar RB83 5486 somente diferiu do RB83 5089 nos primeiros 23 cm de profundidade do lado direito. Do lado esquerdo, os cultivares diferiram nas profundidades $0-23 \mathrm{~cm}$ e $23-46 \mathrm{~cm}$. Nas camadas mais profundas, a redução no comprimento radicular foi mais acentuada, exibindo menores valores em relação àqueles encontrados no LVA, principalmente para o cultivar RB83 5486.

No LVA, o maior comprimento radicular do RB83 5486 em relação ao RB83 5089, associado à melhor distribuição de raízes em profundidade, constituiu característica favorável do cultivar RB83 5486. Maior quantidade de raízes em profundidade, além de favorecer a absorção de água em épocas de défice hídrico, permite a absorção de nitrogênio que tenha sido deslocado para camadas mais profundas (Gregory et al., 1979).

Outros estudos referentes à distribuição vertical de raízes de cana-de-açúcar no perfil do solo indicaram cerca de $60 \%$ a $70 \%$ da quantidade de raízes concentrando-se nos primeiros $20 \mathrm{~cm}$ de profundidade (Lee, 1926; Inforzato \& Alvarez, 1957; Alvarez, 2000; Faroni, 2005).

Vasconcelos (2002) menciona que a quantidade e a distribuição de raízes de cana-de-açúcar mudam ao longo do tempo devido às alterações naturais no clima e no solo e devido à ação antrópica. O mesmo autor encontrou diferença entre cultivares quanto à distribuição de raízes em profundidade no perfil do solo, afirmando que a maior quantidade de raízes em camadas mais profundas atribui-se à tolerância ao alumínio existente em determinados cultivares. 


\subsection{Avaliação da renovação do sistema radicular a partir da brotação de soqueiras}

\subsubsection{Diâmetro médio radicular}

Na análise da morfologia externa, as raízes de cana-de-açúcar foram classificadas em quatro classes de diâmetro: 0-0,2 mm; 0,2-0,4 mm; 0,4-0,8 mm e 0,8-2,0 mm. O comprimento radicular foi medido em cada classe de diâmetro e o maior comprimento de raízes foi encontrado na classe 0,2-0,4 mm para os dois cultivares em diferentes profundidades dos dois solos e em diferentes épocas de amostragem.

O diâmetro médio radicular variou, em profundidade, de 0,70 a 0,83 mm no LVA e de 0,59 a 0,73 mm no NV (Figuras 14 e 15). A classe de diâmetro para raízes de canade-açúcar encontrada por Ball-Coelho et al. (1992) variou entre 0,05 e 1,1 mm. Porém, o diâmetro médio de raízes encontrado pelos mesmos autores foi menor $(0,20$ a 0,26 mm) em relação ao encontrado no presente trabalho.

Embora tenha sido constatada maior compactação no NV (Tabela 6), as raízes apresentaram-se mais espessas no LVA. Uma possibilidade para explicar o maior diâmetro médio de raízes neste solo, seria a maior ocorrência de nematóides. No presente estudo não foi realizado levantamento da incidência de nematóides nas áreas experimentais. Porém, sabe-se que diversos nematóides podem causar danos na cultura da cana-de-açúcar. Algumas espécies ocorrem preferencialmente em solo arenoso, outras em solo argiloso, sendo que outras espécies proliferam-se em ambos tipos de solo. Os sintomas de danos nas raízes também são variáveis (Spaull \& Cadet, 1993).

Tanto no LVA quanto no NV houve aumento do diâmetro radicular com a profundidade. No LVA, houve aumento no diâmetro médio de raízes a partir dos $20 \mathrm{~cm}$ de profundidade do solo, para os dois cultivares. No NV, o aumento no diâmetro médio radicular foi mais evidente para o cultivar RB83 5089 na profundidade de $30 \mathrm{~cm}$. O engrossamento radicular é uma característica para raízes que crescem em solos compactados (Bennie, 1991).

Whitely \& Dexter (1984) mencionam que plantas com grande quantidade de

raízes finas apresentam melhores condições de crescimento em solos com camadas compactadas. No presente trabalho, condições satisfatórias ao crescimento radicular 
foram encontradas na camada superficial do NV. Como houve aumento na compactação do solo nas camadas mais profundas, a superfície menos compactada apresentou crescimento radicular mais intenso. Mapfumo et al. (1998) observaram que, com o aumento da compactação em subsuperfície, a porcentagem total de biomassa radicular aumentou na camada superficial não compactada em solos de textura média e argilosa.

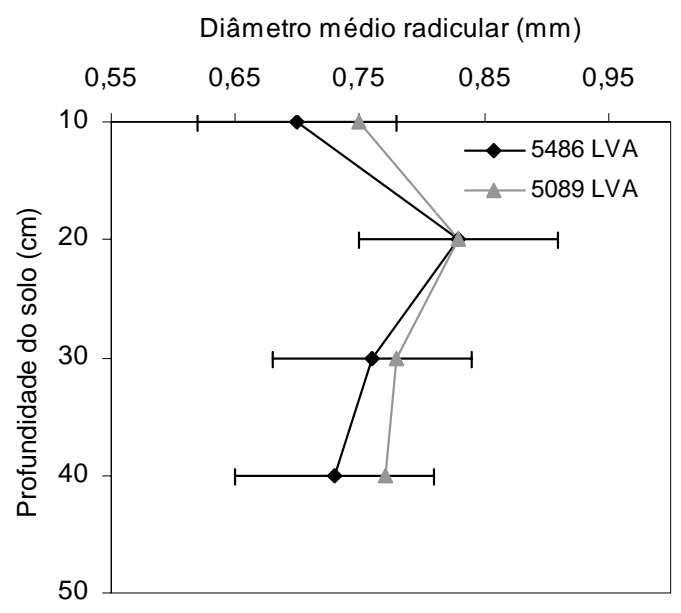

Figura 14 - Diâmetro médio radicular de dois cultivares de cana-de-açúcar (RB83 5486 e RB83 5089) no LVA

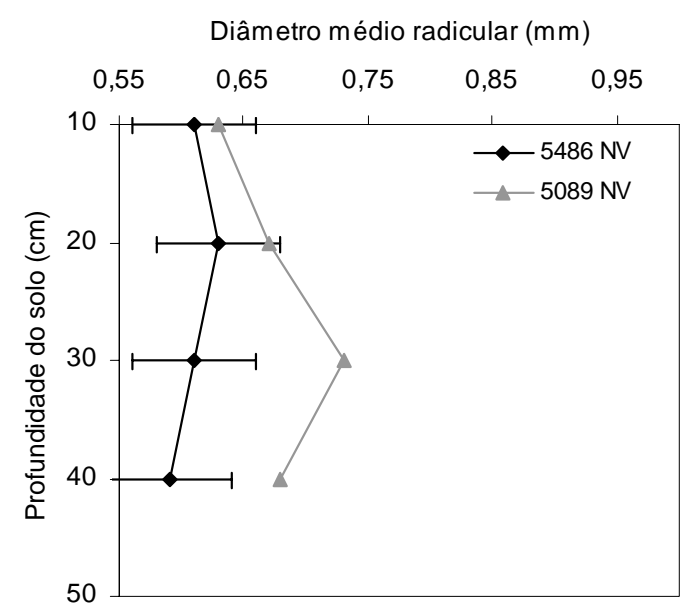

Figura 15 - Diâmetro médio radicular de dois cultivares de cana-de-açúcar (RB83 5486 e RB83 5089) no NV

\subsubsection{Comprimento e densidade radicular ao longo do tempo}

A dinâmica de crescimento foi estudada para raízes amostradas em diferentes épocas a partir do início da brotação da quarta soca (10, 40, 70 e 160 dias a partir do início da brotação).

Na primeira época de amostragem no LVA, o cultivar RB83 5486 apresentou maior comprimento radicular que RB83 5089 na camada de 0 a $10 \mathrm{~cm}$. No mesmo solo houve redução no comprimento radicular a partir da segunda amostragem, principalmente nos primeiros $10 \mathrm{~cm}$ de profundidade. Na segunda época de amostragem o comprimento radicular para RB83 5486 também foi maior quando comparado ao RB83 5089 (Figura 16).

Na terceira época de amostragem, o comprimento radicular na profundidade 0-10 cm foi menor para RB83 5486 e maior para RB83 5089 (Figura 16). Nos resultados 
referentes à última época de amostragem, houve aumento no comprimento radicular em todas profundidades do solo. Provavelmente isso ocorreu devido ao aumento na precipitação verificado nesse período (Figura 18) que, além de estimular o desenvolvimento da planta, também tornou o solo mais friável, reduzindo a resistência do mesmo ao desenvolvimento radicular. Na profundidade 0-10 cm, o cultivar RB83 5089 apresentou maior comprimento de raízes quando comparado ao RB83 5486 (Figura 16).

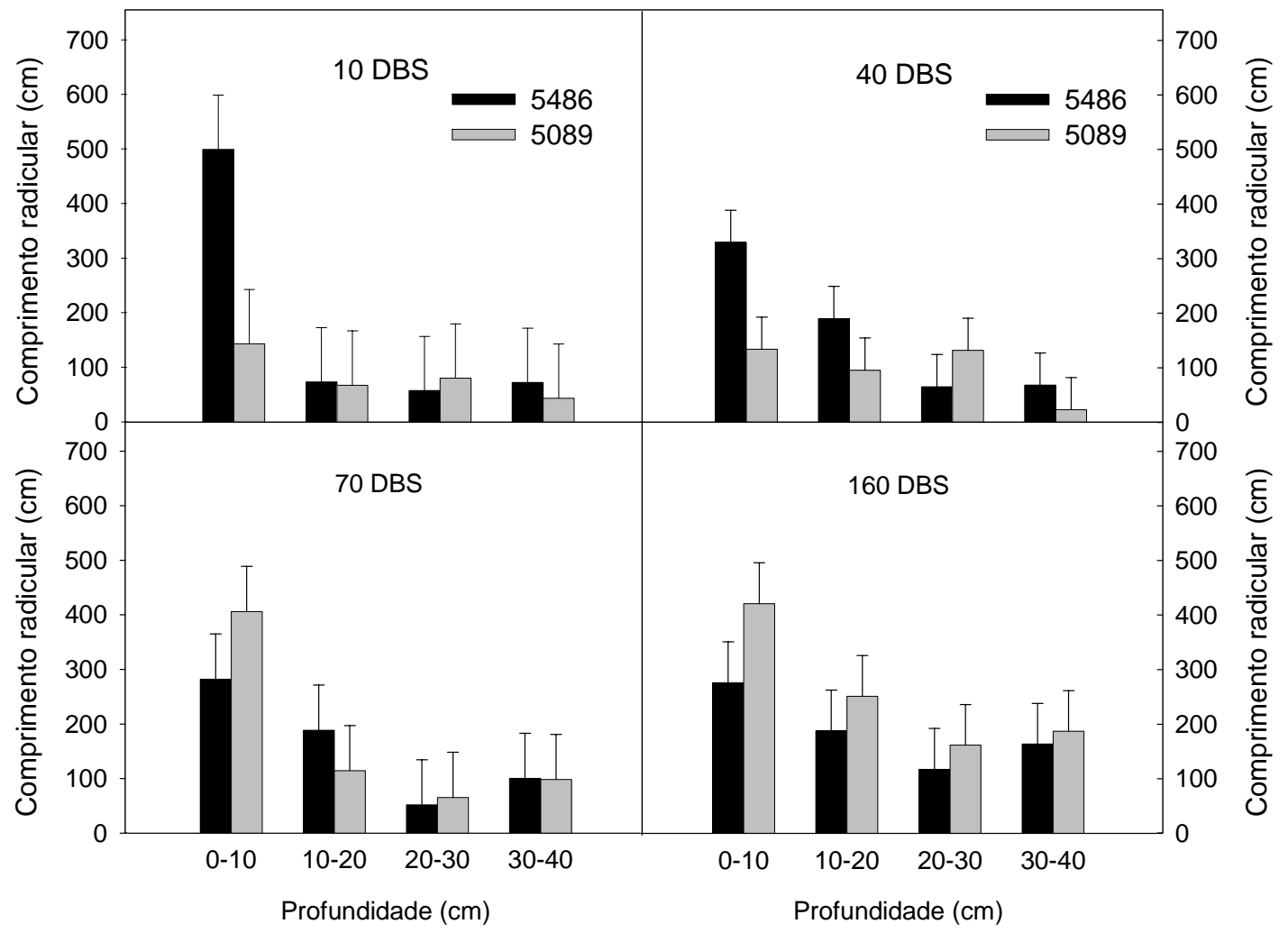

Figura 16 - Comprimento radicular dos cultivares RB83 5486 e RB83 5089 plantados no LVA em quatro épocas a partir da brotação das soqueiras. DBS: Dias após início da brotação das soqueiras. Barras de erro = DMS $(0,05)$ 


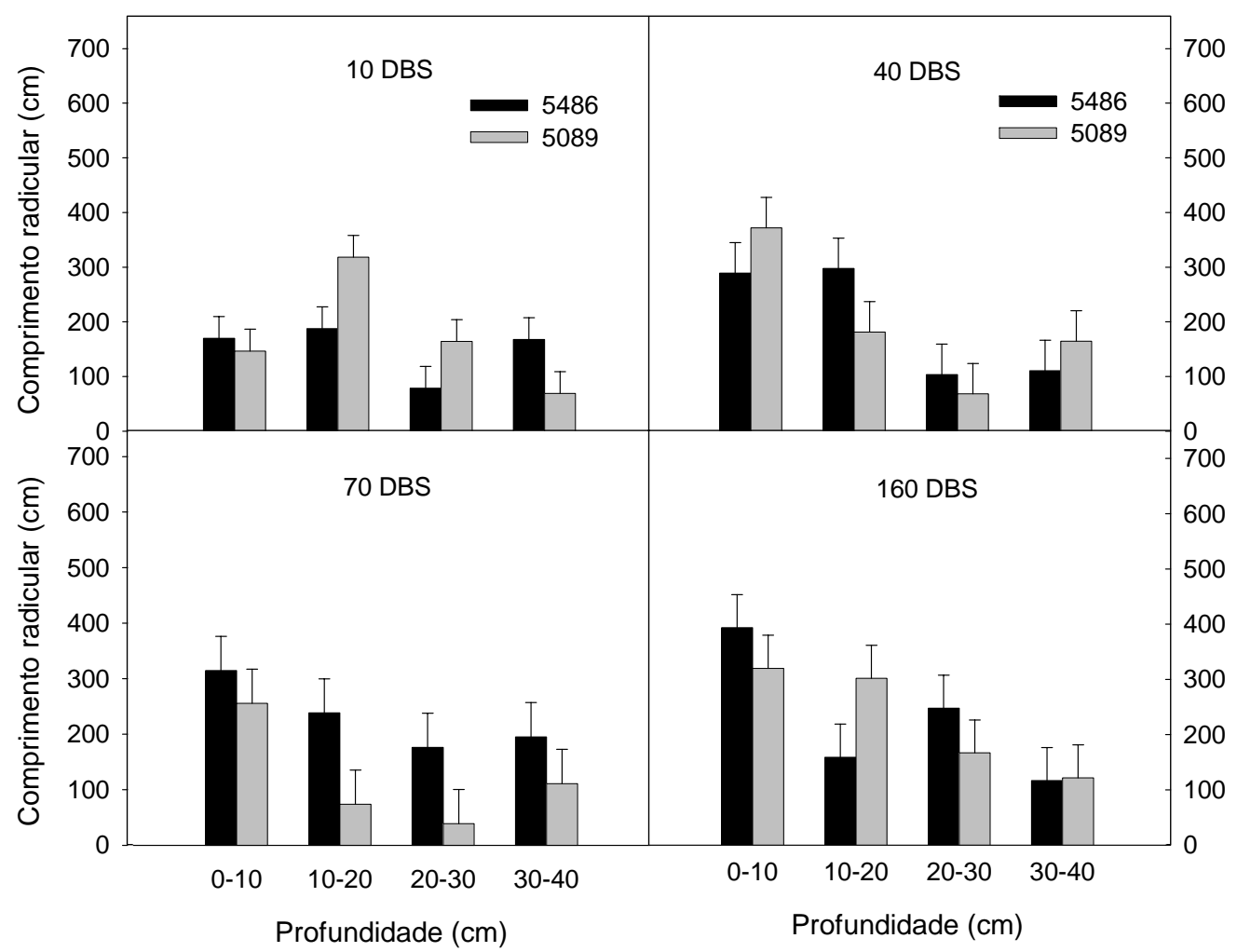

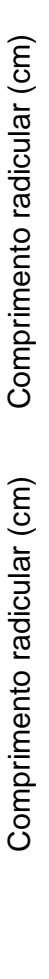

Figura 17 - Comprimento radicular dos cultivares RB83 5486 e RB83 5089 plantados no NV em quatro épocas a partir da brotação das soqueiras. DBS: Dias após início da brotação das soqueiras. Barras de erro = DMS $(0,05)$

No NV contatou-se que, durante a primeira época de amostragem, o cultivar RB83 5089 apresentou maior comprimento radicular nas profundidades de 10-20 e 20$30 \mathrm{~cm}$, contrastando com valores encontrados na profundidade $30-40 \mathrm{~cm}$ na qual o comprimento radicular foi maior para RB83 5486 (Figura 17).

Na segunda época de amostragem, o comprimento radicular foi maior para RB83 5089 nos primeiros $10 \mathrm{~cm}$ de profundidade. Porém, na profundidade 10-20 cm, maiores valores foram registrados para RB83 5486.

A análise dos resultados da terceira época de amostragem indicou que o cultivar RB83 5486 apresentou maior comprimento de raízes que RB83 5089 em todas profundidades estudadas. Na quarta amostragem foi encontrado maior comprimento para RB83 5486 nas profundidades 0-10 e 20-30 cm. Já na profundidade 10-20 cm, o cultivar RB83 5089 apresentou maior comprimento de raízes que RB83 5486 (Figura 17). 


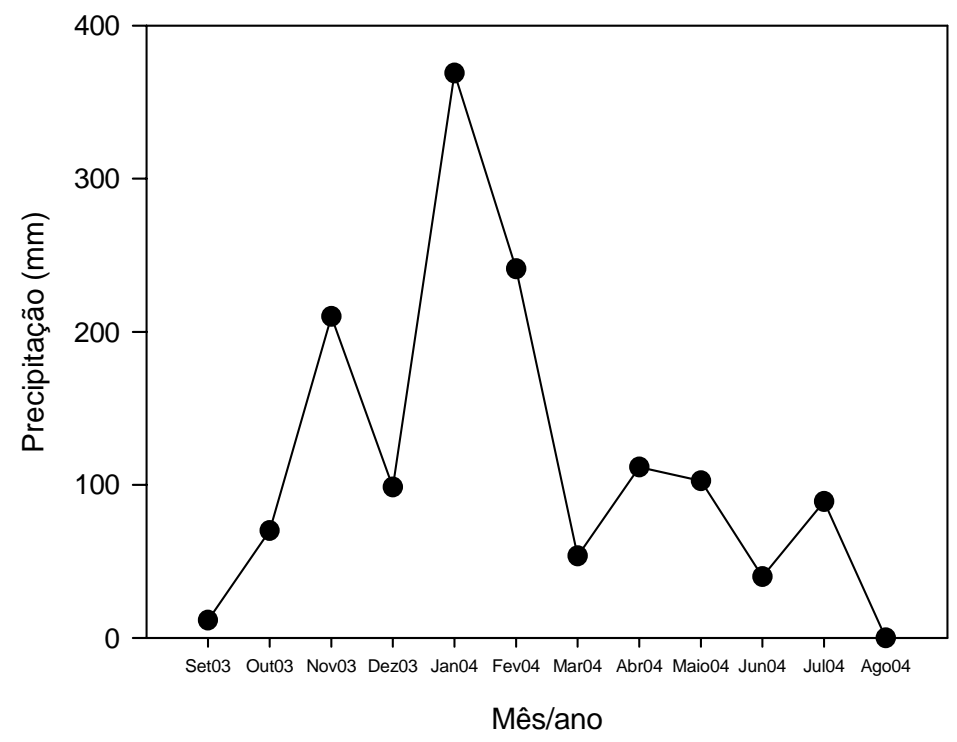

Figura 18 - Precipitação no período a partir da brotação da quinta soca

Considerando as demais classes de diâmetro que foram determinadas, no LVA as raízes muito finas $(0-0,2 \mathrm{~mm})$ foram mais abundantes para o cultivar RB83 5486 na camada superficial $(0-10 \mathrm{~cm})$ por ocasião da primeira amostragem. Amostras da segunda e terceira coletas indicaram maior quantidade de raízes finas para o RB83 5089 nas profundidades de 20-30 e 30-40 cm (Tabela 7).

Na classe de diâmetro 0,4-0,8 mm, o cultivar RB83 5486 apresentou mais raízes que RB83 5089 na camada superficial do LVA, tanto na segunda quanto na terceira época de amostragem. Na última coleta, RB83 5089 superou RB83 5486 nessa classe de diâmetro na profundidade 20-30 cm (Tabela 7)

Para a classe de diâmetro representativa de raízes espessas $(0,8-2,0 \mathrm{~mm})$ foi registrado maior comprimento radicular para RB83 5486 na profundidade 0-10 cm na primeira amostragem, sendo que, na última coleta, RB83 5089 superou RB83 5486. Padrão semelhante foi verificado nas profundidades 20-30 e 30-40 cm (Tabela 7)

No que se refere às diferenças entre cultivares no decorrer do tempo, para todas classes de diâmetro no LVA, principalmente na camada superficial, observou-se redução 
no comprimento radicular do RB83 5486 da primeira para a última amostragem, enquanto que os valores aumentaram para RB83 5089 (Tabela 7) 
Tabela 7. Comprimento de raízes (cm) em três classes de diâmetro de dois cultivares de cana-de-açúcar (RB83 5486 e RB83 5089) no perfil do LVA aos 10, 40, 70 e 160 dias após início da brotação das soqueiras (DBS)

\begin{tabular}{|c|c|c|c|c|c|c|c|c|}
\hline \multirow[t]{3}{*}{ Época (DBS) } & \multicolumn{8}{|c|}{ Profundidade $(\mathrm{cm})$} \\
\hline & \multicolumn{2}{|c|}{$0-10$} & \multicolumn{2}{|c|}{$10-20$} & \multicolumn{2}{|c|}{$20-30$} & \multicolumn{2}{|c|}{$30-40$} \\
\hline & 5486 & 5089 & 5486 & 5089 & 5486 & 5089 & 5486 & 5089 \\
\hline \multicolumn{9}{|c|}{$\mathrm{cm}$} \\
\hline \multicolumn{9}{|c|}{ Classe de diâmetro 0-0,2 mm } \\
\hline 10 & $90,8 \mathrm{aA}$ & $21,6 \mathrm{bB}$ & $12,6 \mathrm{C}$ & $9,1 \mathrm{~B}$ & $8,9 \mathrm{~B}$ & $5,7 \mathrm{D}$ & $10,7 \mathrm{~B}$ & $5,7 \mathrm{C}$ \\
\hline 40 & $45,0 \mathrm{aC}$ & $31,2 \mathrm{bB}$ & $29,3 \mathrm{~B}$ & 19,6B & $16,4 \mathrm{bA}$ & $22,7 \mathrm{aB}$ & $8,5 \mathrm{~B}$ & $4,4 \mathrm{C}$ \\
\hline 70 & $70,8 \mathrm{aB}$ & $56,0 \mathrm{bA}$ & $29,7 \mathrm{~B}$ & 17,7B & $7,6 \mathrm{~B}$ & $10,5 \mathrm{C}$ & 8,9bB & $14,5 \mathrm{aB}$ \\
\hline 160 & 44,7C & $57,6 \mathrm{~A}$ & $62,2 \mathrm{aA}$ & $36,8 \mathrm{bA}$ & $16,1 \mathrm{bA}$ & $30,6 \mathrm{aA}$ & $26,2 \mathrm{~A}$ & $22,4 \mathrm{~A}$ \\
\hline DMS & \multicolumn{2}{|c|}{13,7} & \multicolumn{2}{|c|}{13,3} & \multicolumn{2}{|c|}{4,2} & \multicolumn{2}{|c|}{5,5} \\
\hline CV (\%) & \multicolumn{2}{|c|}{16,8} & \multicolumn{2}{|c|}{30,3} & \multicolumn{2}{|c|}{18,2} & \multicolumn{2}{|c|}{27,8} \\
\hline \multicolumn{9}{|c|}{ Classe de diâmetro 0,4-0,8 mm } \\
\hline 10 & $65,1 \mathrm{aA}$ & $25,8 \mathrm{bB}$ & $9,0 \mathrm{~B}$ & $7,5 \mathrm{BC}$ & $10,4 \mathrm{AB}$ & 7,9D & 9,7B & 7,9B \\
\hline 40 & $51,9 \mathrm{aA}$ & $13,9 \mathrm{bB}$ & $22,2 \mathrm{~A}$ & $18,2 B$ & $14,8 \mathrm{bA}$ & $22,9 a B$ & $14,2 \mathrm{~B}$ & $7,0 \mathrm{~B}$ \\
\hline 70 & $42,2 \mathrm{AB}$ & $43,3 \mathrm{~A}$ & $30,9 \mathrm{~A}$ & $25,4 \mathrm{AB}$ & $9,8 \mathrm{bB}$ & $14,4 \mathrm{aC}$ & $13,8 \mathrm{~B}$ & $18,7 \mathrm{~A}$ \\
\hline 160 & 34,3bB & $56,8 \mathrm{aA}$ & $28,7 \mathrm{~A}$ & $32,9 \mathrm{~A}$ & $6,8 \mathrm{bB}$ & $30,4 a A$ & $27,1 \mathrm{~A}$ & $25,3 \mathrm{~A}$ \\
\hline DMS & \multicolumn{2}{|c|}{13,8} & \multicolumn{2}{|c|}{12,6} & \multicolumn{2}{|c|}{4,8} & \multicolumn{2}{|c|}{7,3} \\
\hline CV (\%) & \multicolumn{2}{|c|}{18,4} & \multicolumn{2}{|c|}{22,7} & \multicolumn{2}{|c|}{20,9} & \multicolumn{2}{|c|}{26,5} \\
\hline \multicolumn{9}{|c|}{ Classe de diâmetro 0,8-2,0 mm } \\
\hline 10 & $108,2 \mathrm{aA}$ & 38,6bB & $18,5 \mathrm{~B}$ & 25,7B & $32,7 \mathrm{aA}$ & $17,7 \mathrm{bB}$ & $50,6 \mathrm{aA}$ & $17,7 \mathrm{bB}$ \\
\hline 40 & $48,2 \mathrm{~B}$ & 48,1B & 42,9A & $31,0 \mathrm{~B}$ & $16,2 \mathrm{~B}$ & $27,3 \mathrm{~B}$ & $22,2 \mathrm{aC}$ & $11,1 \mathrm{bB}$ \\
\hline 70 & $55,4 \mathrm{~B}$ & $64,1 \mathrm{~B}$ & $42,4 \mathrm{~A}$ & 52,7A & $32,5 \mathrm{~A}$ & $24,6 \mathrm{~B}$ & $21,6 \mathrm{bC}$ & $32,0 \mathrm{aA}$ \\
\hline 160 & 47,3bB & $91,2 \mathrm{aA}$ & $46,1 \mathrm{~A}$ & $61,0 \mathrm{~A}$ & $11,7 \mathrm{bB}$ & $58,3 a A$ & $34,6 \mathrm{~B}$ & $29,1 \mathrm{~A}$ \\
\hline DMS & \multicolumn{2}{|c|}{20,97} & \multicolumn{2}{|c|}{15,7} & \multicolumn{2}{|c|}{13,05} & \multicolumn{2}{|c|}{9,7} \\
\hline CV (\%) & \multicolumn{2}{|c|}{16,7} & \multicolumn{2}{|c|}{22,8} & & 6,8 & 17 & 7,6 \\
\hline
\end{tabular}


No NV, a determinação das demais classes de diâmetro durante a primeira coleta indicou não haver diferença entre cultivares para raízes muito finas $(0-0,2 \mathrm{~mm})$ nos primeiros $20 \mathrm{~cm}$ de profundidade. Já na profundidade 20-30 cm, o cultivar RB83 5089 apresentou maior comprimento radicular que RB83 5486, com inversão da situação na profundidade 30-40 cm. Por ocasião da segunda coleta, RB83 5089 apresentou maior comprimento radicular que RB83 5486 nas profundidades 0-10 e 30-40 cm, enquanto que RB83 5486 teve maiores valores nas profundidades 10-20 e 20-30 cm (Tabela 8).

Na observação do comprimento de raízes muito finas por ocasião da terceira coleta, constatou-se que o cultivar RB83 5486 apresentou maiores valores que RB83 5089 em todas profundidades avaliadas. Já na última amostragem, RB83 5089 apresentou maior comprimento de raízes finas que o RB83 5486 na profundidade 10-20 cm e menores valores na profundidade $20-30 \mathrm{~cm}$ (Tabela 8).

Considerando a classe de diâmetro 0,4-0,8 mm por ocasião da primeira amostragem, o cultivar RB83 5486 apresentou maior comprimento de raízes nas profundidades $0-10$ e 30-40 cm, enquanto que na profundidade $10-20 \mathrm{~cm}$ o maior comprimento radicular foi verificado para RB83 5089 (Tabela 8).

Na primeira coleta, raízes mais espessas $(0,8-2,0 \mathrm{~mm})$ foram encontradas para o cultivar RB83 5089 nas profundidades $10-20$ e $20-30 \mathrm{~cm}$. Na profundidade 30-40 cm o cultivar RB83 5486 se sobressaiu em relação ao RB83 5089. Na terceira e na última amostragem, somente houve diferença para as profundidades de 0-10 e 30-40 cm, respectivamente, com maior comprimento radicular para RB83 5089 (Tabela 8).

Quanto às diferenças verificadas ao longo do tempo, no NV houve menor evidência de aumento no comprimento radicular com o passar do tempo, principalmente para raízes muito finas. Em determinadas situações, mesmo sem constatar padrão específico considerando cultivares ou profundidade do solo, o comprimento radicular foi maior nas amostragens finais. Entretanto, também foi verificada redução no comprimento de raízes nas coletas intermediárias (Tabela 8). 
Tabela 8. Comprimento de raízes ( $\mathrm{cm}$ ) em três classes de diâmetro de dois cultivares de cana-de-açúcar (RB83 5486 e RB83 5089) no perfil do NV aos 10, 40, 70 e 160 dias após início da brotação das soqueiras (DBS)

\begin{tabular}{|c|c|c|c|c|c|c|c|c|}
\hline \multirow[t]{3}{*}{ Época (DBS) } & \multicolumn{8}{|c|}{ Profundidade $(\mathrm{cm})$} \\
\hline & \multicolumn{2}{|c|}{$0-10$} & \multicolumn{2}{|c|}{$10-20$} & \multicolumn{2}{|c|}{$20-30$} & \multicolumn{2}{|c|}{$30-40$} \\
\hline & 5486 & 5089 & 5486 & 5089 & 5486 & 5089 & 5486 & 5089 \\
\hline \multicolumn{9}{|c|}{$\mathrm{cm}$} \\
\hline \multicolumn{9}{|c|}{ Classe de diâmetro 0-0,2 mm } \\
\hline 10 & $27,1 \mathrm{BC}$ & $22,9 \mathrm{BC}$ & $34,4 \mathrm{AB}$ & 39,8A & $11,2 \mathrm{bD}$ & 20,3aA & $24,6 \mathrm{aB}$ & $12,3 \mathrm{bC}$ \\
\hline 40 & $43,4 \mathrm{bB}$ & $91,4 \mathrm{aA}$ & $48,1 \mathrm{aA}$ & $33,3 \mathrm{bA}$ & $21,6 \mathrm{aC}$ & $9,0 \mathrm{bB}$ & $16,8 \mathrm{bC}$ & $27,7 \mathrm{aA}$ \\
\hline 70 & $67,3 \mathrm{aA}$ & $36,6 \mathrm{bBC}$ & $38,4 \mathrm{aAB}$ & $10,4 \mathrm{bB}$ & $28,7 \mathrm{aB}$ & $5,7 \mathrm{bB}$ & $42,6 \mathrm{aA}$ & $18,9 \mathrm{bB}$ \\
\hline 160 & $57,8 \mathrm{AB}$ & $47,1 \mathrm{~B}$ & $29,6 \mathrm{bB}$ & $45,2 \mathrm{aA}$ & 35,3aA & $16,2 \mathrm{bA}$ & $16,4 \mathrm{C}$ & $16,6 \mathrm{BC}$ \\
\hline DMS & \multicolumn{2}{|c|}{19,2} & \multicolumn{2}{|c|}{14,0} & \multicolumn{2}{|c|}{5,5} & \multicolumn{2}{|c|}{5,9} \\
\hline CV (\%) & \multicolumn{2}{|c|}{24,4} & \multicolumn{2}{|c|}{25,9} & \multicolumn{2}{|c|}{16,7} & \multicolumn{2}{|c|}{14,2} \\
\hline \multicolumn{9}{|c|}{ Classe de diâmetro 0,4-0,8 mm } \\
\hline 10 & $32,3 \mathrm{aA}$ & $13,5 b B$ & 29,3bA & 37,7aA & $7,8 \mathrm{bB}$ & $22,0 \mathrm{aA}$ & 19,1aAB & $10,6 \mathrm{bB}$ \\
\hline 40 & $30,0 \mathrm{~A}$ & $37,8 \mathrm{~A}$ & $21,0 \mathrm{bB}$ & $29,0 \mathrm{aB}$ & $9,4 \mathrm{~B}$ & $10,3 \mathrm{~B}$ & $8,2 \mathrm{bBC}$ & 22,3aA \\
\hline 70 & $32,8 \mathrm{~A}$ & $32,8 \mathrm{~A}$ & $25,0 \mathrm{aAB}$ & $15,2 \mathrm{bC}$ & 21,6aA & $6,8 \mathrm{bB}$ & $22,2 \mathrm{a}$ & $17,4 \mathrm{AB}$ \\
\hline 160 & $41,6 \mathrm{~A}$ & $36,7 \mathrm{~A}$ & $20,2 \mathrm{bB}$ & 33,0aAB & $324,0 \mathrm{~A}$ & $19,7 \mathrm{~A}$ & $14,8 \mathrm{~B}$ & $12,4 \mathrm{~B}$ \\
\hline DMS & \multicolumn{2}{|c|}{12,2} & \multicolumn{2}{|c|}{6,8} & \multicolumn{2}{|c|}{5,9} & \multicolumn{2}{|c|}{6,8} \\
\hline CV (\%) & \multicolumn{2}{|c|}{21,5} & \multicolumn{2}{|c|}{16,6} & \multicolumn{2}{|c|}{24,1} & \multicolumn{2}{|c|}{24,8} \\
\hline \multicolumn{9}{|c|}{ Classe de diâmetro 0,8-2,0 mm } \\
\hline 10 & 42,8 & $36,6 \mathrm{~B}$ & $33,6 b$ & $49,6 \mathrm{aA}$ & $9,7 \mathrm{bC}$ & $16,3 \mathrm{aB}$ & $23,6 \mathrm{aA}$ & $14,2 \mathrm{bC}$ \\
\hline 40 & 34,2 & $38,2 \mathrm{~B}$ & 26,1 & $28,6 \mathrm{~B}$ & $14,6 \mathrm{~B}$ & $11,4 \mathrm{C}$ & 12,1B & $13,2 \mathrm{C}$ \\
\hline 70 & $40,1 \mathrm{~b}$ & 73,4aA & 27,8 & $19,2 B$ & $21,5 \mathrm{~A}$ & $17,5 B$ & $25,6 \mathrm{a}$ & $24,4 \mathrm{~B}$ \\
\hline 160 & 44,3 & $56,6 \mathrm{~A}$ & 32,3 & $46,1 \mathrm{~A}$ & $21,9 \mathrm{~A}$ & $25,2 \mathrm{~A}$ & 19,6bAB & $44,9 \mathrm{aA}$ \\
\hline DMS & \multicolumn{2}{|c|}{16,9} & \multicolumn{2}{|c|}{13,9} & \multicolumn{2}{|c|}{4,8} & \multicolumn{2}{|c|}{7,9} \\
\hline CV (\%) & \multicolumn{2}{|c|}{23,7} & \multicolumn{2}{|c|}{19,6} & 17 & 7,6 & 21 & L,9 \\
\hline
\end{tabular}


A densidade radicular não diferiu entre cultivares ao longo do tempo. Houve diferença entre épocas de amostragem para o cultivar RB83 5089 com maiores valores na segunda e quarta amostragens nos solos NV e LVA, respectivamente (Figura 19).

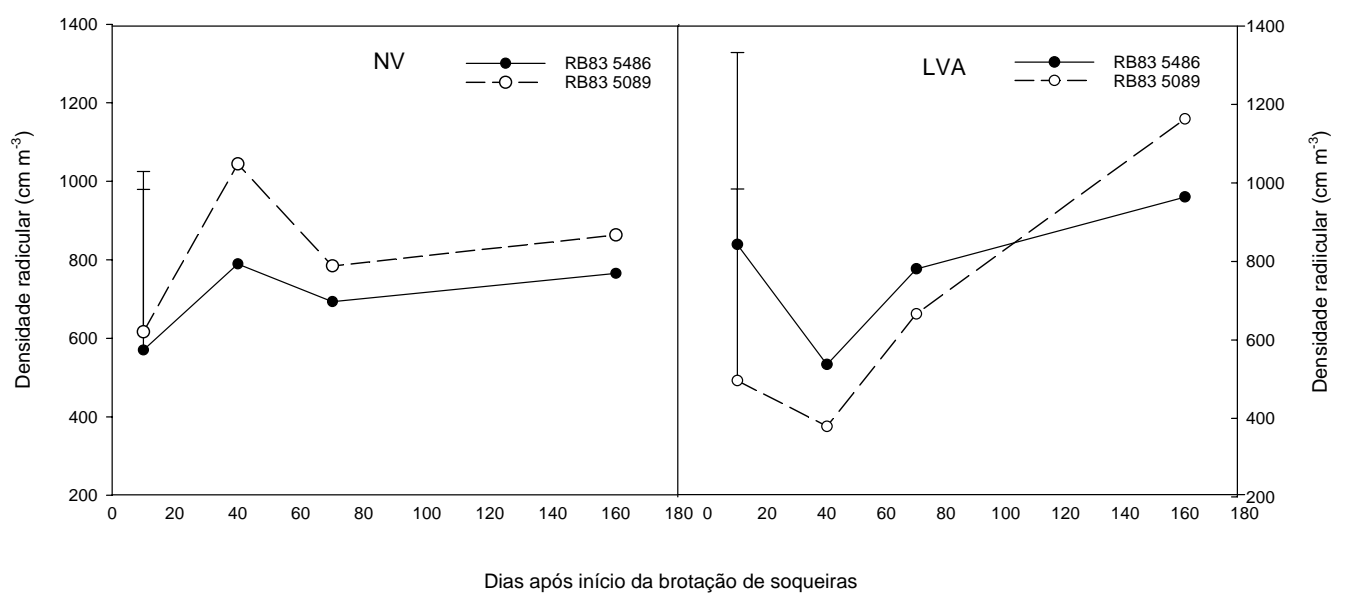

Figura 19 - Densidade radicular ao longo do tempo para os cultivares RB83 5089 e RB83 5486 nos solos NV e LVA. Barras de erro $=$ DMS $(0,05)$

Os resultados da dinâmica de crescimento de raízes, baseada no comprimento em diferentes classes de diâmetro, parecem apresentar relação com as características de precocidade dos cultivares. Sabe-se que o cultivar RB83 5089 apresenta baixa precocidade, enquanto que o RB83 5486 é considerado precoce, com rápida maturação (PMGCA, 2005b). Quando comparado ao RB83 5089, o cultivar RB83 5486 apresenta desenvolvimento inicial e entra em senescência mais rapidamente. Em solo arenoso, os efeitos da precocidade podem ser mais intensos do que em solos argilosos. Espera-se que cultivares com características de precocidade acentuadas (como o RB83 5486), comparados com cultivares não-precoces (como o RB83 5089) apresentem maior ciclagem radicular em solos com condições favoráveis à morte e decomposição de raízes. 


\subsubsection{Vitalidade radicular}

Quanto à vitalidade de raízes a partir do teste de tetrazólio, os menores valores encontrados foram da ordem de $0,25 \mathrm{mM} \mathrm{g}^{-1}$ (massa seca) de trifenilformazan (TF), e o maior valor esteve próximo a $1,2 \mathrm{mM} \mathrm{g}^{-1}$. A maioria dos trabalhos de pesquisa em que o teste enzimático com trifeniltetrazólio foi empregado para avaliar a vitalidade radicular, relacionam valores de absorbância do extrato analisado com maior ou menor atividade enzimática (Joslin \& Henderson, 1984; Clemenson-Lindell, 1994).

Outros autores avaliaram a atividade enzimática quantificando o trifenilformazan formado, encontrando valores de 10,8 $\mathrm{mM} \mathrm{TFg}^{-1}$ para raízes finas de coloração branca; 6,8 mM TF g ${ }^{-1}$ para raízes finas de coloração amarronzada e 0,1 $\mathrm{mM} \mathrm{TFg}^{-1}$ para raízes visualmente em decomposição (Ruf \& Brunner, 2003). Ao comparar os resultados com aqueles já encontrados por outros autores, constata-se que os valores obtidos nesse estudo são baixos. Entretanto, é importante considerar as diferenças entre os estudos, nos quais foram avaliadas espécies distintas em diferentes condições.

Os resultados do presente trabalho permitiram comparar a vitalidade radicular dos dois cultivares em diferentes épocas. A maior concentração de TF ocorreu para o cultivar RB83 5486 no NV na primeira amostragem, invertendo a situação na segunda coleta. Tal observação pode estar relacionada com o considerável aumento na densidade radicular do cultivar RB83 5089 ocorrido nessa mesma época (Figuras 20 e 19). A maior vitalidade radicular do RB83 5089 no NV foi verificada na segunda amostragem, enquanto que para RB83 5486, a maior vitalidade de raízes ocorreu na primeira época de amostragem (Figura 20).

No LVA houve diferença na vitalidade de raízes com maiores valores para RB83 5486 na terceira época de amostragem. Nas diferenças verificadas entre períodos, RB83 5089 apresentou maior vitalidade por ocasião da última coleta, enquanto que o cultivar RB83 5486 apresentou maior vitalidade nas três primeiras amostragens (Figura 20). 


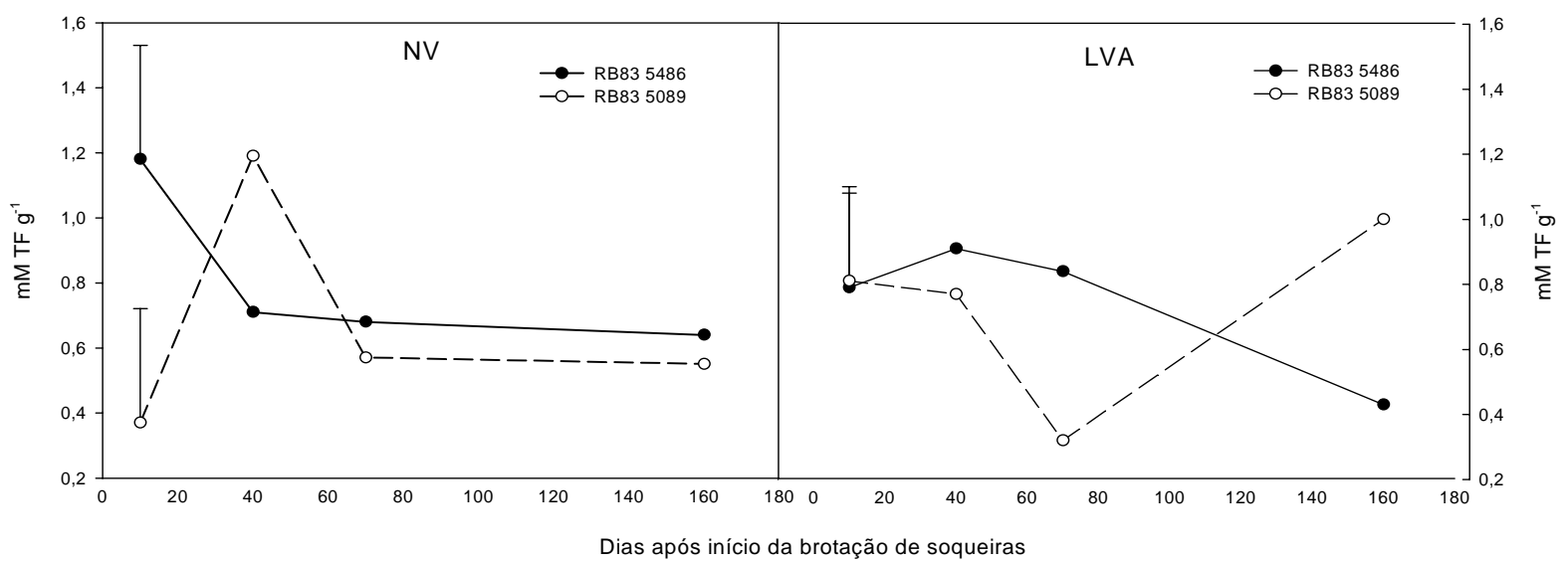

Figura 20 - Vitalidade radicular de dois cultivares de cana-de-açúcar em dois solos em função da produção de Trifenilformazan $(\mathrm{TF})$. Barras de erro = DMS $(0,05)$

A vitalidade radicular no decorrer do tempo apresentou padrão semelhante daquele encontrado para densidade de raízes, indicando maior vitalidade para o cultivar RB83 5486 em período anterior ao verificado para o RB83 5089. Essa observação confirma a relação deste parâmetro com as características de precocidade dos cultivares.

\subsection{Produtividade e qualidade tecnológica da cana-de-açúcar}

Com relação à produção de colmos e açúcar, a terceira e quarta socas apresentaram maiores valores do que a quinta soca para os dois cultivares no LVA. Já no NV, a produção de colmos foi maior para RB83 5089 nos três cortes, enquanto que a produção de açúcar foi maior para RB83 5486 na terceira e quarta socas (Tabela 9). 
Tabela 9. Produção de colmos e de açúcar em três safras para os cultivares RB83 5089 e RB83 5486 plantados em dois solos

\begin{tabular}{|c|c|c|c|c|c|c|}
\hline \multirow[t]{2}{*}{ Variedades } & \multirow{2}{*}{\multicolumn{3}{|c|}{$\begin{array}{l}\text { Produção de colmos } \\
\qquad \mathrm{Mg} \mathrm{ha}^{-1}\end{array}$}} & \multicolumn{3}{|c|}{ Produção de açúcar } \\
\hline & & & & & $\mathrm{Mg} \mathrm{ha}^{-1}$ & \\
\hline & \multicolumn{2}{|c|}{ LVA } & \multirow[b]{2}{*}{ 2003/04 } & \multicolumn{3}{|c|}{ LVA } \\
\hline & 2001/02 & $2002 / 03$ & & 2001/02 & 2002/03 & 2003/04 \\
\hline RB83 5486 & $96 \mathrm{~b}$ & $118 \mathrm{~b}$ & 65 & $18 \mathrm{a}$ & 16 & 16 a \\
\hline RB83 5089 & $112 \mathrm{a}$ & $142 \mathrm{a}$ & 72 & $17 \mathrm{~b}$ & 16 & $15 \mathrm{~b}$ \\
\hline DMS & 12 & 20 & 19 & 0,9 & 0,8 & 0,9 \\
\hline \multicolumn{4}{|c|}{ NV } & \multicolumn{3}{|c|}{$\mathrm{NV}$} \\
\hline RB83 5486 & $96 \mathrm{~b}$ & $114 \mathrm{~b}$ & $82 \mathrm{~b}$ & 16 a & 16 a & $10 \mathrm{~b}$ \\
\hline RB83 5089 & $122 \mathrm{a}$ & 135 a & $106 \mathrm{a}$ & $15 b$ & $15 \mathrm{~b}$ & $12 \mathrm{a}$ \\
\hline DMS & 8 & 12 & 10 & 0,8 & 0,9 & 1,8 \\
\hline
\end{tabular}

Médias seguidas por letras minúsculas diferentes na mesma coluna indicam diferença entre cultivares.

A elevada produção de colmos encontrada para RB83 5089 indica que esse cultivar foi mais vigoroso tanto em solo arenoso quanto argiloso. Entretanto, essas características não traduziram-se necessariamente em elevado potencial de produção de açúcar, confirmando relatos de que o cultivar RB83 5089 apresenta alta produção de colmos e que RB83 5486 apresenta elevada produção de açúcar (Gomes, 2003). O grande potencial de produção de açúcar do cultivar RB83 5486 foi descrito como característica genotípica (PMGCA, 2005b) e esse cultivar apresentou alta produção de açúcar tanto em solo com maior ou menor potencial produtivo. 


\section{CONCLUSÕES}

A partir dos resultados apresentados e considerando as condições em que o estudo foi realizado, conclui-se que:

a) O crescimento radicular de soqueiras de cana-de-açúcar ao longo do tempo variou de acordo com características de precocidade dos cultivares;

b) Efeitos da precocidade na dinâmica radicular foram mais evidentes no LVA;

c) O cultivar RB83 5486, de maior precocidade, apresentou no LVA maior comprimento de raízes, maior densidade e vitalidade radicular em período anterior ao RB83 5089;

d) Houve maior concentração de raízes até $18 \mathrm{~cm}$ das linhas de cana para os cultivares RB83 5486 e RB83 5089 até os 54 cm de profundidade no LVA;

e) No NV houve maior concentração radicular até $23 \mathrm{~cm}$ das linhas de cana para o cultivar RB83 5486, enquanto que o RB83 5089 distribuiu-se de forma mais uniforme;

f) No NV o maior comprimento radicular ocorreu até os $46 \mathrm{~cm}$ de profundidade;

g) O cultivar RB83 5486 apresentou menor redução no comprimento radicular com o aumento da profundidade no LVA;

h) O desenvolvimento diferenciado de cultivares de cana-de-açúcar alterou a concentração de hidrogênio do solo;

i) A elevada produção de colmos do cultivar RB83 5089 resultou em maior extração de nutrientes nos dois solos;

j) O cultivar RB83 5486 foi mais econômico no LVA, utilizando menor quantidade de nutrientes para produzir açúcar. 
ANEXOS 
Anexo A

Tabela 10. Tratamentos dos experimentos instalados nos solos NV e LVA

\begin{tabular}{ccc}
\hline Tratamento & Descrição NV & Descrição LVA \\
\hline 1 & SP 80-1816 & SP 80-1842 \\
2 & RB785148 & RB835486 \\
3 & SP 83-5073 & RB845257 \\
4 & RB72454 & SP 80-3280 \\
5 & SP 80-3280 & RB825336 \\
6 & RB855536 & RB72454 \\
7 & SP 80-1842 & SP 83-5073 \\
8 & RB835486 & SP 81-3250 \\
9 & SP 81-3250 & RB785148 \\
10 & RB845257 & RB855536 \\
11 & RB825336 & RB835089 \\
12 & RB835089 & SP 80-1816 \\
\hline
\end{tabular}




\section{ANEXO B}

Tabela 11. Atributos químicos de rotina na profundidade de 0-20 cm dos solos LVA e NV

\begin{tabular}{|c|c|c|c|c|c|c|c|c|c|c|c|c|c|}
\hline Tratamentos & $\begin{array}{c}\mathrm{pH} \\
\mathrm{CaCl}_{2}\end{array}$ & $\begin{array}{l}\text { M.O. } \\
\text { g dm }^{-3}\end{array}$ & \multicolumn{2}{|c|}{$\mathrm{mg} \mathrm{dm}^{-3}$} & \multicolumn{7}{|c|}{$\mathrm{mmol}_{\mathrm{C}} \mathrm{dm}^{-3}$} & \multicolumn{2}{|c|}{$\%$} \\
\hline & \multicolumn{13}{|c|}{ Latossolo Vermelho-Amarelo Distrófico psamítico (LVA) } \\
\hline RB83 5486 & 4,4 & 17,0 & 10,6 & 33,6 & 5,6 & 7,2 & 3,6 & 4,2 & 33,8 & 16,4 & 50,2 & 32,4 & 22,0 \\
\hline RB83 5089 & 4,7 & 17,0 & 10,6 & 34,8 & 6,2 & 13,0 & 5,4 & 2,2 & 26,8 & 24,6 & 51,4 & 47,8 & 8,4 \\
\hline $\mathrm{F}$ & $1,16 \mathrm{~ns}$ & $1,1 \mathrm{~ns}$ & 1,3 ns & $0,6 \mathrm{~ns}$ & $0,7 \mathrm{~ns}$ & $1,0 \mathrm{~ns}$ & $1,1 \mathrm{~ns}$ & $1,4 \mathrm{~ns}$ & 1,3ns & $1,3 \mathrm{~ns}$ & $0,9 \mathrm{~ns}$ & $1,0 \mathrm{~ns}$ & $1,2 \mathrm{~ns}$ \\
\hline \multirow[t]{2}{*}{$\mathrm{CV}(\%)$} & 7,40 & 8,8 & 30,7 & 35,3 & 19,4 & 36,10 & 40,26 & 44,05 & 51,6 & 19,3 & 29,2 & 33,0 & 51,0 \\
\hline & \multicolumn{13}{|c|}{ Nitossolo Vermelho Eutroférrico latossólico (NV) } \\
\hline RB83 5486 & $5,4 \mathrm{a}$ & 26,6 & 7,4 & 141,4 & 7,6 & 46,4 & 15,8 & - & $29,8 \mathrm{~b}$ & 69,8 & 99,6 & 69,6 & - \\
\hline RB83 5089 & $4,8 \mathrm{~b}$ & 27,0 & 7,8 & 148,6 & 6,7 & 30,8 & 9,0 & - & 43,4 a & 46,5 & 89,9 & 51,4 & - \\
\hline $\mathrm{F}$ & $1,7^{*}$ & $1,2 \mathrm{~ns}$ & $0,6 \mathrm{~ns}$ & $1,7 \mathrm{~ns}$ & $1,5 \mathrm{~ns}$ & $1,2 \mathrm{~ns}$ & $0,8 \mathrm{~ns}$ & - & $1,6 *$ & $1,1 \mathrm{~ns}$ & 1,2 ns & $1,6 \mathrm{~ns}$ & - \\
\hline $\mathrm{CV}(\%)$ & 5,2 & 8,9 & 46,8 & 25,8 & 30,2 & 22,6 & 38,0 & - & 17,2 & 23,6 & 10,5 & 12,2 & - \\
\hline
\end{tabular}

Médias de cinco repetições contidas em colunas, seguidas da mesma letra, não diferem entre si pelo Teste de Tukey.

* e **: nível de significância de 5 \% e 1\% respectivamente. ns: não significativo. Al e m\%: valores nulos no NV. 


\section{ANEXO C}

Tabela 12. Atributos químicos de rotina na profundidade de $20-40 \mathrm{~cm}$ dos solos LVA e NV

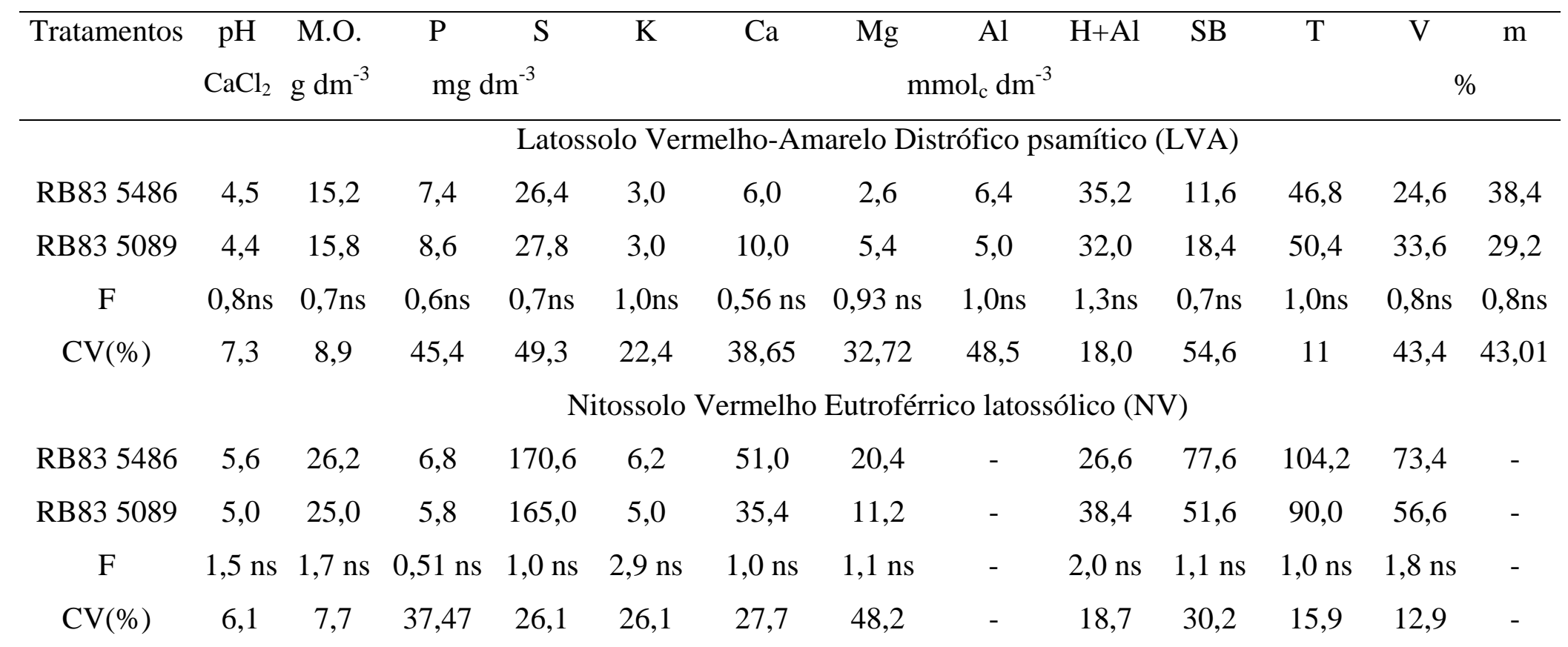

Médias de cinco repetições contidas em colunas, seguidas da mesma letra, não diferem entre si pelo Teste de Tukey. * e **: nívelde significância de 5 \% e 1\% respectivamente. ns: não significativo. Al e m\%: valores nulos no NV. 
ANEXO D

Tabela 13. Teor de micronutrientes na profundidade de $0-20 \mathrm{~cm}$ dos solos LVA e NV

\begin{tabular}{cccccc}
\hline Tratamentos & $\mathrm{B}$ & $\mathrm{Cu}$ & $\mathrm{Fe}$ & $\mathrm{Mn}$ & $\mathrm{Zn}$ \\
& \multicolumn{5}{c}{$\mathrm{mg} \mathrm{dm}^{-3}$} \\
Latossolo Vermelho-Amarelo Distrófico psamítico (LVA) \\
RB83 5486 & 0,2 & 0,3 & 62,8 & 6,2 & 0,3 \\
RB83 5089 & 0,1 & 0,3 & 49,0 & 5,8 & 0,2 \\
F & $1,0 \mathrm{~ns}$ & $0,8 \mathrm{~ns}$ & $0,9 \mathrm{~ns}$ & $1,2 \mathrm{~ns}$ & $1,0 \mathrm{~ns}$ \\
CV(\%) & 19,0 & 22,8 & 22,8 & 20,6 & 32,6 \\
RB83 5486 & 0,2 & 9,5 & 24,0 & 128,2 & 0,5 \\
RB83 5089 & 0,4 & 10,1 & 30,6 & 125,8 & 0,5 \\
F & $2,6 \mathrm{~ns}$ & $2,1 \mathrm{~ns}$ & $1,0 \mathrm{~ns}$ & $0,6 \mathrm{~ns}$ & $0,9 \mathrm{~ns}$ \\
CV(\%) & 20,6 & 11,0 & 19,01 & 40,8 & 32,3 \\
\hline
\end{tabular}

Médias de cinco repetições contidas em colunas, seguidas da mesma letra, não diferem entre si pelo Teste de Tukey. * e **: nível de significância de 5\% e 1\% respectivamente. ns: não significativo. 
ANEXO E

Tabela 14. Teor de micronutrientes na profundidade de 20-40 cm dos solos LVA e NV

\begin{tabular}{cccccc}
\hline Tratamentos & B & $\mathrm{Cu}$ & $\begin{array}{c}\mathrm{Fe} \\
\mathrm{mg} \mathrm{dm}^{-3}\end{array}$ & $\mathrm{Mn}$ \\
& \multicolumn{5}{c}{ Latossolo Vermelho-Amarelo Distrófico psamítico (LVA) } \\
RB83 5486 & 0,14 & 0,2 & 48,8 & 4,1 & 0,2 \\
RB83 5089 & 0,14 & 0,2 & 48,0 & 3,3 & 0,4 \\
F & $2,4 \mathrm{~ns}$ & $0,5 \mathrm{~ns}$ & $0,5 \mathrm{~ns}$ & $0,9 \mathrm{~ns}$ & $1,4 \mathrm{~ns}$ \\
CV(\%) & 11,2 & 25,1 & 23,6 & 188,9 & 47,4 \\
RB83 5486 & 0,2 & 9,3 & 19,0 & 83,8 & 0,4 \\
RB83 5089 & 0,3 & 9,7 & 25,4 & 102,4 & 0,3 \\
F & $1,0 \mathrm{~ns}$ & $2,4 \mathrm{~ns}$ & $1,5 \mathrm{~ns}$ & $1,5 \mathrm{~ns}$ & $2,4 \mathrm{~ns}$ \\
CV(\%) & 28,6 & 10,7 & 18,2 & 37,1 & 35,0 \\
\hline
\end{tabular}

Médias de cinco repetições contidas em colunas, seguidas da mesma letra, não diferem entre si pelo Teste de Tukey. * e **: nível de significância de 5\% e 1\% respectivamente. ns: não significativo. 


\section{REFERÊNCIAS BIBLIOGRÁFICAS}

ABREU, C.A. de; ABREU, M.F. de; ANDRADE, J.C. Determinação de cobre, ferro, manganês, zinco, cádmio, cromo, níquel e chumbo em solos usando a solução DTPA em pH 7,3. In: RAIJ, B. van; ANDRADE, J.C. de; CANTARELLA, H.; QUAGGIO, J.A. (Ed.). Análise química para avaliação da fertilidade de solos tropicais. Campinas: Instituto Agronômico, 2001b. cap. 16, p. 240-250.

ABREU, M.F. de; ABREU, C.A. de; ANDRADE, J.C. Determinação de boro em água quente, usando aquecimento com microonda. In: RAIJ, B. van; ANDRADE, J.C. de; CANTARELLA, H.; QUAGGIO, J.A. (Ed.). Análise química para avaliação da fertilidade de solos tropicais. Campinas: Instituto Agronômico, 2001a. cap. 15, p. 231-239.

ALVAREZ, I.A.; CASTRO, P.R.C.; NOGUEIRA, M.C.S. Crescimento de raízes de cana crua e queimada em dois ciclos. Scientia Agrícola, v. 57, n. 4, p. 653-659, 2000.

ANGHINONI, I.; VOLKART, C.R.; FATTORE, N.; ERNANI, P.R. Morfologia de raízes e cinética da absorção de nutrientes em diversas espécies e genótipos de plantas. Revista Brasileira de Ciência do Solo, v. 13, p. 355-361, 1989.

AVILAN R., L.R. Estudio del sistema radicular de la cana de azucar variedad V58-4 en un mollisol del estado Portuguesa. Agronomia Tropical, v.28, n.2, p.163-174, 1978. 
AVILAN, L. R.; GRANADOS F. M.; ORTEGA, D. Estudio del Sistema Radicular de Tres Variedades de Caña de Azúcar (Saccharum spp.) en un Mollisol de los Valles de Aragua. Agronomia Tropical, v. 27, n. 1, p. 69-87, 1977.

BALL-COELHO, B.; SAMPAIO, E.V.S.B; TIESSEN, H.; STEWART, J.W.B. Root dynamics in plant and ratoon crops of sugar cane. Plant and Soil, v. 142, p. 297-305, 1992.

BENNIE, A.T.P. Growth and mechanical impedance. In: WAISEL, Y.; ESHEL, A.; KAFKAFI, U. (Ed.) Plant roots: The hidden half. New York: Marcel Dekker, 1996. cap. 23, p. 453-470.

BEUSICHEM, M.L.van Nutrient absorption by pea plants during dinitrogen fixation. 1. Comparison with nitrate nutrition. Netherlands Journal of Agricultural Science, v. 29, p. 259-273, 1981.

BITTENCOURT, V.C.; ORLANDO FILHO, J.; ZAMBELLO Júnior., E. Determination of available $\mathrm{P}$ for sugarcane in tropical soils by extraction with $\mathrm{H}_{2} \mathrm{SO}_{4} 0,5 \mathrm{~N}$. In: CONGRESS OF THE INTERNATIONAL SOCIETY OF SUGARCANE TECHNOLOGISTS, 16, São Paulo, 1977. Proceedings. São Paulo: S. Ed., 1978. v. 2, p. $1175-1186$.

BLAKE, G.R.; HARTGE, K.H. Bulk density. In: KLUTE, A. (Ed.). Methods of soil analysis: physical and mineralogical methods. 2 ed. Madison: American Society of Agronomy, 1986. cap. 13, p. 363-375.

BÖHM, W. Methods of studying root systems. Berlin: Springer-Verlag, 1979. 188 p. 
BOONE, F.R.; H.M.G. van der WERF, H.M.G.; KROESBERGEN, B.; HAG, T. BOERS, A. The effect of compaction of the arable layer in sandy soil on the growth of maize for silage. 1 Critical matric water potentials in relation to soil aeration and mechanical impedance. Netherlands Journal of Agricultural Sciences, v. 34, p. 155-171, 1986.

BRADFORD, J.M. Penetrability. In: KLUTE, A. (Ed.). Methods of soil analysis: Physical and mineralogical methods. 2 ed. Madison: American Society of Agronomy, 1986. cap. 19, p. 463-478.

BRADY, N.C.; WEIL, R. The nature and properties of soils. New Jersey: Prentice Hall, 1999. 881 p.

BRAUNACK, M.V.; PEATEY, T.C. Changes in soil physical properties after one pass of a sugarcane haulout unit. Autralian Journal of Experimental Agriculture, v. 39, p. 733-742, 1999.

CANNON, J.; CANNON, M. Dye Plants and dyeing. London: A \& C Black, 1994. 128 p. 1994.

CANTARELLA, H.; QUAGGIO, J.A. Determinação da matéria orgânica. In: RAIJ, B. van; ANDRADE, J.C. de; CANTARELlA, H.; QUAGgIO, J.A. (Ed.). Análise química para avaliação da fertilidade de solos tropicais. Campinas: Instituto Agronômico, 2001. cap. 9, p. 173-180.

CANTARELLA, H.; RAIJ, B. van; COSCIONE, A.R.; ANDRADE, J.C. Determinação de alumínio, cálcio e magnésio trocáveis em extrato de cloreto de potássio. In: RAIJ, B. van; ANDRADE, J.C. de; CANTARELLA, H.; QUAGGIO, J.A. (Ed.). Análise química para avaliação da fertilidade de solos tropicais. Campinas: Instituto Agronômico, 2001. cap. 13 p. 213-224. 
CASAGRANDE, A.A. Tópicos de morfologia e fisiologia da cana-de-açúcar. Jaboticabal: FUNEP, 1991. 157 p.

CLEMENSSON-LINDELL, A. Triphenyltetrazolium chloride as an indicator of fineroot vitality and environmental stress in coniferous forest stands: Applications and limitations. Plant and Soil, v. 159, p. 297-300, 1994.

COLETI, J.T.; STUPIELLO, J.J.; OLIVEIRA, G. R. D.; CASAGRANDE, J. C.; RIBEIRO, L. D. Remoção de macronutrientes pela cana-planta e cana-soca em Argissolos, variedades RB 835486 e SP 813250. In: CONGRESSO NACIONAL DA SOCIEDADE DOS TÉCNICOS AÇUCAREIROS E ALCOOLEIROS DO BRASIL, 8., Recife, 2002. Anais. Recife: STAB, 2002. p. 316-321

COMAS, L. H.; EISSENSTAT, D. M.; LAKSO, A. Assessing root death and root system dynamics in a study of grape canopy pruning. New Phytologist, v. 147, p. 171-178, 2000.

CONN, H. J. Biological Stains: a handbook on the nature and uses of the dyes employed in the biological laboratory. Baltimore: Williams \& Willkins, 1969. 480 p.

CORRÊA, J.B.D.; ANDRADE, L.A.B.; DIAS JÚNIOR, M.; ALVES, V.G. Influência da compactação na concentração de nutrientes da parte aérea da cana-de-açúcar em três tipos de solo. STAB - Açúcar, álcool e subprodutos, v. 19, n. 5, p. 34-37, 2001.

CORRÊA, J.B.D.; ANDRADE, L.A.B.; DIAS JÚNIOR, M.; ALVES, V.G. Efeitos da compactação de três tipos de solos no rendimento de matéria seca de duas variedades de cana-de-açúcar, em condições de casa de vegetação. STAB - Açúcar, álcool e subprodutos, v. 18, n. 2, p. 32-34, 1999. 
COSCIONE, A.R.; ANDRADE, J.C.; RAIJ, B. van; ABREU, M.F. de; CANTARELLA, H. Determinação de alumínio, cálcio, magnésio, sódio e potássio trocáveis em extrato de cloreto de amônio. In: RAIJ, B. van; ANDRADE, J.C. de; CANTARELLA, H.; QUAGGIO, J.A. (Ed.). Análise química para avaliação da fertilidade de solos tropicais. Campinas: Instituto Agronômico, 2001. cap. 10, p. 181-188.

CRESTANA, S.; GUIMARÃES, M.F. JORGE, L.A.C.; RALISCH, R.; TOZZI, C.L.; TORRE NETO, A.; VAZ, C.M.P. Avaliação da distribuição de raízes no solo auxiliada por processamento de imagens digitais. Revista Brasileira de Ciência do Solo, v.18, p. 365-371, 1994.

DART, P.J.; MERCER, F.V. The legume rhizosphere. Archives of Microbiology, v. 47, p. 344-378, 1964.

DIAS, F. L. F. Relação entre produtividade, clima, solos e variedades de cana-de-açúcar, na região noroeste do Estado de São Paulo. Piracicaba, 1997. 61 p. Dissertação (mestrado) - Escola Superior de Agricultura “Luiz de Queiroz” - Universidade de São Paulo.

DILLEWIJN, C. van. Botany of Sugarcane, Waltham: Chronica Botanica, 1952. 371 p.

DUNBABIN, V.; RENGEL, Z.; DIGGLE, A. The root growth response to heterogeneous nitrate supply differs for Lupinus angustifolius and Lupinus pilosus. Australian Journal of Agricultural Research, v. 52, p. 495-503, 2001.

EMPRESA BRASILEIRA DE PESQUISA AGROPECUÁRIA. Centro Nacional de Pesquisa de Solos. Sistema brasileiro de classificação de solos. Rio de Janeiro, 1999. 412p. 
EVANS, H. The root-system of the sugarcane I. Methods of study. The Empire Journal of Experimental Agriculture, v. 3, n. 12, p. 351-362, 1935.

FARONI, C.E. Sistema radicular de cana-de-açúcar e identificação de raízes metabolicamente ativas. Piracicaba, 2005. 68 p. Dissertação (Mestrado) - Escola Superior de Agricultura "Luiz de Queiroz” - Universidade de São Paulo.

FERNANDES, J. Observações sobre o sistema radicular da cana-de-açúcar. Álcool \& Açúcar, v.5, n.23, p.51-52, 1985.

FERNANDES, J.; RIPOLI, T.C.; MILLAN, M. A compactação dosolo e a brotação das soqueiras. Álcool e Açúcar, v. 3, n. 12, p. 12-17, 1983.

FERNANDES, S.A.P.; BERNOUX, M.; CERRI, C.C.; FEIGL, B.J.; PICCOLO, M. Seasonal variation of soil chemical properties and $\mathrm{CO}_{2}$ and $\mathrm{CH}_{4}$ fluxes in unfertilized and P-fertilized pastures in an Ultisol of the Brazilian Amazon. Geoderma, v. 107, p. 227-241, 2002.

FNP CONSULTORIA \& COMÉRCIO. Agrianual 2005: anuário da agricultura brasileira. São Paulo, 2005. 520 p.

GAHOONIA, T.S.; NIELSEN, N.E. The root induced $\mathrm{pH}$ change on the depletion of inorganic and organic phosphorus in the rhizosphere. Plant and Soil, v. 143, p. 183189, 1992.

GALLO, J.R. Amostragem em cana-de-açúcar para fins de análise foliar. Bragantia, v. 21, n.54, p.899-921, 1962. 
GARDNER, W.H. Water content. In: KLUTE, A. (Ed.). Methods of soil analysis: physical and mineralogical methods. 2 ed. Madison: American Society of Agronomy, 1986. cap. 21, p. 493-544.

GEE, G.W.; BAUDER, J.W. Particle-size analysis. In: KLUTE, A. (Ed.). Methods of soil analysis: physical and mineralogical methods. 2 ed. Madison: American Society of Agronomy, 1986. cap. 15, p. 383-409.

GOLDSTEIN, A.H.; DAVON, A.; BAERTLEIN, D.A.; McDANIEL, R.G. Phosphate starvation inducible metabolism in Lycopersicon esculentum II Characterization of the phosphate starvation inducible-excreted acid phosphatase. Plant Physiology, v. 87, p. 716-720, 1998.

GOMES, J.F.F. Produção de colmos e exportação de macronutrientes primários por cultivares de cana-de-açúcar (Saccharum spp.). Piracicaba, 2003. 65 p. Dissertação (Mestrado) - Escola Superior de Agricultura "Luiz de Queiroz” - Universidade de São Paulo.

GREGORY, C.J.; CRAWFOR, D.V.; MCGOWAN, M. Nutrient relations of winter wheat. II Movement of nutrients to the root and their uptake. Journal of Agricultural Science, v. 93, p. 495-504, 1979.

GUIMARÃES, M.F.; JORGE, L.A.C.; DE MARIA, I.C.; TAVARES FILHO, J.; BICUDO, S.J.; CRESTANA, S. Três metodologias de avaliação de raízes: descrição, limitações e vantagens. In: SIMPÓSIO NACIONAL DE INSTRUMENTAÇÃO AGROPECUÁRIA - SIAGRO, 1., São Carlos, 1996. Anais. São Carlos: EMBRAPA - CNPDIA, 1997. p. 295-304. 
HAISE, H.R.; HAAS, H.J.; JENSEN, L.R. Soils moisture studies of some great plains soils. II Field Capacity as related to 1/3- atmosphere percentage, and minimun point as related to 15- and 26- atmosphere percentage. Soil Science Society of America Proceedings, v. 34, p. 20-25, 1955.

HACKETT, C. A study of the root system of barley. I Effects of nutrition on two varieties. New Phytologist, v. 67, p. 287-299, 1968.

HARRISON-MURRAY, R.S.; CLARKSON, D.T. Relationships between structural development and the absorption of ions by the root system of Cucurbita pepo, Planta, n. 114, p. 1-16, 1973.

HAUCK, F.W.; DICKINSON, J. Conveniência y experimentacion con potasio en el cultivo de caña de azucar. ATAC - Revista Técnica Informativa, v. 13, p. 626-635, 1954.

HIMMELBAUER, M.L.; LOISKANDL, W.; KASTANEK, F. Estimating length, average diameter and surface area of roots using two different image analyses systems. Plant and Soil, v. 26, n. 1-2, p. 111-120, 2004.

HUMBERT, R.P. El cultivo de la caña de azucar. México: Continental, 1974. 719 p.

INFORZATO, R.; ALVAREZ, R. Distribuição do sistema radicular da cana-de-açúcar variedade Co. 290, em solo tipo terra-roxa-legítima. Bragantia, v. 16, n. 1, p. 1-13, 1957.

INGRAM, K.T.; LEERS, G.A. Software for measuring root characters from digital images. Agronomy Journal, v. 93, p. 918-922, 2001. 
JACQUES, W. A.; SCHWASS, R. H. Root development in some common New Zealand pasture plants. VII Seasonal root replacement in perennial ryegrass (Lolium perenne), Italian ryegrass (L. multiflorum) and tall fescue (Festuca arundinaceae). New Zealand Journal of Science and Technology, v. 37, p. 569-583, 1956.

JARVIS, S.C.; HATCH, D.J. Rates of hydrogen efflux by nodulated legumes grown in flowing solution culture with continuous $\mathrm{pH}$ monitoring and adjustment. Annals of Botany, v. 55, p. 41-51, 1985.

JENNY, H.; GROSSENBACHER, K. Root soil boundary zones as seen in the electron microscope. Procedures of Soil Science Society of America, v. 27, p. 273-277, 1963.

JOHNSON, J.F.; ALLAN, D.L.; VANDE, C.P.; WEIBLEN, G. Root carbon dioxide fixation by phosphorus-deficient Lupinus albus: contribution to organic acid exudation by proteoid roots. Plant Physiology, v. 112, p. 19-30, 1996.

JORGE, L.A.C.; CRESTANA, S. SIARCS 3.0: novo aplicativo para análise de imagens digitais aplicado à ciência do solo (Compact Disc). In: CONGRESSO LATINO AMERICANO DE CIÊNCIA DO SOLO, 13. Águas de Lindóia - SP, 1996. Resumos. Campinas: SBCS, 1996. 5 p.

JORNALCANA. Procana. Conteúdo. http://www.procana.com.br/Conteudo/Conheça\%20o\%20setor.asp (20 jun.2005).

JOSLIN, J. D.; HENDERSON, G. S. The determination of percentages of living tissue in woody fine root samples using triphenyltetrazolium chloride. Forestry Science, v. 30, n. 4, p. 965-970, 1984. 
JOURDAN, C.; REY, H. Modeling and simulation of the architecture and development of the oil-palm (Eloeis guinensis Jacq.) root system. Plant and soil, v.190, p. 253246, 1997.

JUNIPER, B. E.; GROVES, S.; LANDAU-SCHACHAR, B.; AUDUS, L.J. Root cap and the perception of gravity. Nature, v. 209, p. 93-94, 1966.

KHAN, D.F.; PEOPLES, M.B.; SCHWENKE, G.D.; FELTON, W.; CHEN, D.; HERRIDGE, D. Effects of below-ground nitrogen on $\mathrm{N}$ balances of field-grown fababean, chickpea, and barley. Australian Journal of Agricultural Research, v. 54, p. 333-340, 2003.

KHAN, D.F.; PEOPLES, M.B; CHALK, P.M.; HERRIDGE, D.F. Quantifying belowground nitrogen of legumes. 2. A comparison of ${ }^{15} \mathrm{~N}$ and non isotopic methods. Plant and Soil, v. 237, p. 277-289, 2002.

KIMURA, K.; KIKUCHI, S.; YAMASAKI, S. Accurate root length measurement by image analysis. Plant and Soil. n. 216, p. 117-127, 1999.

KNIEVEL, D. P. Procedure for estimating ratio of live to dead root dry matter in root on samples. Crop Science, v. 13, p. 124-126, 1973.

KLUTE, A. Water retention: laboratory methods. In: KLUTE, A. (Ed.). Methods of soil analysis: physical and mineralogical methods. Madison: American Society of Agronomy, 1986. cap. 26, p. 635-660.

LEÃO, T.P. Intervalo hídrico ótimo em diferentes sistemas de pastejo e manejo da pastagem. Piracicaba, 2002. 58 p. Dissertação (Mestrado) - Escola Superior de Agricultura “Luiz de Queiroz” - Universidade de São Paulo. 
LEE, H.A. The distribution of the roots of sugarcane in the soil in the Hawaiian Islands. Plant Physiology, v. 1, p. 363-378, 1926.

LEISER, A.T. A mucilaginous root sheath in Ericaceae. American Journal of Botany, v. 55, p. 391-398, 1968.

LIBARDI, P.L. Dinâmica da água no solo. 2 ed. Piracicaba: ESALQ, Depto de Ciencias Exatas, 2000. 509 p.

LIU, W.C.; LUND, L.J.; PAGE, A.L. Acidity produced by leguminous plants through symbiotic dinitrogen fixation. Journal of Environmental Quality, v. 18, p. 529-534, 1989.

LOPES, M.A.; LANDRAU JÚNIOR, P. Influence of fertilizers on sucrose content of sugarcane. Sugar, v. 47, n. 11, p. 49-51, 1952.

MA, Q.; RENGEL, Z.; KUO, J. Aluminium toxicity in rye (Secale cereale): Root growth and dynamics of cytoplasmic $\mathrm{Ca}^{2+}$ in intact root tips. Annals of Botany, v. 89, p. 241-244, 2002.

MALAVOLTA, E. Fertilizing for high yield sugarcane. Basel: IPI, 1994. 104 p. (Bulletin, 14).

MALAVOLTA, E.; VITTI, G.C.; OLIVEIRA, S.A. de. Avaliação do estado nutricional das plantas: princípios e aplicações. 2.ed. Piracicaba: POTAFOS, 1997. 319 p.

MANHÃES, M.S.; GLORIA, N.A. Fósforo disponível para cana-de-açúcar (Saccharum spp) em solos do Estado do Rio de Janeiro. Brasil açucareiro, v. 96, p. 21-30, 1980. 
MAPFUMO, E.; CHANASYK, D.S.; NAETH, M.A.; BARON, V.S. Forage growth and yield components as influenced by subsurface compaction. Agronomy Journal, v. 90, p. 805-812, 1998.

MARSCHNER, H. Mineral nutrition of higher plants. London: Academic Press, 1995. 889 p.

MARSCHNER, H.; RÖMHELD, V. Root-induced changes in the availability of micronutrients in the rhizosphere. In: WAISEL, Y.; ESHEL, A.; KAFKAFI, U. (Ed.) Plant roots: The hidden half. New York: Marcel Dekker, 1996. cap. 28, p. 557-579.

MAULE, R.F.; MAZZA, J.A.; MARTHA Júnior, G.B. Produtividade agrícola de cultivares de cana-de-açúcar em diferentes solos e épocas de colheita. Scientia Agrícola, v. 58, n. 2, p. 295-301, 2001.

McLAY, C.D.A.; BARTON, L.; TANG, C. Acidification potential of ten grain legume species grown in nutrient solution. Australian Journal of Agricultural Research, v. 48, p. 1025-1032, 1997.

McNEILL, A.M.; ZHU, C.; FILLERY, I.R.P. A new approach to quantifying the N benefit from pasture legumes to succeeding wheat. Australian Journal of Agricultural Research, v. 49, p. 427-436, 1998.

NEWMAN, E.I. A method of estimating the total length of root in a sample. Journal of Applied Ecology, n. 3, p. 139-145, 1966.

NOORDWIJK, M van; FLORIS, J. Loss of dry weight during washing and storage of root samples. Plant and Soil, n.53, p. 239-243, 1979. 
NYE, P.H. Changes of $\mathrm{pH}$ across the rhizosphere induced by roots. Plant and Soil, v. 61, p. 7-26, 1981.

ORLANDO FILHO, J.; HAAG, H.P.; ZAMBELLO JUNIOR, E. Crescimento e absorção de macronutrientes pela cana-de-açúcar, variedade CB41-76, em função da idade, em solos do Estado de São Paulo. Boletim Técnico Planalsucar, v. 2, n. 1, p. 1-128, 1980.

PMGCA - PROGRAMA DE MELHORAMENTO GENÉTICO DA CANA-DEAÇÚCAR.- senso varietal. http://pmgca.dbv.cca.ufscar.br/htm/catal/censovar.php (20 jun.2005a).

PMGCA - PROGRAMA DE MELHORAMENTO GENÉTICO DA CANA-DEAÇÚCAR.- catálogo de variedades. http://pmgca.dbv.cca.ufscar.br/htm/catal/catvaried.php (20 jun.2005b).

QUAGGIO, J.A.; RAIJ, B. van Determinação de pH em cloreto de cálcio e da acidez total. In: RAIJ, B. van; ANDRADE, J.C. de; CANTARELLA, H.; QUAGGIO, J.A. (Ed). Análise química para avaliação da fertilidade de solos tropicais. Campinas: Instituto Agronômico, 2001. cap. 10, p. 181-188.

QUAGGIO, J.A.; RAMOS, V.J.; BATAGLIA, O.C.; RAIJ, B.van; SAKAI, M. Calagem para a sucessão batata-triticale-milho usando calcário com diferentes teores de magnésio. Bragantia, v. 44, p. 291-406, 1985.

QUEIROZ-VOLTAN, R.B.; DO PRADO, H.; MORETTI, F.C. Aspectos estruturais de raízes de cana-de-açúcar sob efeito da compactação do solo. Bragantia, v. 57, n. 1, p. 49-55, 1998. 
RAIJ, B.van Fertilidade do solo e adubação. Piracicaba: Editora Agronômica Ceres, 1991. 343 p.

RAIJ, B. Van; QUAGGIO, J.A. Determinação de fósforo, cálcio, magnésio e potássio extraídos com resina trocadora de íons. In: RAIJ, B. van; ANDRADE, J.C. de; CANTARELlA, H.; QUAGGIO, J.A. (Ed). Análise química para avaliação da fertilidade de solos tropicais. Campinas: Instituto Agronômico, 2001. cap. 11, p. 188-199.

RAIJ, B. van; QUAGGIO, J.A; CANTARELLA, H.; FERREIRA, M.E.; LOPES, A.S.; BATAGLiA, O.C. Análise química do solo para fins de fertilidade. Campinas: Fundação Cargill, 2001. 170p.

REICHARDT, K. Dinâmica da matéria e da energia em ecossistemas. Piracicaba: USP/ESALQ. Depto. Física e Meteorologia, 1996. 505 p.

ROSOLEM, C.A.; FOLONI, J.S.S.; TIRITAN, C.S. Root growth and nutrient accumulation in cover crops as affected by soil compaction. Soil and Tillage Research, v. 65, n. 1, p. 109-115, 2002.

RUF, M.; BRUNNER, I. Vitality of tree fine roots: reevaluation of the tetrazolium test. Tree Physiology, v. 23, p. 257-263, 2003.

RUSSELL, R.S. Plant root systems: Their function and interaction with the soil. England: McGraw-Hill, 1977. 290 p.

RUSSELL, C.A.; FILLERY, R.P. Estimates of lupin below-ground biomass nitrogen, dry matter, and nitrogen turnover to wheat. Australian Journal of Agricultural Research, v. 47, p. 1047-1059, 1996. 
SÃO PAULO (Estado). Secretaria de Serviços e Obras Públicas. Atlas Pluviométrico do Estado de São Paulo. São Paulo, 1972. 83 p.

SCHACHTMAN, S.P.; REID, R.J.; AYLING, S.M. Phosphorus uptake by plants: from soil to cell. Plant Physiology, v. 116, p. 447-453, 1998.

SCHALLER, G. pH changes in the rhizosphere in relation to the pH-buffering of soils. Plant and Soil, v. 97, p. 439-444, 1987.

SILVA, L.C.F.; CASAGRANDE, J.C. Nutrição Mineral da cana-de-açúcar (Macronutrientes). In: ORLANDO FILHO, J. (Coord.). Nutrição e adubação da cana-de-açúcar no Brasil. Piracicaba: Instituto do Açúcar e do Álcool, 1983. cap. 4, p. 77-99.

SILVEIRA, P.M.; ZIMMERMANN, J.P. SILVA, S.C.; CUNHA, A.A. Amostragem e variabilidade espacial de características químicas de um Latossolo submetido a diferentes sistemas de preparo. Pesquisa Agropecuária Brasileira, v. 25, n. 10, p. 2057-2064, 2000.

SPAULL, V.W.; CADET, P. Nematode parasites of sugarcane. In: LUC, M.; SIKORA, R.A.; BRIDGE, J. (Ed.). Plant parasitic nematodes in subtropical and tropical agriculture. Wallingford: International Institure of Parasitology, 1993. cap. 14, p. 461-491.

STEPONKUS, P. L.; LANPHEAR, F. O. Refinement of the triphenyltetrazolium chloride method of determining cold injury. Plant Physiology, v. 42 p. 1423-1426, 1967.

STOLZY, L.H.; BARLEY, K.P. Mechanical resistance encountered by roots entering compact soils. Soil Science, v. 105, p. 297-301, 1968. 
SYERS, J.K.; EVANS, T.D.; WILLIAMS, J.D.; MURDOCH, J. Phosphate sorption parameters of representative soils from Rio Grande do Sul, Brazil. Soil Science, v. 112, n. 3, p. 267-275, 1971.

TANG, C.; RENGEL, Z. Role of plant cation/anion uptake ratio in soil acidification. In: RENGEL, Z. (Ed.). Handbook of Soil Acidity. New York: Marcel Dekker, 2003. p. 57-81.

TENNANT, D. A test of a modified line intersect method of estimating root length. Journal of Ecology, n.63, p. 995-1001, 1975.

THOMAZI, M.D. Fixação de fosfato por solos do município de Piracicaba. Piracicaba, 1988. 67 p. Tese (Doutorado) - Escola Superior de Agricultura "Luiz de Queiroz” Universidade de São Paulo.

TOPP, G. C.; ZEBCHUK, W. The determination of soil water desorption curves for soil cores. Canadian Journal of Soil Science, v. 59, p. 19-26, 1979.

VASCONCELOS, A.C.M. Desenvolvimento do sistema radicular e da parte aérea de socas de cana-de-açúcar sob dois sistemas de colheita: crua mecanizada e queimada manual. Jaboticabal, 2002. 140 p. Tese (Doutorado) - Faculdade de Ciências Agrárias e Veterinárias - Universidade Estadual Paulista “Júlio de Mesquita Filho”

VASCONCELOS, A. C. M.; CASAGRANDE, A.A.; PERECIN, D.; JORGE, L.A.; LANDELL, M.G.A. Avaliação do sistema radicular da cana-de-açúcar por diferentes métodos. Revista Brasileira de Ciência do Solo, v. 27, p. 849-858, 2003.

VEIHMEYER, F.J.; HENDRICKSON, A.H. Methods of measuring field capacity and wilting percentages of soils. Soil Science, v. 68, p. 75-94, 1949. 
VEIHMEYER, F.J.; HENDRICKSON, A.H. Soil density and root penetration. Soil Science, v. 65, p. 487-493, 1948.

VITTI, G.C. Avaliação e interpretação do enxofre no solo e na planta. Jaboticabal: FUNEP, 1988. 37 p.

WAISEL, Y.; ESHEL, A.; KAFKAFI, U. Plant roots: The hidden half. New York: Marcel Dekker, 1996. 1002 p.

WANG, Z.; BURCH, W. H.; MON, P.; JONES, R. S.; MITCHELL, R. J. Accuracy of visible and ultraviolet light for estimating live root proportions with minirhizotron. Ecology, v. 76, p. 2330-2334, 1995.

WILKINS, H.; WAIN, R.L. The role of the root cap in the response of the primary root of Zea mays L. seedlings to white light and to gravity. Planta, v. 123, p. 217-222, 1975.

WHITELY, G.M.; DEXTER, A.R. The behavior of root encountering cracks in soil. I Experimental methods and results. Plant and Soil, v. 77, p. 141-149, 1984.

ZHANG, X.; RENGEL, Z. Gradients of pH, ammonium, and phosphorus between the fertilizer band and wheat roots. Australian Journal of Agricultural Research, v. 50, p. 365-373, 1999. 